\title{
Impact of antibiotics as anthropogenic stressor for influencing bacterial evolutionary process - A review
}

\author{
Sanjib Ghosh \\ Department of Zoology, Jangipur College, Murshidabad, West Bengal, India \\ Corresponding author e-mail: sanjibzoology@gmail.com
}

Received: 2 June 2020 / Accepted: 12 September 2020

\begin{abstract}
A large number of human induced stressors are affecting natural evolutionary process through altering ecosystems and biodiversity. Antibiotics are one of the most commonly excreted pollutants released in environment since last eight decades. Antibiotics can alter genetic orientation of bacterial population and can exert selection pressure for emerging new taxon. In environments like soil and water, antibiotics directly or indirectly may affect many aspects of natural systems like biogeochemical cycles, nitrifications and decomposition process. All these may bring new selection pressure for bacteria not only in community or population level but also in species level.
\end{abstract}

Key words: antibiotics, bacteria, evolution, population, community.

\section{Introduction}

Since industrial revolution human activities has had a great impact on ecosystem and biodiversity of this planet. Directly or indirectly human is acting as one of the most potential driving force that can modify ecosystems as well as biodiversity resulting in vast evolutionary changes in different species around us (Palumbi, 2001). As a hyperkeystone species human dominates over a large number of other keystone species and this hyper-dominance also creates different types of selection pressure on the other component species of the existing biodiversity (Worm \& Paine, 2016). Human activities are causing permanent changes in ecosystems and creating new ecosystems called Anthropogenic Biomes or Anthromes (Ellis, 2011). Rapid evolution has been observed in microbes to vertebrates (Dlugosch \& Parker, 2008) due to anthropogenic causes. Antibiotics (Baquero \& Blazquez, 1997), pesticides (Tabashnik, 1994) and climate change (Parmesan, 2006) are the major anthropogenic stressors that have potential responses to direct evolutionary changes in various ways in different forms of life. In this review I will try to draw a scenario how anthropogenic activities in the form of antibiotics exert evolutionary pressure on microbial communities of different ecosystems and force them to adapt in various selection pressure. Antibiotics act as a potential ecological stressor in the environment that have the potentiality to alter the structure and composition of microbial communities through resistance expansion and ecological function disturbances in the micro-habitat (Ding \& He, 2010).

Antibiotics are used to manage various infectious diseases caused by bacteria in humans, animals, livestock, and aquacultures all over the world (Cycoń et al., 2019). Alexander Fleming (in 1929) discovered penicillin that have inhibitory effect on bacterial cell wall biosynthesis and thus able to stop infectious pathogens like Staphylococcus aureus. Antibiotics are used in large scale since last 80 years to treat a variety of infectious diseases of human and animals. Antibiotics are also used in non-medical purposes like Animal Husbandry and Aquaculture, Bee-keeping, Horticulture, Food preservation, Alcohol production and Boat and hull paint (Meek et al., 2015). 
Use of antibiotics both in medical and non-medical purposes increases rapidly. It is reported that total global antibiotic consumption has been increased by more than 30 percent between 2000 to 2010 (Van Boeckel et al., 2014). In 2010, 63,200 tons of antibiotics were used in animal farming and aquaculture which was more than all human consumption of that year (Van Boeckel et al., 2015). It has been predicted that in 2030 global antibiotics consumption will be $200 \%$ higher than in 2015 (Cycoń et al., 2019).

\section{Classes of antibiotic}

Antibiotics are complex molecules with different functional groups in their chemical structures and are divided into several classes depending on the mechanisms of action, i.e., inhibition of cell wall synthesis, alteration of cell membranes, inhibition of protein synthesis, inhibition of nucleic acids synthesis, competitive antagonism, and antimetabolite activity (Kümmerer, 2009).

Antibiotics are of three types based on their source of production- natural, synthetic and semi-synthetic molecules. Natural antibiotics are produced by bacteria to inhibit or kill other competitor microorganisms. Semi-synthetic compounds are natural antibiotics chemically altered by inserting different groups to improve its effectiveness (Grenni et al., 2018).

\section{Source of Antibiotic in the Environment}

Antibiotics are widely used for treatment of bacterial infections in humans and animals. Moreover, they are used in Animal Husbandry and Aquaculture, Bee-keeping, Horticulture, Food preservation, Alcohol production, Boat and hull paint (Meek et al., 2015). Only a minute portion of

Table 1. Types of antibiotics (Grenni et al., 2018)

\begin{tabular}{|c|c|c|}
\hline Antibiotic class & Mode of action & Example \\
\hline Aminoglycosides & Inhibition of protein synthesis & $\begin{array}{l}\text { Dihydrostreptomycin, Neomycin,Spectinomycin } \\
\text { Streptomycin }\end{array}$ \\
\hline Actinomycines & $\begin{array}{l}\text { Inhibition of the synthesis of } \\
\text { nucleic acids (anticancer drugs) }\end{array}$ & Actinomycin D \\
\hline$\beta$-Lactams & Inhibition of cell wall synthesis & $\begin{array}{l}\text { Amoxicillin, Ampicillin, Cefotaxim, Flucloxacillin, Nafcillin } \\
\text { Oxacillin, Nafcillin, Penicillin G }\end{array}$ \\
\hline Diaminopyrimidine & $\begin{array}{l}\text { Inhibition of purine and } \\
\text { pyrimidine } \\
\text { synthesis }\end{array}$ & Trimethoprim \\
\hline Glycopeptides & $\begin{array}{l}\text { Acting on the wall or membrane } \\
\text { cell }\end{array}$ & Polymyxins, Teicoplanin, Vancomycin \\
\hline Macrolides & $\begin{array}{l}\text { Inhibition of protein synthesis } \\
\text { byreversibly binding to the } 50 \mathrm{~S} \\
\text { ribosomal subunit }\end{array}$ & Azithromycin, Clarithromycin, Erythromycin \\
\hline Nitroimidazole & $\begin{array}{l}\text { Inibition of nucleic acids } \\
\text { synthesis }\end{array}$ & Metronidazole, Tinidazole \\
\hline Phenicols and amphenicols & Inhibition of protein synthesis & Chloramphenicol, Thiamphenicol \\
\hline $\begin{array}{l}\text { Quinolones and } \\
\text { Fluoroquinolones }\end{array}$ & Inhibition of DNA replication & $\begin{array}{l}\text { Ciprofloxacin, Enrofloxacin, Nalidixic acid } \\
\text { Ofloxacin }\end{array}$ \\
\hline Rifamycins & $\begin{array}{l}\text { Inibition of nucleic acids } \\
\text { synthesis }\end{array}$ & $\begin{array}{l}\text { Rifampicin } \\
\text { Rifapentine }\end{array}$ \\
\hline Sulfonamides & $\begin{array}{l}\text { Inhibition of the folic acid } \\
\text { synthesis }\end{array}$ & $\begin{array}{l}\text { Sulfachloropyridazine,Sulfanilamide } \\
\text { Sulfadimethoxine,Sulfathiazole }\end{array}$ \\
\hline Tetracyclines & Inhibition of the protein synthesis & $\begin{array}{l}\text { Chlortetracycline, Doxycycline } \\
\text { Oxytetracycline, Tetracycline }\end{array}$ \\
\hline
\end{tabular}


the administered antibiotics are metabolized in human and animal bodies and rest of the drugs are excreted out and discharged into water and soil through municipal wastewater, animal manure, sewage sludge, and biosolids (Bouki et al., 2013; Daghrir \& Drogui, 2013; Wu et al., 2014). It has been reported that $75-80 \%$ of tetracyclines, $50-90 \%$ of erythromycin and $60 \%$ of lincomycin are excreted in urine and feces (Kumar et al., 2005; Sarmah et al., 2006). The concentrations of antibiotic residues in manure, sewage sludge and biosolids show large variations. Tetracyclines are the most frequently reported antibiotics found in manure (Pan et al., 2011; Chen et al., 2012; Massé et al., 2014). Other groups of antibiotics with considerable concentrations found in manure are fluoroquinolones (Zhao et al., 2010; Van Doorslaer et al., 2014) and sulfonamides (Martínez-Carballo et al., 2007).

\section{Fate of Antibiotics in the Environment}

In the environment, antibiotics have to face different biotic and abiotic processes like transformation and degradation (Reichel et al., 2013; Cui et al., 2014; Manzetti \& Ghisi, 2014; Duan et al., 2017). Molecular structure and physicochemical properties of antibiotics govern their transforma- tion and degradation processes (Thiele-Bruhn, 2003; Pan $\& \mathrm{Chu}, 2017)$. Degradation process of antibiotics in natural environment is controlled by various biotic and abiotic factors. For this reason variation is found in the rate of degradation of different groups of antibiotics. Long-term persistence of azithromycin, ofloxacin, and tetracycline in soils (with half-lives of 408-3466 days, 866-1733days and 578 days, respectively) were reported by Walters et al. (2010).

\section{Impact of Antibiotics}

Uncontrolled usage of antibiotics imposes strong selection pressure for resistance development. Emergence of resistance results in adaptation (Sultan et al., 2018). Both antibiotics and antibiotic resistant genes (ARG) directly or indirectly can affect bacterial community (Grenni et al., 2018) structure. Here some direct impact of antibiotics on different aspects of bacterial ecosystem and biodiversity are discussed in short.

Table 2. Maximum reported concentrations of selected antibiotics detected in manure and sewage sludge (Cycoń et al., 2019)

a) MANURE, $\mu \mathrm{g} / \mathrm{kg}$

\begin{tabular}{llll}
\hline Class & Antibiotics & Concentration & Reference \\
\hline Fluoroquinolones & Ciprofloxacin & 45,000 & Zhao et al., 2010 \\
& Enrofloxacin & 1,420 & \\
& Fleroxacin & 99,000 & \\
& Norfloxacin & 225,000 & Martínez-Carballo \\
Sulfonamides & et al., 2007 \\
& Sulfadiazine & 91,000 & Massé et al., 2014 \\
Tetracyclines & Chlortetracycline & & Pan et al., 2012 2011 \\
& Oxytetracycline & 764,000 & 354,000 \\
\end{tabular}

b) SEWAGE SLUDGE, $\mu \mathrm{g} / \mathrm{kg}$ dry weihgt

\begin{tabular}{llll}
\hline Class & Antibiotics & Concentration & Reference \\
\hline Diaminopyrimidines & Trimethoprim & 133 & Göbel et al., 2005 \\
Macrolides & Azithromycin & $1.3-158$ & $\begin{array}{l}\text { Göbel et al., 2005; Li et al., } \\
\text { Sulfonamides }\end{array}$ \\
& Sulfadimethoxine & $0-20(22.7)$ & $\begin{array}{l}\text { Lillenberg et al., 2010; Li } \\
\text { et al., 2013 }\end{array}$ \\
\hline
\end{tabular}




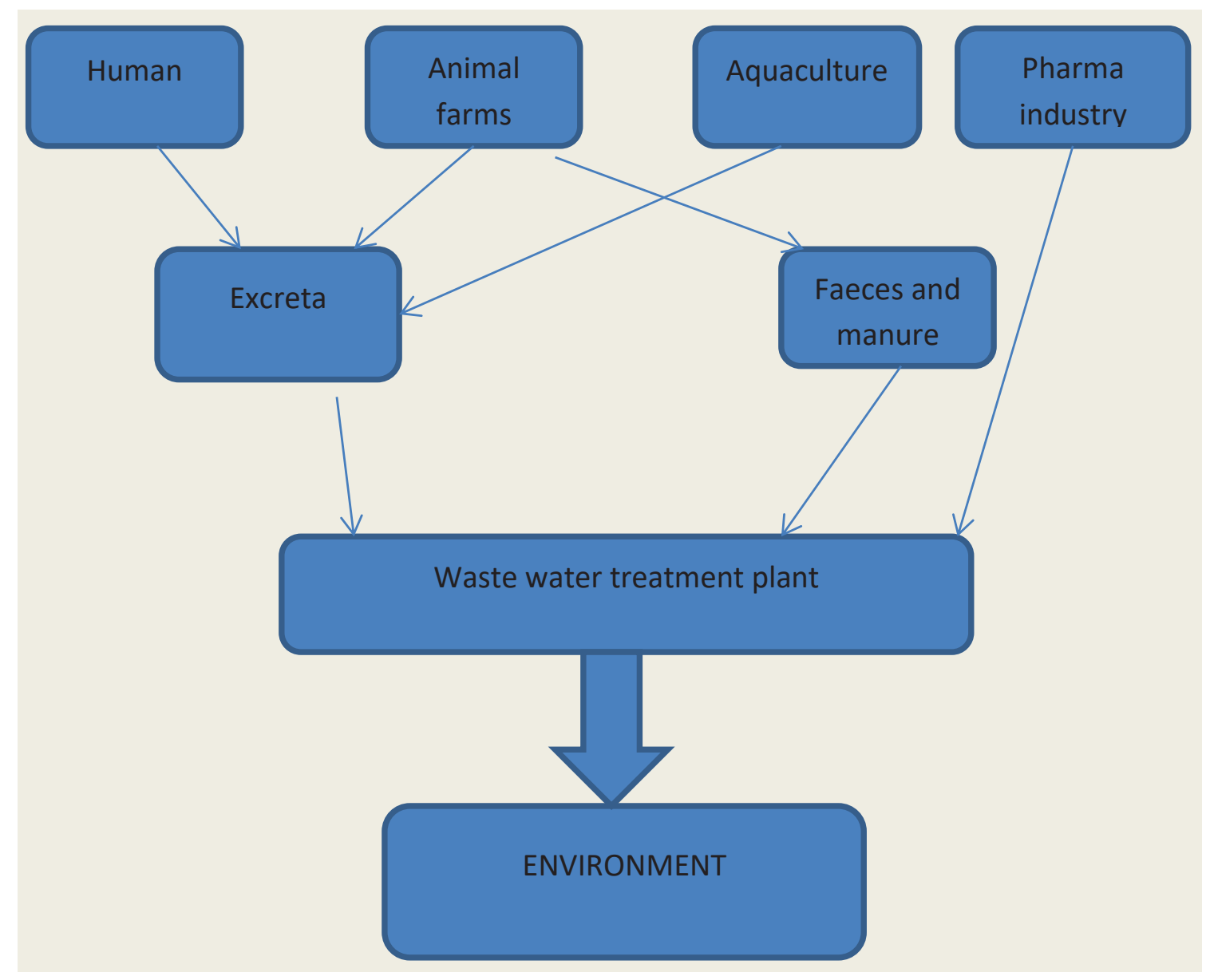

Figure 1. Fate of antibiotics in the environment

\subsection{Bacterial ecosystem}

Bacterial diversity is mostly governed by their ecosystems. Soil and aquatic ecosystems are more or less loaded with antibiotics and have severe consequences in terms of habitat modification and interaction with other living forms. Soil plays a pivotal role in ecosystems serving the primary nutrient source and habitat for plants and other organisms. Soil receives a large portion of excreted antibiotics through application of manure and sewage sludge as fertilizers in agricultural fields and for this reason soil acts as hotspots for antibiotics to affect its indigenous microbial populations (Thiele-Bruhn \& Beck, 2005). Higher density of bacteria in the soil ecosystem may involve in genetic exchanges, which could result in the development of microbial resistance in the presence of antibiotics (Murray, 1997). Two studies on sulfadiazine (Kotzerke et al., 2008; Schauss et al., 2009) have demonstrated the effects of antibiotics on soil nitrification and denitrification process- es. Various antibiotics like ciprofloxacin (Naslund et al., 2008), sulfadiazine (Zielezny et al., 2006; Kotzerke et al., 2008) and tylosin (Müller et al., 2002; Demoling \& Bååth, 2008) have been reported to affect soil biomass production soil respiration rates. Nitrogen transformation process has been studied by Tomlinso et al. (1966). They reported that streptomycin (at $400 \mathrm{mg} / \mathrm{L}$ ) was required to achieve $75 \%$ inhibition of ammonia oxidation in activated sludge in $2 \sim 4$ h. It has also been reported that antibiotics such as oxytetracycline inhibit nitrification process in surface water (Klaver \& Matthews, 1994). Methanogenesis has been reported to respond to antibiotics like sulfamethoxazole and ofloxacin (Fountoulakis et al., 2004).

\subsection{Bacterial community structure}

Microbial biodiversity plays an important role in the maintenance of biological processes in water and soil. Most biogeochemical cycles are exclusively regulated by mi- 
croorganisms. Antibiotics can act as an ecological stressor in the environment by driving changes in the structure of natural bacterial communities through disappearance of some bacterial groups (Allen et al., 2010). The effects can be found even in non-target organisms with important ecological functions (Pallecchi et al., 2008; Martinez, 2009). Many studies have revealed that the presence of antibiotics may result in a reduction in microbial biodiversity. Moreover, they can influence the growth and enzyme activities of bacterial communities and ultimately ecological functions such as biomass production and nutrient transformation, leading to loss of functional stability (Martinez, 2009; Koike et al., 2007; Pauwels \& Verstraete, 2006; Święciło \& Zych-Wężyk, 2013). Antibiotics may have a selective effect on various microbial groups that can alter the relative abundance of different bacterial species and interfere in interactions between different species (Grenni et al., 2018). Various ecological processes like nitrogen transformation, methanogenesis, sulfate reduction, nutrient cycling and organic matter degradation may be changed due to the presence of different groups of antibiotics in natural environment that individually or altogether may result in severe alteration in the structure and composition of bacterial community (Roose-Amsaleg \& Laverman, 2016). Sulfonamides have been reported to induce a change in microbial diversity by reducing not only microbial biomass, but also affecting the relationship between bacteria and fungi (Underwood et al., 2011).

\subsection{Bacterial population structure}

Antibiotics can affect the structure and composition of bacterial populations. Any bacterial species has specific type of susceptibility to any given antibiotic (Olivares et al., 2013; Cox \& Wright, 2013; Girgis et al., 2009). For any given concentration of antibiotic, a part of the population present in the micro biota (the most susceptible one) will be inhibited and another part will consequently increase their number. It is reported by several workers that a strong stressor (such as the presence of an antibiotic) will reduce diversity (Abeles et al., 2016; Cleary et al., 2016). Presence of mild concentrations of antibiotics may produce an apparent increase in biodiversity by the emergence of new taxons whose presence was very little before antibiotic stress (Zhang et al., 2015). The most significant studies of the effect of antibiotics on the composition of the microbiota have been performed through studying the gut microbiota of humans and other experimental mammal models (Looft \& Allen, 2012; Jernberg et al., 2010; Forslund et al., 2013; Robinson \& Young, 2010). Most of the researchers observed some misbalances in the bacterial composition upon treatment with antibiotics. Once treatment ends, a recovery of the composition of the microbiome is observed after some time. Recent evidences show that the bacte- rial groups present in the microbiome before and after the treatment are not same (Raymond et al., 2016). This means that while the overall structure of the population remains constant, the overall genomic content largely varies (Raymond et al., 2016).

\subsection{Bacterial genetic system}

Genetic diversity in bacterial population may be increased due to exposure to low levels of antibiotics through activation of the bacterial SOS response which in turn may result in an increased rate of mutation throughout the genome (Foster, 2007; Andersson \& Hughes, 2014). Antibiotics were also found to increase the horizontal transfer of genetic material between bacteria either by conjugation (Maiques et al., 2006) or by increasing competence resulting in the uptake of extracellular DNA (Slager et al., 2014). A large number of antibiotics were found to affect the process of gene regulation at the transcription level (Davies et al., 2006; Goh et al., 2002), either via direct binding or through other regulatory mechanisms such as riboswitches (Blount \& Breaker, 2006) and quorum sensing (Rémy et al., 2018), resulting in increased phenotypic variability. Together, these mechanisms increase the available pool of genetic and phenotypic diversity in bacterial populations exposed to antibiotic.



Figure 2. Impact of antibiotics on bacterial Genetic system 


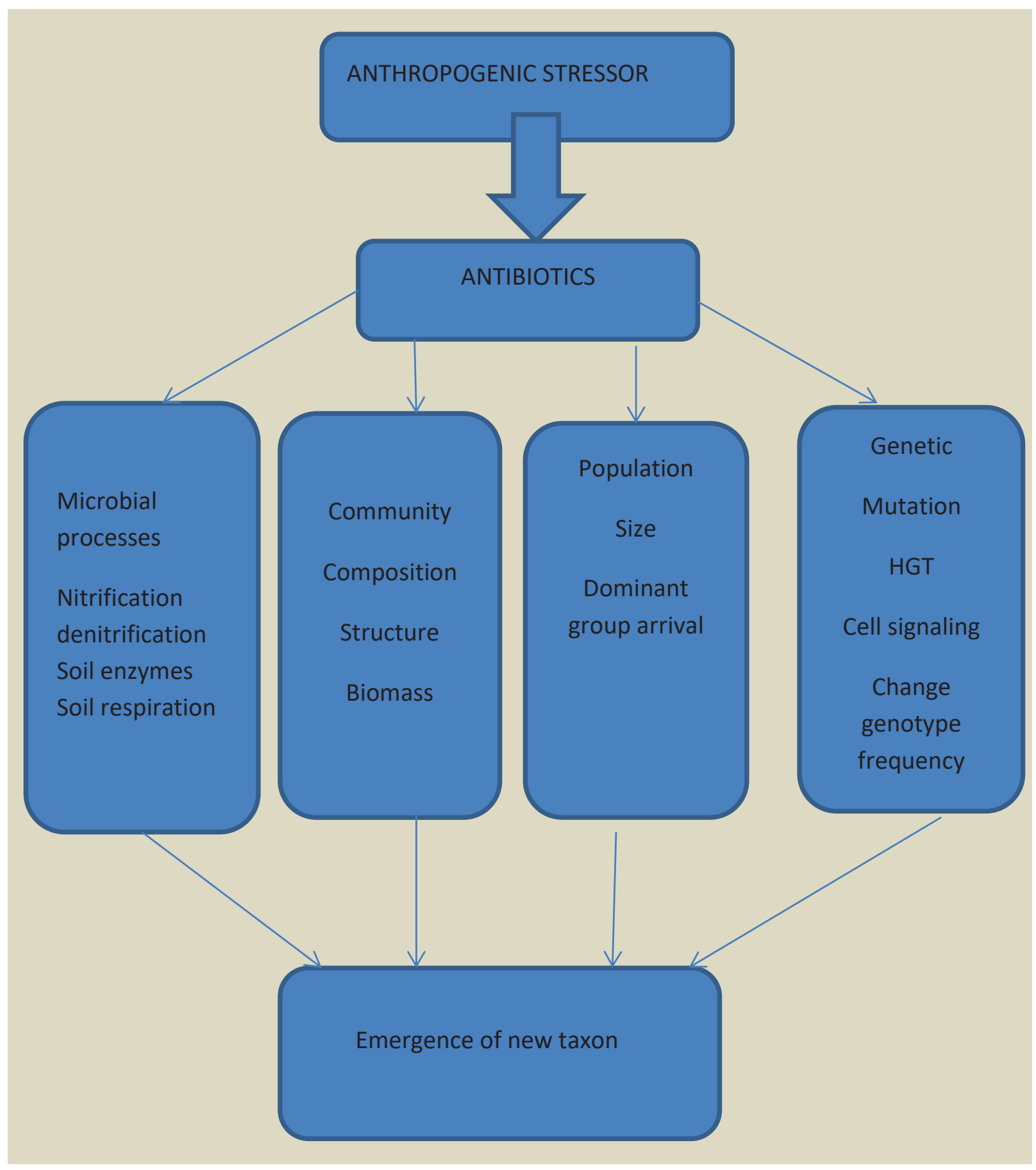

Figure 3. How antibiotics influence emergence of new Taxa

\section{Discussion}

Antibiotics are naturally produced compounds and most of the bacterial populations are well adapted to the presence of the natural concentrations of these antimicrobials
(Kelsic et al., 2015). Antibiotics are most successful compounds ever discovered to treat infectious diseases caused by bacterial infection. Since last eight decades we have increased the usage of this magical drugs in various medical purposes as well as in non-medical purposes. Uncon- 
trolled and unethical use of antibiotics are now a critical concern of health care providers as most of the antibiotics become resistant to their target organisms. Huge amount of antibiotics are now documented to present in different ecosystems like soil and water. Now a days another voices from the side of ecologists and environmentalists are raised as a large number of studies and reports are coming in light evidenced with severe impacts of antibiotics beyond their target organisms. The selective pressures imposed by antibiotic pollution can impact on the evolutionary dynamics observed in microbial populations in different ways (Martínez, 2017).

Different bacterial species or lineages within a species harbor phenotypic heterogeneity in their response to antibiotics. Certain bacterial populations have been reported to exhibit different levels of tolerance to antibiotics due to changes in gene expression or fluctuations in critical physiological traits (Sanchez-Romero \& Casadesus, 2013; Sanchez-Romero \& Dunlop, 2018). Bacteria and fungi inhabiting soil and aquatic environments are not only the foundation of the most diverse and densely populated ecosystems on Earth (Lozupone \& Knight, 2007; Caporaso et al., 2011) but are also crucial for the performance of important ecological processes like nutrient cycling, decomposition, and primary productivity (Torsvik et al., 2002; Gibbons \& Gilbert, 2015; Van Bruggen et al., 2019). Selective pressures associated with antibiotic pollution can act on the overall microbial community composition by reducing taxa diversity or by shifting microbial composition. Antibiotic exposure tends to favour an increase in Gram-negative bacteria as opposed to Gram-positive bacteria. The latter showing increased susceptibility to antibiotics due to the absence of an outer cell membrane (Delcour, 2009). Exposure to antibiotics may thus result in the loss of key microbial taxa with important ecological roles. Antibiotic pollution in aquatic environments was found to reduce overall microbial diversity, including taxa responsible for carbon cycling and primary productivity (Grenni et al., 2018; Eckert et al., 2019; Ding \& He, 2010). Similarly, the presence of antibiotics in soil was found to alter microbial community structure, leading to a loss of biomass and a reduction in microbial activity including nitrification, denitrification, and respiration (Thiele-Bruhn \& Beck, 2005; Westergaard et al., 2001; Cycoń et al., 2019). Moreover, antibiotics can also affect bacterial enzyme activity, including dehydrogenases, phosphatases, and ureases, which are considered important indicators of soil activity (Cycoń et al., 2019). Finally, antibiotic disruption of microbial communities can also lead to an increased abundance of parasites and pathogens in both soil and water environments. For example, the presence of antibiotic pollution in aquatic environment was shown to lead to an increase frequency of toxic $\mathrm{Cy}$ anobacteria species, causing eutrophication in freshwater environments (Drury et al., 2013).

\section{Conclusions}

It can be summarized that antibiotic load on environment is created by human and the effect of antibiotic is continuous alteration in genetic combinations of bacterial populations resulting in selection of new taxon in different ecosystems. Global impact of antibiotics may be extended onto their beneficial interactions with plants and organisms. Alteration in the composition of bacterial community may create selection pressure for other higher organisms too. Though it needs more study and data, theoretically it can be hypothesized that anthropogenic activities like imposing antibiotic load in environment may alter the global evolutionary process in bacterial population to some extent.

\section{References}

Abeles S.R., Jones M.B., Santiago-Rodriguez T.M., Ly M., Klitgord N., Yooseph S., Nelson K.E. \& Pride D.T., 2016, Microbial diversity in individuals and their household contacts following typical antibiotic courses. Microbiome 4(1): 39.

Allen H.K., Donato J., Wang H.H., Cloud-Hansen K.A., Davies J. \& Handelsman J., 2010, Call of the wild: antibiotic resistance genes in natural environments. Nat. Rev. Microbiol. 8: 251-259.

Andersson D.I. \& Hughes D., 2014,Microbiological effects of sublethal levels of antibiotics. Nat. Rev. Microbiol. 12(7): 465-478.

Baquero F. \& Blazquez J., 1997, Evolution of antibiotic resistance. Trends Ecol. Evol. 12: 482-87.

Blount K.F. \& Breaker R.R., 2006, Riboswitches as antibacterial drug targets. Nat. Biotechnol. 24: 1558-1564.

Bouki C., Venieri D. \& Diamadopoulos E., 2013, Detection and fate of antibiotic resistant bacteria in wastewater treatment plants: a review. Ecotoxicol. Environ. Saf. 91: 1-9.

Caporaso J.G., Lauber C.L., Walters W.A., Berg-Lyons D., Lozupone C.A., Turnbaugh P.J., Fierer N. \& Knight R., 2011, Global patterns of 16S rRNA diversity at a depth of millions of sequences per sample. Proc. Natl. Acad. Sci. USA 108: 4516-4522.

Chen Y.S., Zhang H.B., Luo Y.M. \& Song J., 2012, Occurrence and assessment of veterinary antibiotics in swine manures: a case study in East China. Chinese Sci. Bull. 57: 606-614.

Cleary D.W., Bishop A. H., Zhang L., Topp E., Wellington E.M.H. \& Gaze W.H., 2016, Long-term antibiotic exposure in soil is associated with changes in microbial community structure and prevalence of class 1 integrons. FEMS Microbiol. Ecol. 92(10): fiw159. Doi: 10.1093/femsec/fiw 159 
Cox G. \& Wright G.D., 2013, Intrinsic antibiotic resistance: mechanisms, origins, challenges and solutions. Int. J. Med. Microbiol. 303(6-7): 287-92.

Cui H., Wang S.-P., Fu J., Zhou Z.-Q., Zhang N. \& Guo L., 2014, Influence of ciprofloxacin on microbial community structure and function in soils. Biol. Fertil. Soils 50: 939-947.

Cycoń M., Mrozik A. \& Piotrowska-Seget Z., 2019, Antibiotics in the Soil Environment-Degradation and Their Impact on Microbial Activity and Diversity. Front.Microbiol. 10: 338. Doi: 10.3389/fmicb.2019.00338

Daghrir R. \& Drogui P., 2013, Tetracycline antibiotics in the environment: a review. Environ. Chem. Lett. 11: 209-227.

Davies J., Spiegelman G.B. \& Yim G., 2006, The world of subinhibitory antibiotic concentrations. Curr. Opin. Microbiol. 9: 445-453.

Delcour A.H., 2009, Outer membrane permeability and antibiotic resistance. Biochim. Biophys. Acta Proteins Proteom. 1794: 808-816.

Demoling L.A. \& Bååth E., 2008, No long-term persistence of bacterial pollution-induced community tolerance in tylosin-polluted soil. Environ. Sci. Technol. 42: 6917-6921

Ding C. \& He J., 2010, Effect of antibiotics in the environment on microbial populations. Appl. Microbiol. Biotechnol. 87: 925-941.

Dlugosch K.M. \& Parker I.M., 2008, Invading populations of an ornamental shrub show rapid life history evolution despite genetic bottlenecks. Ecol. Lett. 11: 701-9.

Drury B., Scott J., Rosi-Marshall E.J. \& Kelly J.J., 2013,Triclosan exposure increases triclosan resistance and influences taxonomic composition of benthic bacterial communities. Environ. Sci. Technol. 47: 8923-8930

Duan M., Li H., Gu J., Tuo X., SunW., Qian X. \& Wang X., 2017, Effects of biochar on reducing the abundance of oxytetracycline, antibiotic resistance genes, and human pathogenic bacteria in soil and lettuce. Environ Pollut. 224: 787-795.

Eckert E.M., Quero G.M., Di Cesare A., Manfredini G., Mapelli F., Borin S., Fontaneto D., Luna G.M. \& Corno G., 2019, Antibiotic disturbance affects aquatic microbial community composition and food web interactions but not community resilience. Mol. Ecol. 28: 1170-1182.

Ellis E.C., 2011, Anthropogenic transformation of the terrestrial biosphere. Philos. Trans. R. Soc. A: Math. Phys. Eng. Sci. 369: 1010-1035.

Forslund K., Sunagawa S., Kultima J.R., Mende D.R., Arumugam M., Typas A. \& Bork P., 2013, Countryspecific antibiotic use practices impact the human gut resistome. Genome Res. 23(7): 1163-1169.

Foster P., 2007, Stress-induced mutagenesis in bacteria. Crit. Rev. Biochem. Mol. Biol. 42: 373-397.
Fountoulakis M.S., Drillia P., Stamatelatou K. \& Lyberatos G., 2004, Toxic effect of pharmaceuticals on methanogenesis. Water Sci. Technol. 50: 335-340.

Gibbons S.M. \& Gilbert J.A., 2015, Microbial diversityexploration of natural ecosystems and microbiomes. Curr.Opin. Genet. Dev. 35:66-72.

Girgis H.S., Hottes A.K. \& Tavazoie S., 2009, Genetic architecture of intrinsic antibiotic susceptibility. PLoS One4(5): e5629.

Göbel A., Thomsen A., McArdell C.S., Alder A.C, Giger W., TheissN., Löffler D. \& Ternes T.A., 2005, Extraction and determination of sulfonamides, macrolides, and trimethoprim in sewage sludge. J. Chromatogr. A 1085: 179-189.

Goh E.-B., Yim G.,TsuiW., McClure J., Surette M.G. \& Davies J., 2002, Transcriptional modulation of bacterial gene expression by subinhibitory concentrations of antibiotics. Proc. Natl. Acad. Sci. USA 99: 1702517030.

Grenni P., Ancona V. \& Barra Caracciolo A., 2018. Ecological effects of antibiotics on natural ecosystems: a review. Microchem. J. 136: 25-39.

Jernberg C., Löfmark S., Edlund C. \& Jansson J.K., 2010, Long-term impacts of antibiotic exposure on the human intestinal microbiota. Microbiology 156(1): 3216-23.

Kelsic E.D., Zhao J., Vetsigian K. \& Kishony R., 2015, Counteraction of antibiotic production and degradation stabilizes microbial communities. Nature 521(7553): 516-519.

Klaver A.L. \& Matthews R.A., 1994, Effects of oxytetracycline on nitrification in a model aquatic system. Aquaculture 123: 237-247.

Koike S., Krapac I.G., Oliver H.D., Yannarell A.C., CheeSanford J.C., Aminov R.I. \& Mackie R.I., 2007, Monitoring and source tracking of tetracycline resistance genes in lagoons and groundwater adjacent to swine production facilities over a 3 -year period. Appl. Environ. Microbiol. 73: 4813-4823.

Kotzerke A., Sharma S., Schauss K., Heuer H., ThieleBruhn S., Smalla K., Wilke B.M. \& Schloter M., 2008, Alterations in soil microbial activity and N-transformation processes due to sulfadiazine loadsin pig-manure. Environ.Pollut. 153: 315-322.

Kumar K., Gupta C.S., Chander Y. \& Singh A.K., 2005, Antibiotic use in agriculture and its impact on the terrestrial environment. Adv. Agron. 87: 1-54.

Kümmerer K., 2009, Antibiotics in the aquatic environment - a review_part I. Chemosphere 75: 417-434.

Li W., Shi Y., Gao L., Liu J. \& Cai Y., 2013, Occurrence, distribution and potential affecting factors of antibiotics in sewage sludge of wastewater treatment plants in China. Sci. Tot. Environ. 445-446: 306-313.

Lillenberg M., Yurchenko S., Kipper K., Herodes K., Pihl V., Lõhmus R., Ivask M., Kuu A., Kutti S., Litvin S.V. 
\& Nei L., 2010, Presence of fluoroquinolones and sulfonamides in urban sewage sludge and their degradation as a result of composting. Int. J. Environ. Sci. Technol. 7: 307-312.

Looft T. \& Allen H.K., 2012, Collateral effects of antibiotics on mammalian gut microbiomes. Gut Microbes 3(5): 463-467.

Lozupone C.A. \& Knight R., 2007, Global patterns in bacterial diversity. Proc. Natl. Acad. Sci. USA 104: 11436-11440.

Maiques E., Úbeda C., Campoy S., Salvador N., Lasa Í., Novick R.P., Barbé J. \& Penadés J.R., 2006, Betalactam antibiotics induce the SOS response and horizontal transfer of virulence factors in Staphylococcus aureus. J. Bacteriol. 188: 2726-2729.

Manzetti S. \& Ghisi R., 2014, The environmental release and fate of antibiotics. Mar. Pollut. Bull. 79: 7-15.

Martinez J.L., 2009, Environmental pollution by antibiotics and by antibiotic resistance determinants. Environ. Pollut. 157: 2893-2902.

Martínez J.L., 2017, Effect of antibiotics on bacterial populations: A multi-hierarchical selection process. F1000Research 6(F1000 Faculty Rev.): 51.

Martínez-Carballo E., González-Barreiro C., Scharf S. \& Gans O., 2007, Environmental monitoring study of selected veterinary antibiotics in animal manure and soils in Austria. Environ. Pollut. 148: 570-579.

Massé D.I., Saady N.M.C. \& Gilbert Y., 2014, Potential of biological processes to eliminate antibiotics in livestock manure: an overview. Animals 4: 146-163.

Meek R.W., Vyas H. \& Piddock L.J.V., 2015, Nonmedical Uses of Antibiotics: Time to Restrict Their Use? PLoS Biol. 13(10): e1002266.

Müller A.K., Westergaard K., Christensen S. \& Sørensen S.J., 2002, The diversity and function of soil microbial communities exposed to different disturbances. Microb. Ecol. 44: 49-58.

Murray B.E., 1997, Antibiotic resistance. Adv. Intern. Med. 42: 339-367.

Naslund J., Hedman J.E. \& Agestrand C., 2008, Effects of the antibiotic ciprofloxacin on the bacterial community structure and degradation of pyrene in marine sediment. Aquat. Toxicol. 90: 223-227.

Olivares J., Bernardini A., Garcia-Leon G., Corona F., Sanchez M.B. \& Martinez J.L., 2013, The intrinsic resistome of bacterial pathogens. Front.Microbiol. 30(4): 103. Doi: 10.3389/fmicb.2013.00103

Pallecchi L., Bartoloni A., Paradisi F. \& Rossolini G.M., 2008, Antibiotic resistance in the absence of antimicrobial use: mechanisms and implications. Expert Rev. Anti-Infect. Ther. 6: 725-732.

Palumbi S.R., 2001, Humans as the world's greatest evolutionary force. Science 293: 1786-1790.
Pan X., Qiang Z., Ben W. \& Chen M., 2011, Residual veterinary antibiotics in swine manure Chemosphere 84 : 695-700.

Pan M. \& Chu L.M., 2017, Leaching behavior of veterinary antibiotics in animal manure-applied soils. Sci. Total Environ. 579: 466-473.

Parmesan C., 2006, Ecological and evolutionary responses to recent climate change. Annu. Rev. Ecol. Evol. Syst. 37: 637-669.

Pauwels B. \& Verstraete W., 2006, The treatment of hospital wastewater: an appraisal. J. Water Health 4: 405-416.

Raymond F., Deraspe M., Boissinot M., Bergeron M.G. \& Corbeil J., 2016, Partial recovery of microbiomes after antibiotic treatment. Gut Microbes 7(5): 428-434.

Reichel R., Rosendahl I., Peeters E.T.H.M., Focks A., Groeneweg J., Bierl R., Schlichting A., Amelung W. \& Thiele-Bruhn S., 2013, Effects of slurry from sulfadiazine- (SDZ) and difloxacin- (DIF) medicated pigs on the structural diversity of microorganisms in bulk and rhizosphere soil. Soil Biol. Biochem. 62: 82-91.

Rémy B., Mion S., Plener L., Elias M., Chabrière E. \& Daudé D., 2018, Interference in bacterial quorum sensing: A biopharmaceutical perspective. Front. Pharmacol. 9: 203.

Robinson C.J. \& Young V.B., 2010, Antibiotic administration alters the community structure of the gastrointestinal microbiota. Gut Microbes 1(4): 279-84.

Roose-Amsaleg C. \& Laverman A.M., 2016, Do antibiotics have environmental side-effects? Impact of synthetic antibiotics on biogeochemical processes. Environ. Sci. Pollut. Res. 23: 4000-4012.

Sanchez-Romero M.A. \& Casadesus J., 2013, Contribution of phenotypic heterogeneity to adaptive antibiotic resistance. Proc. Natl. Acad. Sci. USA 111: 355-360.

Sanchez-Romero I. \& Dunlop M.J., 2018, Heterogeneity in efflux pump expression predisposes antibiotic-resistant cells to mutation. Science 362: 686-690.

Sarmah A.K., Meyer M.T. \& Boxall A.B.A., 2006, A global perspective on the use, sales, exposure pathways, occurrence, fate and effects of veterinary antibiotics (VAs) in the environment. Chemosphere 65: 725-759.

Schauss K., Focks A., Leininger S., Kotzerke A., Heuer H., Thiele-Bruhn S., Sharma S., Wilke B.M., Matthies M., Smalla K., Munch J.C., Amelung W., Kaupenjohann M., Schloter M. \& Schleper C., 2009, Dynamics and functional relevance of ammonia-oxidizing archaea in two agricultural soils. Environ. Microbiol. 11: 446-456.

Slager J., Kjos M., Attaiech L. \& Veening J.W., 2014, Antibiotic-induced replication stress triggers bacterial competence by increasing gene dosage near the origin. Cell 157: 395-406.

Sultan I., Rahman S., Jan A.T., Siddiqui M.T., Mondal A.H. \& Haq Q.M.R., 2018, Antibiotics, Resistome and Re- 
sistance Mechanisms: A Bacterial Perspective. Front. Microbiol. 9: 2066. Doi: 10.3389/fmicb.2018.02066

Święciło A. \& Zych-Wężyk I., 2013, Bacterial stress response as an adaptation to life in a soil environment. Pol. J. Environ. Stud. 22: 1577-1587.

Tabashnik B.E., 1994, Evolution of resistance to Bacillus thuringiensis. Annu. Rev. Entomol. 39: 47-79.

Thiele-Bruhn S., 2003, Pharmaceutical antibiotic compounds in soils - a review. J. Plant Nutr. Soil Sci. 166 145-167.

Thiele-Bruhn S. \& Beck I.C., 2005, Effects of sulfonamide and tetracycline antibiotics on soil microbial activity and microbial biomass. Chemosphere 59: 457-465.

Tomlinso T.G., Boon A.G. \& Trotman C.A.N., 1966, Inhibition of nitrification in activated sludge process of sewage disposal. J. Appl. Bacteriol. 29: 266-291.

Torsvik V., Øvreås L. \& Øvreas L., 2002, Microbial Diversity and Function in Soil: From Genes to Ecosystems. Curr. Opin. Microbiol. 5: 240-245.

Underwood J.C., Harvey R.W., Metge D.W., Repert D.A., Baumgartner L.K., Smith R.L., Roane T.M. \& Barber L., 2011, Effects of the antimicrobial sulfamethoxazole on groundwater bacterial enrichment. Environ. Sci. Technol. 45: 3096-3101.

Van Boeckel T.P., Gandra S., Ashok A., Caudron Q., Grenfell B.T., Levin S.A. \& Laxminarayan R., 2014, Global Antibiotic Consumption 2000 to 2010: An Analysis of National Pharmaceutical Sales Data. The Lancet Infectious Diseases 3099(14): 1-9.

Van Boeckel T.P., Brower C., Gilbert M., Grenfell B.T., Levin S., Robinson T.P., Teillant A. \& Laxminarayan R., 2015, Global Trends in Antimicrobial Use in Food Animals. Proc. Natl Acad. of Sci. USA 112(18): 56495654.

Van Bruggen A.H.C., Goss E.M., Havelaar A., Van Diepeningen A.D., Finckh M.R. \& Morris J.G., 2019, One
Health - Cycling of diverse microbial communities as a connecting force for soil, plant, animal, human and ecosystem health. Sci. Total Environ. 664: 927-937.

Van Doorslaer X., Dewulf J., Van Langenhove H. \& Demeestere K., 2014, Fluoroquinolone antibiotics: an emerging class of environmental micropollutants. Sci. Total Environ. 500-501: 250-269.

Walters E., McClellan K. \& Halden R.U., 2010, Occurrence and loss over three years of 72 pharmaceuticals and personal care products from biosolids-soil mixtures in outdoor mesocosms. Water Res. 44: 6011-6020.

Westergaard K., Müller A.K., Christensen S., Bloem J. \& Sørensen S.J., 2001, Effects of tylosin as a disturbance on the soil microbial community. Soil Biol. Biochem. 33: 2061-2071.

Worm B. \& Paine R.T., 2016, Humans as a Hyper keystone Species. Trends Ecol. Evol. 31: 600-607.

Wu X.-L., Xiang L., Yan Q.-Y., Jiang Y.-N., Li Y.-W., Huang X.-P., Li H., Cai Q.-Y. \& Mo C.H., 2014, Distribution and risk assessment of quinolone antibiotics in the soils from organic vegetable farms of a subtropical city, Southern China. Sci. Total Environ. 487: 399-406.

Zhang Y., Tian Z. \& Liu M., 2015, High Concentrations of the Antibiotic Spiramycin in Wastewater Lead to High Abundance of Ammonia-Oxidizing Archaea in Nitrifying Populations. Environ. Sci. Technol. 49(15): 9124-32.

Zhao L., Dong Y.H. \& Wang H., 2010, Residues of veterinary antibiotics in manures from feedlot livestock in eight provinces of China. Sci. Total Environ. 408: 1069-1075.

Zielezny Y., Groeneweg J., Vereecken H. \& Tappe W., 2006, Impact of sulfadiazine and chlorotetracycline on soil bacterial community structure and respiratory activity. Soil Biol. Biochem. 38: 2372-2380. 


\title{
Kinetics of $\mathrm{Cd}$, Co and Ni Adsorption from Wastewater using Red and Black Tea Leaf Blend as a Bio-adsorbent
}

\author{
Parisa Ziarati', Pavlo Kozub ${ }^{2}$, Sergij Vambol ${ }^{3}$, Viola Vambol ${ }^{4, *}$, Nadeem A. Khan ${ }^{5}$, \\ Svetlana Kozub ${ }^{6}$, Sepideh Tajik ${ }^{1}$
}
${ }^{1}$ Nutrition and Food Sciences Research Centre, Tehran Medical Sciences, Islamic Azad University, Tehran, Iran
${ }^{2}$ Department of Natural Science, Kharkiv National University of Radio Electronics, Kharkiv, Ukraine,
${ }^{3}$ Life Safety and Law Department, Kharkiv Petro Vasylenko National Technical University of Agriculture, Kharkiv, Ukraine
${ }^{4}$ Educational and Scientific Department of Safety and Occupational Health, Public Agency "National Scientific and Research Institute of Industrial Safety and Occupational Safety and Health", Kyiv, Ukraine
${ }^{5}$ Department Civil Engineering, Jamia Millia Islamia, New Delhi, India
${ }^{6}$ Department of Medical and Bioorganic Chemistry, Kharkiv National Medical University, Kharkiv, Ukraine
*corresponding author e-mail: violavambol@gmail.com

Received: 29 May 2020 / Accepted: 27 August 2020

\begin{abstract}
Every year there is deterioration in water quality. This is due to human activity. The current environmental strategies of many countries motivate the scientific community to develop reliable, economically viable and environmentally friendly technologies that are able to remove pollutants from the environment, including water. The study purpose is to determine of influence regularity of the bio-adsorbent composition and amount, which consists of red and black tea leaves mixture, on the Cd, Co and Ni adsorption process based on experimental data. As well as determine the most rational bio-adsorbent dose and the necessary red and black tea dose in bio-adsorbent to achieve MPC of heavy metals, with which process duration will be minimal. Initially, to study the adsorption process kinetics, the nature of the curve that describes the obtained experimental values was visually analyzed. To determine the adsorption process kinetic regularity, which most adequately and reliably describes the experimental data and to determine the values of the coefficients in the exponential regularity, the least squares method was used. It was observed that for $\mathrm{Cd}$ and $\mathrm{Co}$, an increase in the black and red tea amount leads to a drastic reduction of the adsorption process time (up to 10 times); while for Ni the black tea addition slows down the adsorption process. Ni adsorption is the most complex and for certain bio-adsorbent composition values, complete Ni removal cannot be achieved in a technologically reasonable adsorption time. The technological process of Cd, $\mathrm{Co}$ and $\mathrm{Ni}$ adsorption can be expedient, if it is carried out in several stages with optimal red and black tea amounts for each of the metals. Adsorption process kinetic regularity, which was determined, can be used to calculate of adsorption process technological parameters in values wide range.
\end{abstract}

Keywords: kinetic regularity of adsorption, bio-adsorbent dose, leaves, heavy metals, wastewater.

\section{Introduction}

Every year there is deterioration in water quality. This is due to human activity (Kipigroch et al., 2012; Malovanyy et al., 2018; Kolesnyk et al., 2016), population growth
(Cheevaporn \& Menasveta, 2003; Jiang, 2009), rapid industrialization (Jiang, 2009) and toxic substances leakage through the soil layers (Parzych et al., 2013; Vambol et al., 2018; Vambol et al., 2019). The current environmental strategies of many countries motivate the scientific 
community to develop reliable (Bobik et al., 2017), economically viable (Jutsz \& Gnida, 2015; Khan et al., 2019) and environmentally friendly technologies that are able to remove pollutants from the environment, including water.

A variety of wastewater treatment technologies are currently available, but with success varying degrees at monitoring and minimizing water pollution (Terentiev et al., 2018; Ölmez \& Kretzschmar, 2009). The main disadvantages of most of these methods are the high maintenance costs, the formation of toxic sludge and the water treatment complicated technology (Bhatnagar et al., 2015). Compared with other processes, the adsorption process is the best alternative for water and wastewater treatment, because it is convenient, easy to operate and simple in design (Bhatnagar et al., 2015; Ali et al., 2012; Gautam et al., 2014). Although, in some cases, is arising need of the adsorbent regeneration or sorbent utilization which has expired (Gautam et al., 2014; Terentiev et al., 2016). And this is often a problem.

In the conditions of the need for rational natural resources use and reducing financial costs, scientists are actively engaged in the useful features study of by-products from various activities such as agriculture and industry. If this waste can be used as an inexpensive adsorbent, it will provide a twofold advantage for environmental protection. Considerable attention is paid to the adsorption properties of food waste and their use to remove various pollutants from water, such as heavy metals (Gambhir et al., 2012; Ziarati et al., 2018). Firstly, the volume of by-products (or waste) can be partially (or much) reduced, and, secondly, a cheap adsorbent, if it is developed, can reduce pollution of wastewater at a reasonable price (Grassi et al., 2012). In addition, the use of organic sorbents and bio-adsorbents makes it possible to more effectively purify natural and waste waters from heavy metal ions (Yadanaparthi et al., 2009; Pourzare et al., 2017).

In a study (Patent CN107129001, A), the authors proposed the use of black tea powder to extract lead ions. This method advantage is the almost complete metal ions removal from the solution at low temperatures and within an acceptable time interval. But the disadvantage of this method is that the adsorbent uses tea powder, which is more expensive than other bio-adsorbents. In addition, due to the small size of the adsorbent particles, there are problems with its subsequent removal. In this case, some of the organic matter (primarily the phenol compounds) are permeating into solution and contaminating of the treated water by organic compounds.

As was shown in our previous studies, one of the promising areas for the heavy metal compounds removal from wastewater is the use of bio-adsorbent from a mixture of black and red tea (Hibiscus sabdariffa L.) leaf waste (Ziarati et al., 2018). The advantages of this bio-adsorbent, unlike others, unlike others (Ziarati et al., 2019):
- Accessibility and cheapness, since it is itself a waste;

- Tea leaves contain almost no organic substances that can contaminate into solution;

- The organic substances presence of tea leaves that very strongly bind heavy metal ions;

- Waste leaves have the shape and size that are most beneficial for adsorption, and the heavy metals removal from the solution;

- Disposal of such an adsorbent can be carried out by known methods that do not require sophisticated equipment.

From the conducted studies it was found that the removal of compounds of heavy metals is almost $100 \%$ and they do not desorbed to the solution even at high temperatures. The amount of adsorbed metals is proportional to the adsorption time, which allows you to determine the minimum time of the adsorption process (Ziarati et al., 2019).

Given the above, the introduction of metal adsorption technology based on the use of a bio-adsorbent from a mixture of black and red tea wastes is of great interest on an industrial scale. Therefore, it is necessary to assess the feasibility of implementing such technology. In this case, important technological parameters are the initial and final concentration of heavy metals, the contact time of the adsorbent with contaminated water, the adsorbent amount (black and red tea) and the ratio of the black and red tea amount in the composition of the bio-adsorbent.

Therefore, the study purpose is to determine of influence regularity of the bio-adsorbent composition and amount on the heavy metals adsorption process. Namely, the adsorption kinetics of cadmium, cobalt and nickel from contaminated water was studied in order to determine the most rational bio-adsorbent dose and the necessary red and black tea dose in bio-adsorbent to achieve MPC if the initial concentrations of heavy metals are known. By rational bio-adsorbent dose and composition we understand an amount at which the metal concentration decreases to the MPC in a minimum time.

\section{Materials and Methods}

The initial concentration of heavy metals, such as cadmium, cobalt and nickel, in untreated wastewater, as well as treated with Hibiscus sabdariffa L. sepals in addition to the residue of black tea, was analyzed. At time intervals: $1,5,10,15,30,40$ minutes (with stirring), the final concentration of heavy metals in the samples was analyzed using atomic absorption spectroscopy. Samples were analyzed using an atomic absorption spectrophotometer model AA-6200 (Shimadzu, Japan) using an air acetylene flame for heavy metals and using at least five standard solutions for each metal. The average of five values is fixed. Data were tested using student t-test to measure the variations 
between the contaminations in wastewater and the dose of bio-adsorbent and contact time parameters before and after treated by bio-adsorbent from a mixture of black and red tea leaf waste. One way analysis of variance (ANOVA) was used for data analysis to measure the variations of metal concentrations using SPSS 22.0 software (SPSS Inc, IBM, Chicago, IL) (Ziarati et al., 2018).

This study is based on a statistical synthesis of the experimental data results and patent research, which were presented in previous publications (Ziarati et al., 2018; Ziarati et al., 2019).

Initially, to study the adsorption process kinetics, the nature of the curve that describes the obtained experimental values was visually analyzed. In this case, the experimental values for each experiment, then for a group of experimental data, then for the entire array of experimental data obtained were analyzed. Various groups of experimental data were formed for analysis:

- The group that combines experimental data obtained for different metals, but for same bio-adsorbent composition;

- The group that combines experimental data obtained for one metal, but for different bio-adsorbent compositions.

To determine the type of adsorption process kinetic regularity, which most adequately and reliably describes the experimental data, the least squares method was used. By a reliable and adequate regularity was understood a regularity in which the determination coefficient is the highest for all experimental data groups.

To determine the values of the coefficients in the exponential regularity, the least squares method was used for the entire data array. First, for each group, the coefficients were selected, then the general dependence was determined and the coefficients for the entire array were selected.

The following nomenclature was used in formulas, equations and calculation:

$\mathrm{C}=\mathrm{C}_{\mathrm{B}}+\mathrm{C}_{\mathrm{R}}$ - total bio-adsorbent dose (bio-adsorbent concentration), g/100 ml;

$\mathrm{C}_{\mathrm{B}}$ - black tea bio-adsorbent dose, $\mathrm{g} / 100 \mathrm{ml}$;

$\mathrm{C}_{\mathrm{R}}$ - red tea bio-adsorbent dose, $\mathrm{g} / 100 \mathrm{ml}$;

$\mathrm{C}_{\mathrm{B}}^{\mathrm{F}}=\left(\mathrm{C}_{\mathrm{B}} / \mathrm{C}\right) 100$ - percentage fraction of the black tea bioadsorbent, $\%$

$\mathrm{C}_{\mathrm{R}}^{\mathrm{F}}=\left(\mathrm{C}_{\mathrm{R}} / \mathrm{C}\right) 100$ - percentage fraction of the red tea bioadsorbent, $\%$

$\mathrm{T}=25 \pm 1-$ solution temperature, ${ }^{\circ} \mathrm{C}$

$\mathrm{pH}$ solution $-\mathrm{pH}=3.5$

$\mathrm{C}_{\mathrm{Me}}$ - current metal concentration $(\mathrm{Cd}, \mathrm{Co}$, or $\mathrm{Ni}$ ) into contaminated water (Eq. 1), mg/l

$\mathrm{C}_{0}$ - initial metal concentration $(\mathrm{Cd}, \mathrm{Co}$, or $\mathrm{Ni})$ into contaminated water (Eq. 1), mg/l

$\mathrm{d}_{1}$ - percentage fraction of fast process (determined on basis of contact time relation) (Eq. 1), \%; $\tau_{1}$ - characteristic time for the first part of contact time relation (Eq. 1), $\min$

$\tau_{2}$ - characteristic time for the first part of contact time relation (Eq. 1), $\min$

$\mathrm{d}_{1}^{\mathrm{Cd}}-$ percentage fraction of fast process for Cd removing (Eq. 2a), \%;

$\mathrm{d}_{1}^{\mathrm{Co}}-$ percentage fraction of fast process for Co removing (Eq. 2b), \%;

$\mathrm{d}_{1}^{\mathrm{Ni}}$ - percentage fraction of fast process for Ni removing (Eq. 2c), \%;

$\tau_{1}^{\mathrm{Cd}}$ - characteristic time for $\mathrm{Cd}$ (first part of contact time relation) (Eq. 3a), min

$\tau_{1}^{\mathrm{Co}}$ - characteristic time for Co (first part of contact time relation) (Eq. 3b), min

$\tau_{1}^{\mathrm{Ni}}$ - characteristic time for $\mathrm{Ni}$ (first part of contact time relation) (Eq. 3c), min

$\tau_{2}^{\mathrm{Cd}}$ - characteristic time for $\mathrm{Cd}$ (second part of contact time relation) (Eq. $4 \mathrm{a})$, $\min$

$\tau_{2}^{\text {Co }}$ - characteristic time for Co (second part of contact time relation) (Eq. $4 \mathrm{~b}$ ), $\min$

$\tau_{2}^{\mathrm{Ni}}$ - characteristic time for Co (second part of contact time relation) (Eq. 4c), min

$\mathrm{R}^{2}$ - determination coefficient

$\Delta$ - average error, $\%$

$\tau$ - contact time of contaminated water with bio-adsorbent, $\min$.

\section{Results}

The results of study (Ziarati et al., 2018) revealed that heavy metals adsorption when using the bio-adsorbent from a mixture of black and red tea wastes ranged from $31 \ldots 50 \%$ after agitation for 40 minutes (equilibration time). To study this problem, the bio-adsorbent with a different ratio of red and black tea was used; the amount of bio-adsorbent was also different. At the same time temperature was $25 \pm 1{ }^{\circ} \mathrm{C}, \mathrm{pH}=3.5$. After the equilibration time a significant further increase of heavy metals adsorption was not observed ( $\mathrm{p} \geq 0.05$ ). Bio-adsorbent dose is one of the most important factors which affect significantly on influence specific uptake of all studied heavy metals: $\mathrm{Ni}, \mathrm{Cd}$ and $\mathrm{Co}$ from waste water effluent. Generally, for low bio-adsorbent dose, there is an enhanced heavy metals sorption especially for Cd and Sorption capacity of different bio-adsorbents have been observed to reduce with increasing bio-adsorbent dose (Fig. 1-3) (Ziarati et al., 2018). 
Bio-adsorbent effect on cadmium removal from contaminated waste water

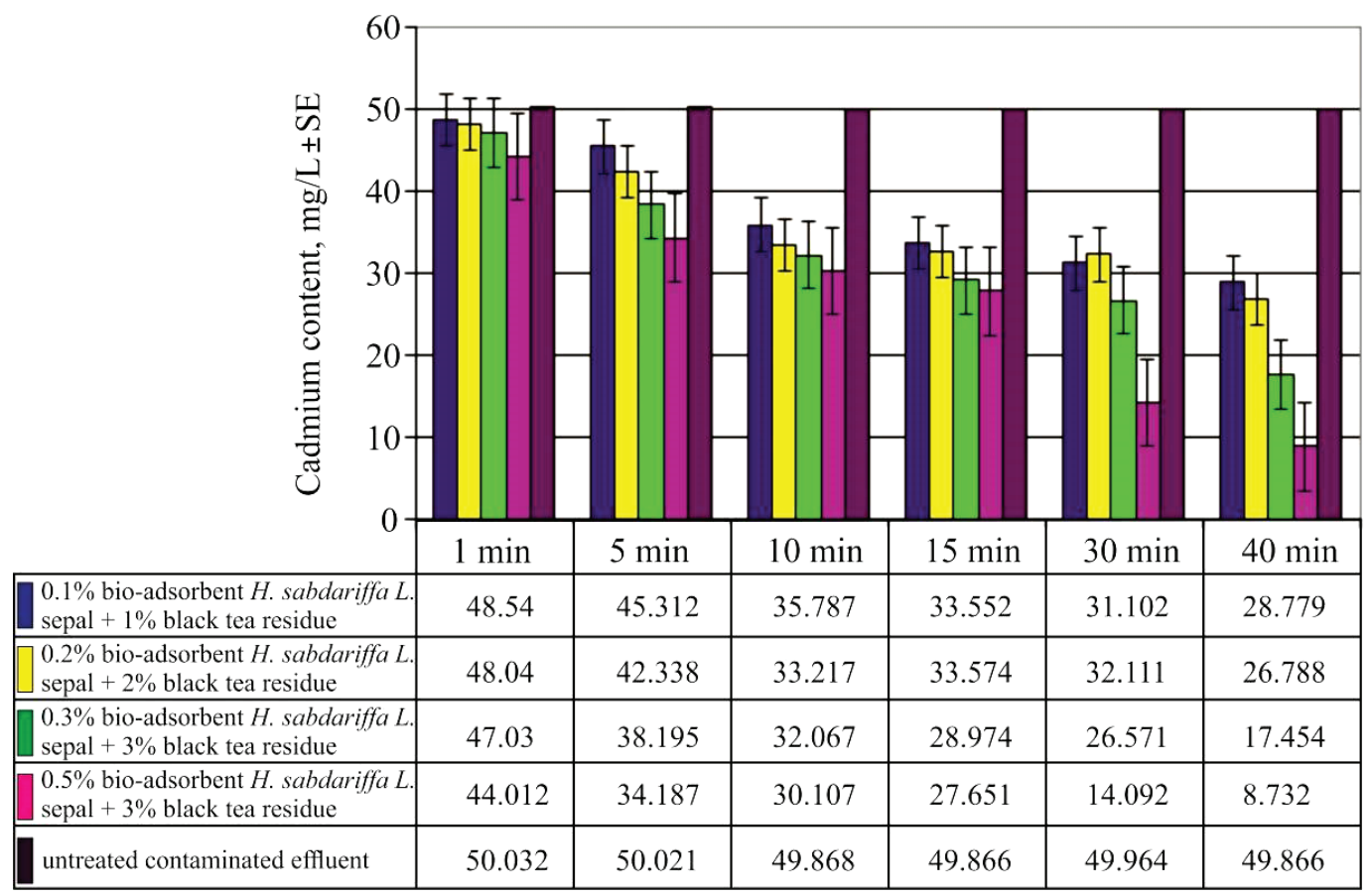

Figure 1. Effect of contact time on the removal of cadmium (initial Cd concentration $=50.032 \mathrm{mg} / \mathrm{l}, \mathrm{T}=25 \pm 1{ }^{\circ} \mathrm{C}, \mathrm{pH}=3.5$ ) (Ziarati et al., 2018)

\section{Bio-adsorbent effect on cobalt removal from contaminated waste water}

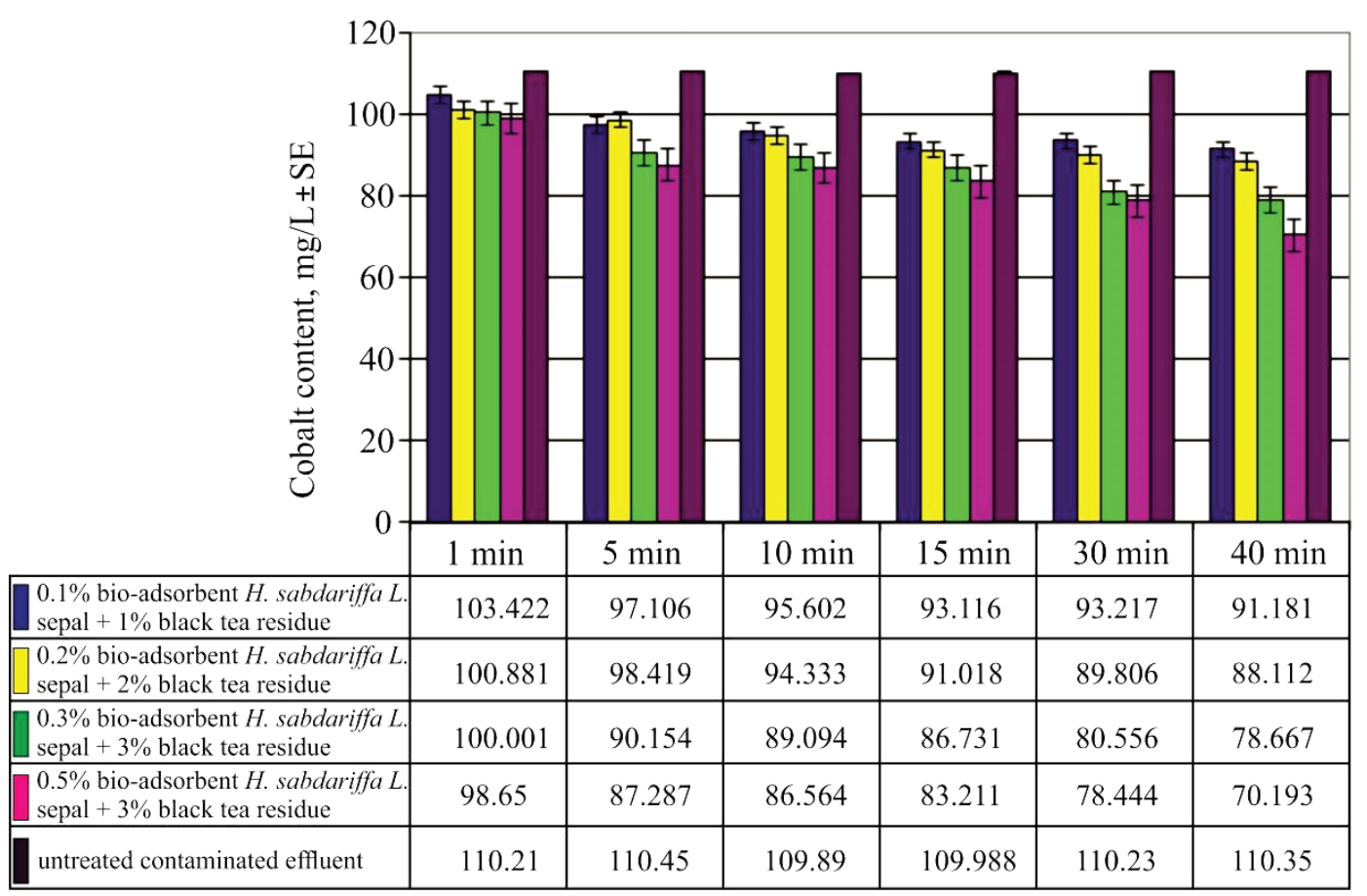

Figure 2. Effect of contact time on the removal of cobalt (initial Co concentration $\left.=110.21 \mathrm{mg} / \mathrm{l}, \mathrm{T}=25 \pm 1{ }^{\circ} \mathrm{C}, \mathrm{pH}=3.5\right)(\mathrm{Ziarati}$ et al., 2018) 


\section{Bio-adsorbent effect on nickel removal from contaminated waste water}

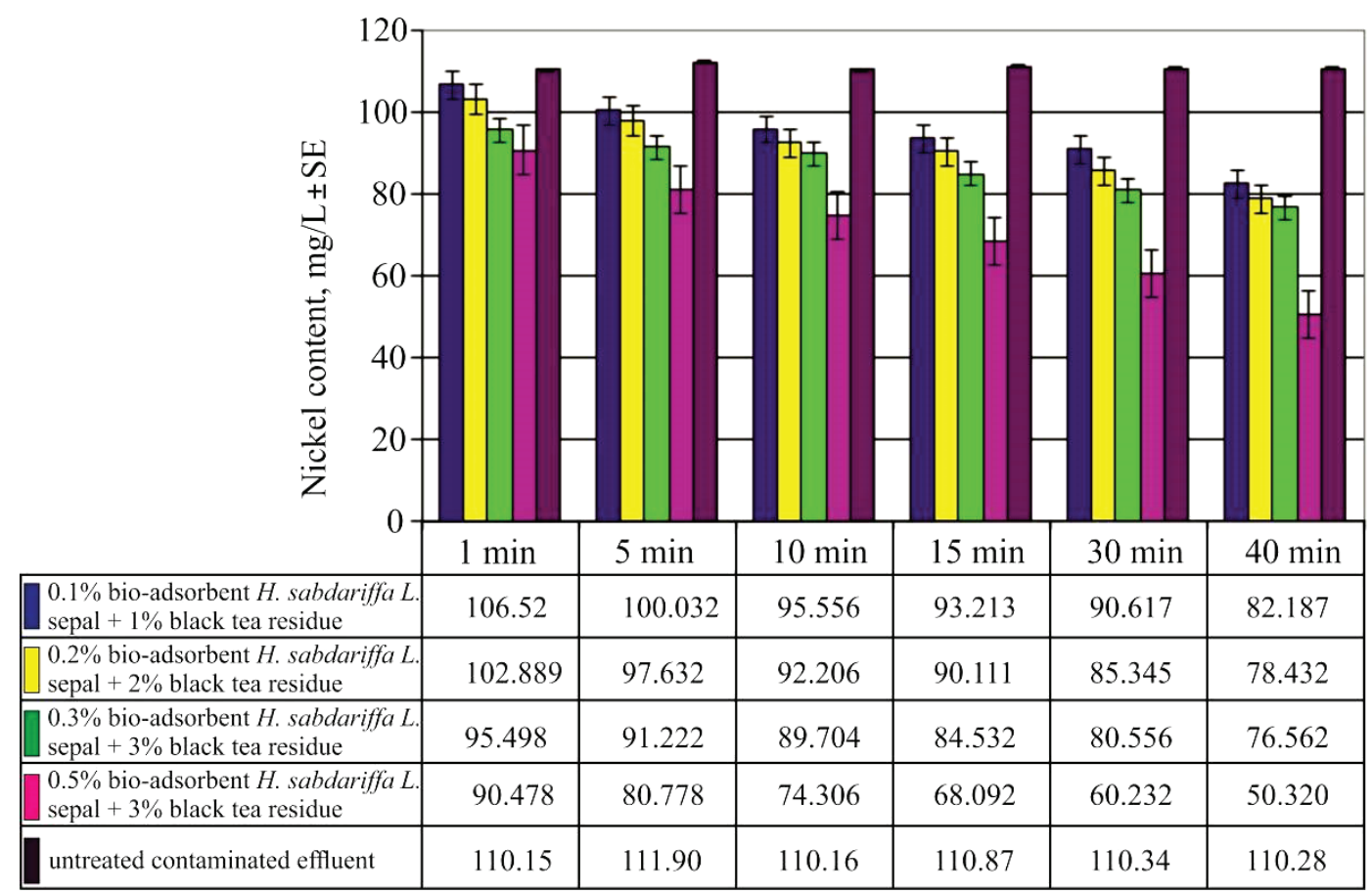

Figure 3. Effect of contact time on the removal of nickel (initial Ni concentration $\left.=110.15 \mathrm{mg} / \mathrm{l}, \mathrm{T}=25 \pm 1{ }^{\circ} \mathrm{C}, \mathrm{pH}=3.5\right)(\mathrm{Ziarati}$ et al., 2018)

Figure 4 and 5 showed examples of kinetic dependences for various bio-adsorbent amounts. Visual assessment of the kinetic dependency shape showed the presence of at least two parts on the chart, but two parts are very pronounced.

The first part of the graph shows a sharp decrease in the concentration of the corresponding metal by $5-10 \%$ of the initial value for 1-5 minutes. Thereafter, there is a slower decrease in concentration in the second part of the graph. Thus, the first part of the graph is characterized by a fast absorption process, which is observed up to 5 minutes (the fast process), and the second part is characterized by a slow absorption process that takes place after 5 minutes from the cleaning start (the slow process).

This form of kinetic dependence is characteristic of all experiments series; therefore, it can be considered as a general dependence for a adsorption process (Fig. 4, 5).

We accentuate that the presence of two different parts indicates that the reaction in the first part is not zero. Since with zero reaction, the kinetic dependence would have the straight line form. Therefore, this process is not due to physical adsorption, but by a chemical process.

For the second part of graph, this conclusion is not unambiguous, since for some series of experiments the concentration dependence on time is close to linear. How- ever, statistical processing of the entire data array showed that the dependence that is responsible for the first order of the kinetic equation is the most adequate. This means that for this part of the graph, adsorption is also determined by a chemical process. This statement is very important because it means that it is impossible to achieve the complete metal ions extraction even with a very long contact time of the bio-adsorbent with contaminated water. On the other hand, the reaction first order means that the adsorption rate depends solely on the metal ions concentration in the solution, that is, there is no change in the chemical adsorbent activity during the adsorption process.

Thus, the exponential regularity best describes all experimental data and the statistical generalization of the results of experimental research of the adsorption process was proposed in this form:

$$
\mathrm{C}_{\mathrm{Me}}=\mathrm{C}_{0} \cdot\left[1-\mathrm{d}_{1} \cdot \mathrm{e}^{-\frac{\tau}{\tau_{1}}}-\left(1-\mathrm{d}_{1}\right) \cdot \mathrm{e}^{-\frac{\tau}{\tau_{21}}}\right]
$$





\section{$\mathrm{C}_{0}, \mathrm{mg} / \mathrm{l}$}



$\mathrm{C}_{0}, \mathrm{mg} / \mathrm{l}$

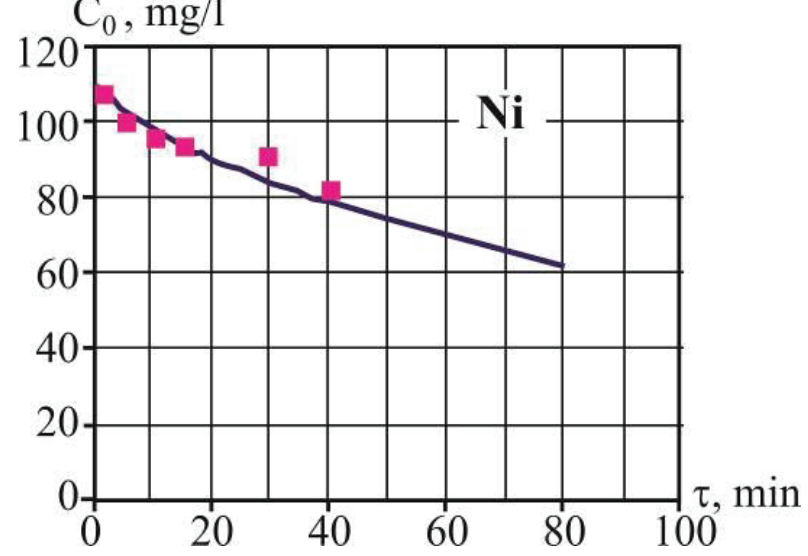

Figure 4. Some kinetic dependencies at at $0.1 \%$ percentage fraction of the red tea bio-adsorbent in accompany of black tea residue, $\mathrm{T}=25 \pm 1{ }^{\circ} \mathrm{C}, \mathrm{pH}=3.5$
$\mathrm{C}_{0}, \mathrm{mg} / \mathrm{l}$



$\mathrm{C}_{0}, \mathrm{mg} / \mathrm{l}$

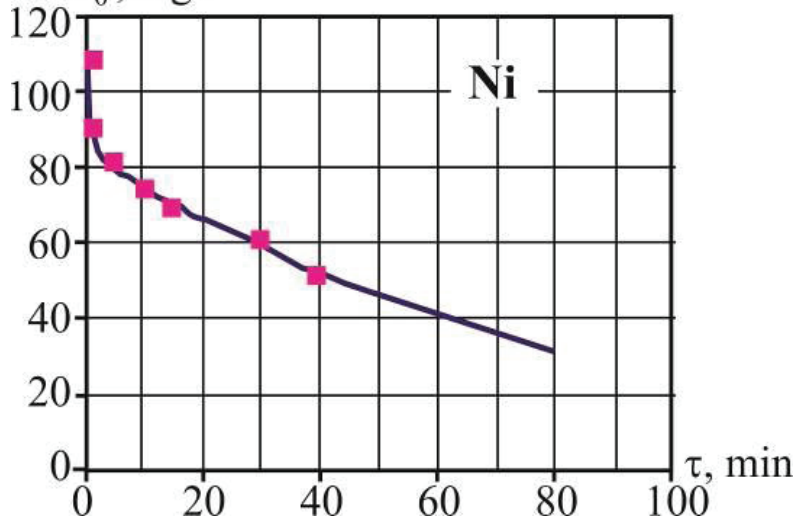

Figure 5. Some kinetic dependencies at $0.5 \%$ percentage fraction of the red tea bio-adsorbent in accompany of black tea residue, $\mathrm{T}=25 \pm 1^{\circ} \mathrm{C}, \mathrm{pH}=3.5$ 
where $\mathrm{C}_{\mathrm{Me}}$ - current metal concentration in solution, $\mathrm{mg} / \mathrm{l}$; $\mathrm{C}_{0}$ - initial metal concentration in solution, $\mathrm{mg} / \mathrm{l} ; \mathrm{d}_{1}-$ proportion of fast process in total adsorption process, $\%$; $\tau_{1}$ - time to concentration reduce of 2.72 times for the first part, $\min ; \tau_{2}$ - time to concentration reduce of 2.72 times for the second part, min.

It allows you to calculate the final metals concentrations values in the solution with their known initial values, the adsorption time and the adsorbent amounts. In this case, the determination coefficient $\mathrm{R}^{2}=0.95$, and the average error $\Delta= \pm 1.6 \%$. Table 1 shows the values of the coefficients for equation (1).

Table 1. The values of the coefficients for equation 1 (all experiments series)

\begin{tabular}{|c|c|c|c|c|c|}
\hline $\mathbf{C}_{\mathbf{R}}$ & $\mathbf{C}_{\mathrm{B}}$ & $\mathbf{d}_{1}$ & $\boldsymbol{\tau}_{1}$ & $\boldsymbol{\tau}_{2}$ & $\Delta$ \\
\hline 0.1 & 1 & 0.395 & 10.831 & 650.04 & 1.80 \\
\hline 0.2 & 2 & 0.335 & 6.558 & 243.94 & 2.10 \\
\hline 0.3 & 3 & 0.254 & 3.863 & 63.12 & 2.09 \\
\hline 0.5 & 3 & 0.145 & 1.019 & 27.88 & 1.71 \\
\hline \multicolumn{7}{|c|}{$\mathrm{Co}$} \\
\hline 0.1 & 1 & 0.123 & 1.647 & 726.12 & 0.85 \\
\hline 0.2 & 2 & 0.114 & 0.830 & 362.93 & 1.72 \\
\hline 0.3 & 3 & 0.162 & 1.274 & 242.72 & 0.64 \\
\hline 0.5 & 3 & 0.173 & 1.158 & 170.50 & 1.55 \\
\hline \multicolumn{7}{|c|}{} & & $\mathrm{Ni}$ & \\
\hline 0.1 & 1 & 0.088 & 2.771 & 225.49 & 1.71 \\
\hline 0.2 & 2 & 0.102 & 1.208 & 181.27 & 1.34 \\
\hline 0.3 & 3 & 0.153 & 0.557 & 200.95 & 1.11 \\
\hline 0.5 & 3 & 0.230 & 0.765 & 79.40 & 1.64 \\
\hline
\end{tabular}

The table shows that the coefficient values for each experiment series are close to each other. This confirms the correctness of the proposed exponential regularity. The presences of regular coefficients changes depending on the bio-adsorbent concentrations and on its composition are also clearly visible from Table 1 . This allows generalizing the coefficients:

$$
\begin{aligned}
& \mathrm{d}_{1}^{\mathrm{Cd}}=0.5072 \cdot \mathrm{e}^{-2.418 \cdot \mathrm{C}_{\mathrm{R}}} ; \\
& \mathrm{d}_{1}^{\mathrm{Co}}=0.109 \cdot \mathrm{e}^{0.966 \cdot \mathrm{C}_{\mathrm{R}}} ; \\
& \mathrm{d}_{1}^{\mathrm{Ni}}=0.06975 \cdot \mathrm{e}^{2.405 \cdot \mathrm{C}_{\mathrm{R}}} .
\end{aligned}
$$

For establish the dependence of the coefficient values on the adsorbent concentration were studied: linear, power, logarithmic and exponential functions. It was found that the smallest error is observed if we use the exponential function. In addition, it was found that the contribution share of the fast adsorption process is associated only with the red tea amount and does not depend on the black tea amount. This most likely indicates that in the absorption process the most important is red tea as a bio-adsorbent component.

The fast process share for cadmium decreases with an increase in the red tea amount, and for cobalt and nickel it increases. However, for all cases, the red tea amount does not exceed $30 \%$ of the adsorbent total capacity. The characteristic time (time during which the metal concentration decreases to $37 \%$ of the initial concentration) for this process also depends on the adsorbent amount, and in different measure for different metals:

$$
\begin{aligned}
& \tau_{1}^{\mathrm{Cd}}=19.417 \cdot \mathrm{e}^{-5.718 \cdot \mathrm{C}_{\mathrm{R}}} ; \\
& \tau_{1}^{\mathrm{Co}}=1.2051 ; \\
& \tau_{1}^{\mathrm{Ni}}=7.656 \cdot \mathrm{e}^{2.223 \cdot \mathrm{C}_{\mathrm{R}}} \cdot \mathrm{e}^{-1.1313 \cdot \mathrm{C}_{\mathrm{B}}}
\end{aligned}
$$

So for cadmium, the characteristic time decreases dramatically from 20 minutes to 1 minute with increasing red tea amounts, for cobalt it remains constant - about 1 minute, and for nickel it increases with increasing red tea amounts and decreases with the black tea addition.

However, the most important is the effect of the adsorbent amounts on the slow process:

$$
\begin{aligned}
& \tau_{2}^{\mathrm{Cd}}=2088.4 \cdot \mathrm{e}^{-3.927 \cdot \mathrm{C}_{\mathrm{R}}} \cdot \mathrm{e}^{-0.78075 \cdot \mathrm{C}_{\mathrm{B}}} ; \\
& \tau_{2}^{\mathrm{Co}}=1740.8 \cdot \mathrm{e}^{-0.9279 \cdot \mathrm{C}_{\mathrm{R}}} \cdot \mathrm{e}^{-0.61074 \cdot \mathrm{C}_{\mathrm{B}}} ; \\
& \tau_{2}^{\mathrm{Ni}}=245.1 \cdot \mathrm{e}^{-4.134 \cdot \mathrm{C}_{\mathrm{R}}} \cdot \mathrm{e}^{0.31655 \cdot \mathrm{C}_{\mathrm{B}}} .
\end{aligned}
$$

So for $\mathrm{Cd}$ and $\mathrm{Co}$, an increase in the black and red tea amount leads to a drastic reduction of the adsorption process time (up to 10 times), while for $\mathrm{Ni}$ the black tea addition slows down the adsorption process.

It should also be noted that the proposed dependences use for the coefficients of equation (1) practically does not reduce the calculations accuracy $(\Delta= \pm 1.68)$.

\section{Discussion}

The feature of the statistical generalization of the results of experimental research, which includes equation (1) and equations systems (2)-(4), is the possibility of heavy metals adsorption process studying if water is contaminated by one metal type or by several types at the same time. 
As can be seen from Figure 6, cadmium adsorption occurs most rapidly. After 2 hours, its concentration in the contaminated water becomes less than the maximum permissible concentration (MPC). To reach acceptable concentrations of $\mathrm{Ni}$ and $\mathrm{Co}$, a longer contact time is required. Using small adsorbent amounts (up to 4\%) this time can be 8-12 hours.

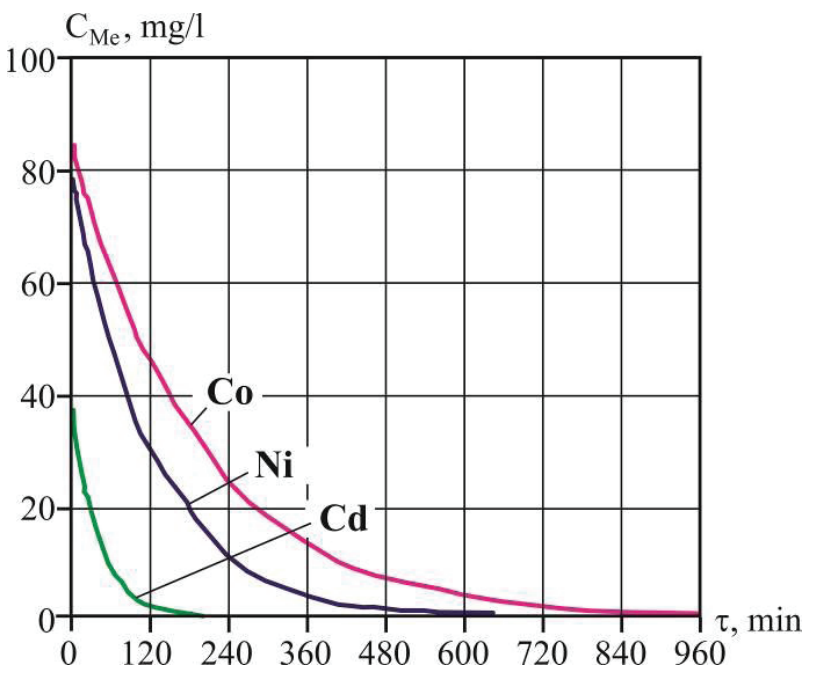

Figure 6. Dependence of heavy metals concentration in the contaminated water on the contact time with the adsorbent (initial concentrations of $\mathrm{Cd}-50 \mathrm{mg} / \mathrm{l}, \mathrm{Co}-100 \mathrm{mg} / \mathrm{l}$ and $\mathrm{Ni}-100 \mathrm{mg} / \mathrm{l}$, adsorbent concentration $-0.4 \%$ red tea and $3 \%$ black tea)

The study also showed a fundamental difference in the influence of the adsorbent composition on the Ni adsorption degree. Unlike $\mathrm{Co}$ and $\mathrm{Cd}$ ions, increasing the black tea concentration reduces the $\mathrm{Ni}$ ion adsorption rate. As a result, we have the red and black tea concentrations, at which complete purification from $\mathrm{Ni}$ is practically impracticable (Fig. 7).

From Figure 8 it can be seen that almost complete $\mathrm{Cd}$ extraction from the contaminated water is possible if the contaminated water contacts 30 minutes with an adsorbent containing 3\% black tea and less than 1\% red tea. A higher red tea concentration (more than $1.5 \%$ ) will reduce the $\mathrm{Ni}$ adsorption, and to ensure the safe concentration of $\mathrm{Co}$, the red tea concentration should be much higher than $2.5 \%$.

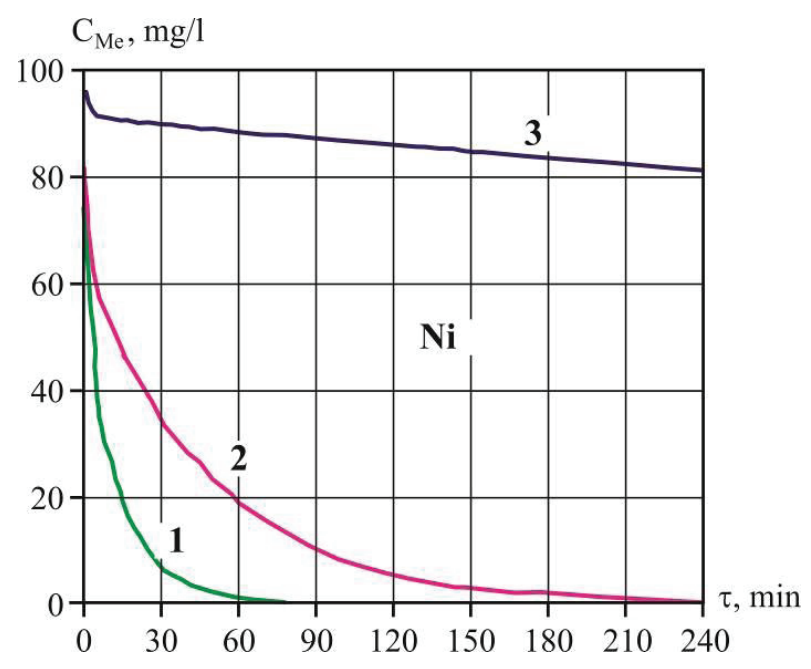

Figure 7. Dependence of Ni concentration in the contaminated water on time: $1-0.9 \%$ red tea and $3 \%$ black tea; $2-$ $0.7 \%$ red tea and $4 \%$ black tea; $3-0.1 \%$ red tea and $8 \%$ black tea

An important technological conclusion follows from this: the technological process of $\mathrm{Cd}$, Co and Ni adsorption can be expedient, if it is carried out in several stages with optimal red and black tea amounts for each of the

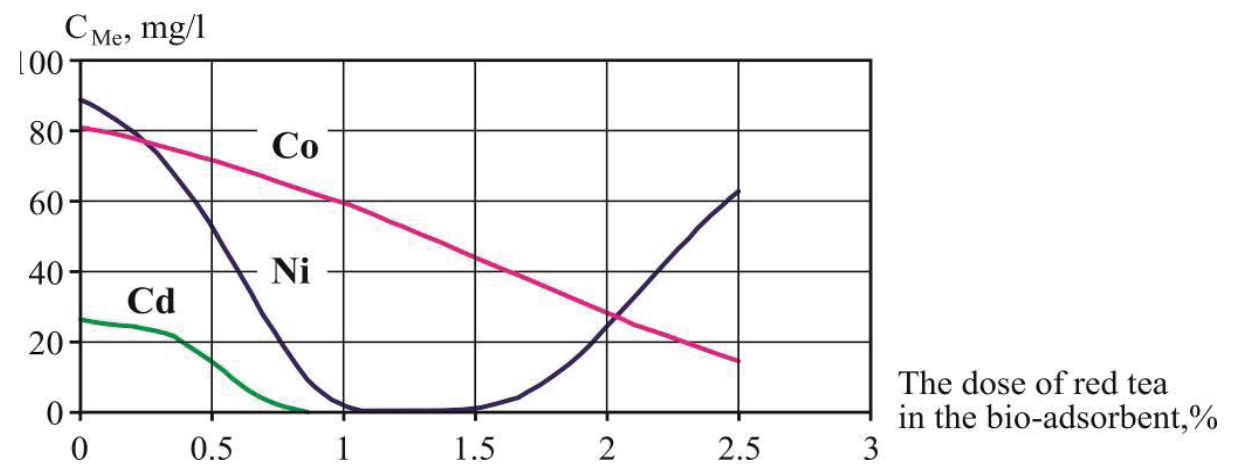

Figure 8. Metals concentration change in contaminated water at various doses of red tea in the bio-adsorbent $(\tau=$ constant), $\mathrm{T}=25 \pm 1{ }^{\circ} \mathrm{C}, \mathrm{pH}=3.5$ 
metals. The important advantage of this approach includes the contaminated bio-adsorbent treatment simplicity after its use.

From a technological viewpoint, water purification is not important until the complete metals removal, but to certain concentration. Therefore, it is required to determine the minimum necessary contact time of the bio-adsorbent with the contaminated water, during which the purification degree of contaminated water may be accepted as acceptable. That is, the heavy metals concentration in contaminated water will not exceed the maximum permissible concentrations values (MPC). A subsequent increase in contact time can be considered economically inexpedient.

According to equation (1), the adsorption degree depends on the contact duration of the bio-adsorbent with contaminated water. If we determine the minimum necessary adsorption time (i.e. contact duration of the bio-adsorbent with contaminated water at which the heavy metals concentration reached values that do not exceed the MPC) for given initial and final concentrations, then it can be easily recalculated for any other values. For the study of the adsorption process kinetic regularity, initial values of the heavy metal concentrations in contaminated water were accepted: Cd - $50 \mathrm{mg} / \mathrm{l}, \mathrm{Co}-100 \mathrm{mg} / \mathrm{l}, \mathrm{Ni}-100 \mathrm{mg} / \mathrm{l}$. As the final values of the heavy metal concentrations in contaminated water, were taken MPC: $\mathrm{Cd}-0.001 \mathrm{mg} / \mathrm{l}$, $\mathrm{Co}-0.1 \mathrm{mg} / \mathrm{l}, \mathrm{Ni}-0.1 \mathrm{mg} / \mathrm{l}$ (Fig. 9).
As can be seen from Figure 9 an increase in the red tea concentration always results in a decrease in the minimum adsorption time. And at a concentration of more than $2.5 \%$, the adsorption time for all metals less than 60 minutes. At the same time, an increase in the concentration does not lead to a monotonic decrease in the minimum adsorption time for $\mathrm{Ni}$, but to dependence with a minimum. Moreover, the value of the minimum depends on the red tea concentration.

Figure 10 shows the dependence of the minimum necessary adsorption time of three metals simultaneously before reaching the MPC on the bio-adsorbent composition. In Figure 10, also seen the minimum necessary adsorption time of three metals when using a bio-adsorbent in which red or black tea is completely absent.

In Figure 10 it is clearly seen that at the red tea absence in the adsorbent (that is, only black tea is used), the adsorption time for all three metals, when they are present simultaneously, is not lower than 4400 min (about 72 hours). If you add $25 \%$ of red tea from the total bio-adsorbent dose, the minimum necessary adsorption time of all three metals to the MPC can be reduced to $45 \mathrm{~min}$. If red tea is used (without black tea), the concentration of which is $3 \%$, then complete extraction of $\mathrm{Cd}, \mathrm{Co}$ and $\mathrm{Ni}$ will be achieved in 30 minutes.

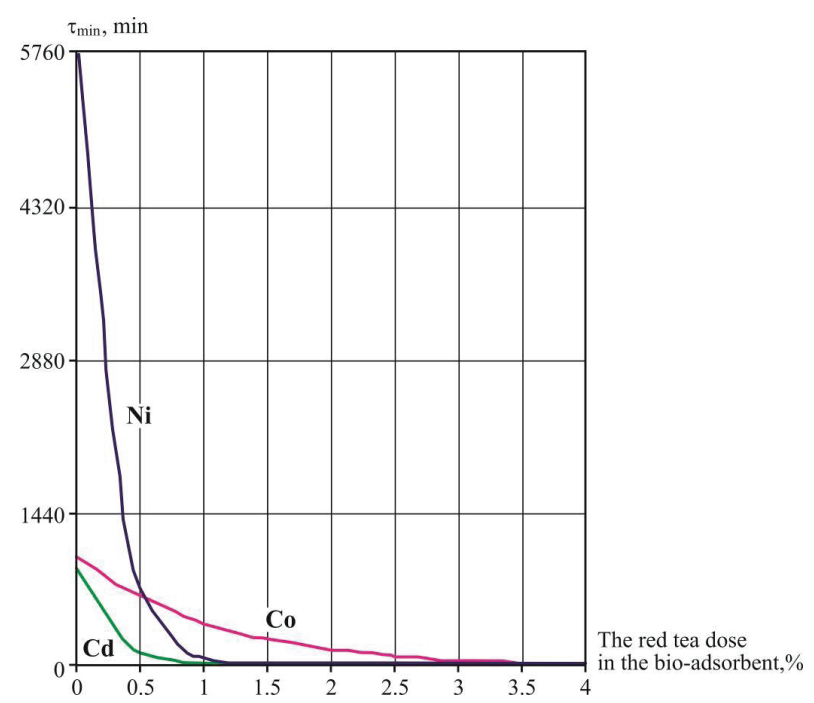

a)



b)

Figure 9. Dependence of minimum necessary adsorption time on the red or black tea dose in the bio-adsorbent: a - the red tea dose is variable, the black tea dose is $4 \%$; $\mathrm{b}$ - the black tea dose is variable, the black tea dose is $0.8 \%, \mathrm{~T}=25 \pm 1{ }^{\circ} \mathrm{C}, \mathrm{pH}=3.5$ 
$\tau_{\min }, \min$

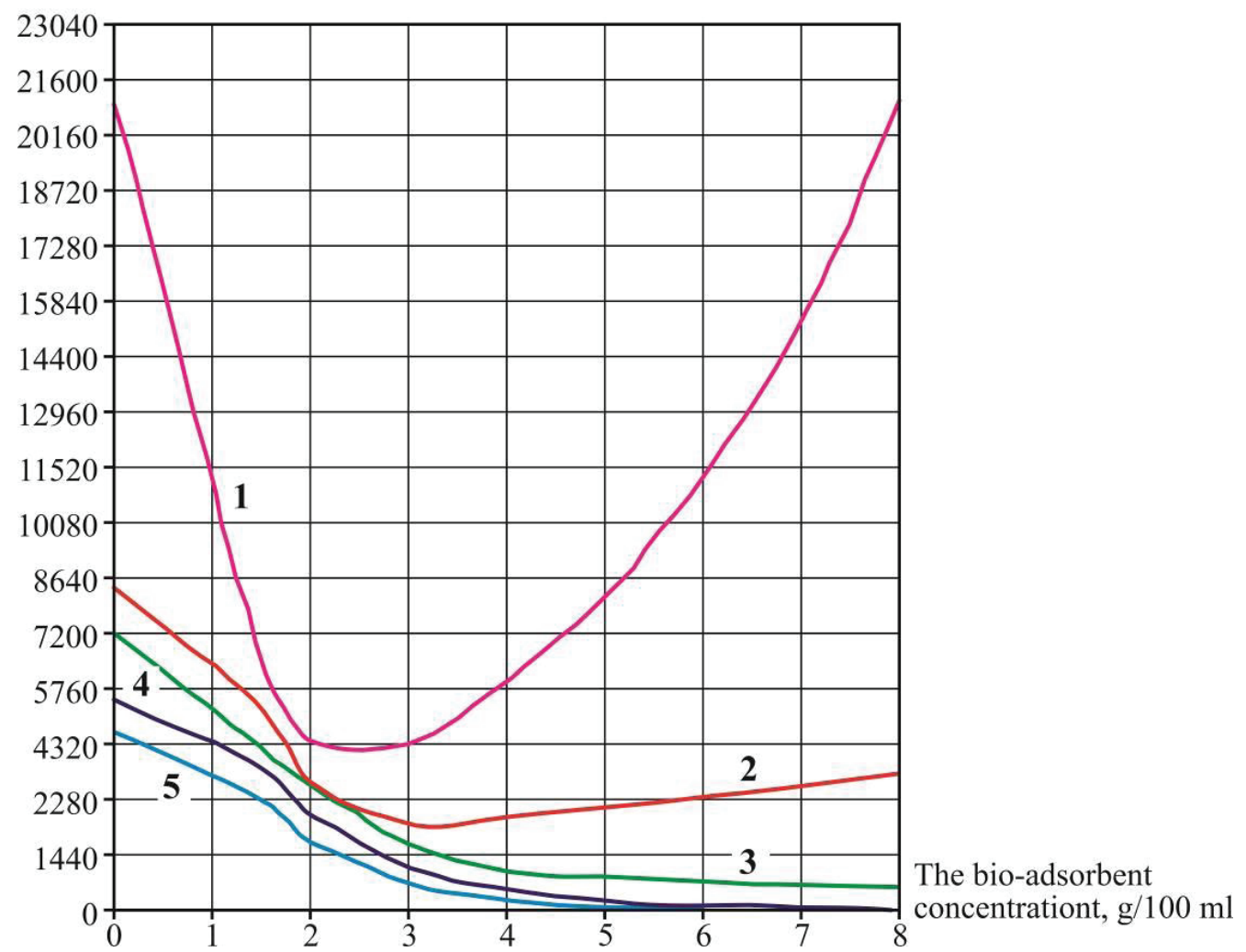

Figure 10. Dependence of the minimum necessary adsorption time of three metals simultaneously before reaching the MPC on the bioadsorbent composition: $1-0 \%$ red tea; $2-5 \%$ red tea; $3-10 \%$ red tea; $4-50 \%$ red tea; $5-100 \%$ red tea, $\mathrm{T}=25 \pm 1{ }^{\circ} \mathrm{C}, \mathrm{pH}=3.5$

\section{Conclusions}

Based on experimental data, the kinetic regularity of the $\mathrm{Cd}, \mathrm{Co}$ and $\mathrm{Ni}$ adsorption from contaminated water were studied using a bio-adsorbent from red and black tea leaves mixture. In this case, the adsorption regularity were studied both for each metal separately and for all three metals simultaneously. Visual assessment of the kinetic dependency shape showed the presence of at least two parts on the chart, but two parts are very pronounced. The first part of the graph shows a sharp decrease in the concentration of the corresponding metal by $5-10 \%$ of the initial value for 1-5 minutes. Thereafter, there is a slower decrease in concentration of metals in contaminated water according to the second part of the graph.

It has been established that red and black tea adsorbs $\mathrm{Cd}$, Co and Ni unequally. The fast process share for $\mathrm{Cd}$ decreases with an increase in the red tea amount, and for $\mathrm{Co}$ and $\mathrm{Ni}$ it increases. However, for all cases, the red tea amount does not exceed $30 \%$ of the total bio-adsorbent dose. It was observed that for $\mathrm{Cd}$ and $\mathrm{Co}$, an increase in the black and red tea amount leads to a drastic reduction of the adsorption process time (up to 10 times), while for $\mathrm{Ni}$ the black tea addition slows down the adsorption process. Therefore, this greatly complicates the implementation of the contaminated water treatment technology from three metals simultaneously on an industrial scale.

Using the adsorption process kinetic regularity, it possible to determine the most rational bio-adsorbent dose and the necessary red and black tea dose in bio-adsorbent to achieve MPC if the initial concentrations of heavy metals are known.

An important technological conclusion was installed: the technological process of $\mathrm{Cd}, \mathrm{Co}$ and $\mathrm{Ni}$ adsorption can be expedient, if it is carried out in several stages with optimal red and black tea amounts for each of the metals. However, adsorption process kinetics study at given initial $\mathrm{Cd}, \mathrm{Co}$ and $\mathrm{Ni}$ concentrations showed, that at the red tea absence in the adsorbent (that is, only black tea is used), the adsorption time for all three metals, when they are pre- 
sent simultaneously, is not lower than 4400 min (about 72 hours). If you add $25 \%$ of red tea from the total bioadsorbent dose, the minimum necessary adsorption time of all three metals can be reduced to $45 \mathrm{~min}$. If red tea is used (without black tea), the concentration of which is $3 \%$, then complete extraction of $\mathrm{Ca}, \mathrm{Co}$ and $\mathrm{Ni}$ will be achieved in 30 minutes. In addition, the proposed statistical generalization of the results of experimental research of the adsorption process can be used to calculate the technological parameters of the process in a wide range of their values.

\section{Acknowledgements}

The authors are thankful to Nutrition and Food Sciences Research Center administration, Tehran Medical Sciences, Islamic Azad University (Tehran, Iran) for their support, as well as the administrations all in which the authors of this article work.

\section{References}

Ali I., Asim M. \& Khan T.A., 2012, Low cost adsorbents for the removal of organic pollutants from wastewater. Journal of Environmental Management 113: 170-183.

Bhatnagar A., Sillanpää M. \& Witek-Krowiak A., 2015, Agricultural waste peels as versatile biomass for water purification - a review. Chemical Engineering Journal 270: 244-271. DOI: 10.1016/j.cej.2015.01.135

Bobik M., Korus I. \& Dudek L., 2017, The effect of magnetite nanoparticles synthesis conditions on their ability to separate heavy metal ions. Archives of Environmental Protection 43(2): 3-9. DOI: 10.1515/aep-2017-0017

Cheevaporn V. \& Menasveta P., 2003, Water pollution and habitat degradation in the Gulf of Thailand. Marine Pollution Bulletin 47(1-6): 43-51. DOI: 10.1016/ S0025-326X(03)00101-2

Gambhir R.S., Kapoor V., Nirola A., Sohi R. \& Bansal V., 2012, Water Pollution: Impact of Pollutants and New Promising Techniques in Purification Process. Journal of Human Ecology 37(2): 103-109. DOI: 10.1080/09709274.2012.11906453

Gautam R.K., Mudhoo A., Lofrano G. \& Chattopadhyaya M.C., 2014, Biomass-derived biosorbents for metal ions sequestration: Adsorbent modification and activation methods and adsorbent regeneration. Journal of Environmental Chemical Engineering 2(1): 239-259. DOI: 10.1016/j.jece.2013.12.019

Grassi M., Kazkioglu G., Belgiorno V. \& Lofrano G., 2012, Removal of Emerging Compounds from water and wastewater by adsorption process, [in:] G. Lofrano (ed.) Emerging Compounds Removal From Wastewater. Springer, Netherlands, pp. 15-37.
Jiang Y., 2009, China's water scarcity. Journal of Environmental Management 90(11): 3185-3196. DOI: 10.1016/j.jenvman.2009.04.016

Jutsz A.M. \& Gnida A., 2015, Mechanisms of stress avoidance and tolerance by plants used in phytoremediation of heavy metals. Archives of Environmental Protection 41(4): 104-114. DOI: 10.1515/aep-2015-0045

Khan N.A., Ahmed S., Vambol S., Vambol V. \& Farooq I.H., 2019, Field hospital wastewater treatment scenario. Ecological Questions 30(3): 57-69. DOI: 10.12775/ EQ.2019.022

Kipigroch K., Janosz-Rajczyk M. \& Wykrota L., 2012, Biosorption of Heavy Metals with the Use of Mixed Algal Population. Archives of Environmental Protection 38(2): 3-10. DOI: 10.2478/v10265-012-0013-9

Kolesnyk V.Ye., Kulikova D.V. \& Pavlychenko A.V., 2016, Substantiation of rational parameters of perforated area of partitions in an improved mine water settling basin. Naukovyi Visnyk Natsionalnoho Hirnychoho Universytetu, 6. (http://nvngu.in.ua/index.php/en/ home/1351-engcat/archive/2016/contents-no-6-2016/ environmental-safety-labour-protection/3778-substantiation-of-rational-parameters-of-perforated-area-ofpartitions-in-an-improved-mine-water-settling-basin). [Accessed 27.06.2019].

Malovanyy M., Krusir G., Holodovska O. \& Masikevych A., 2018, Reagent purification of the processing industry enterprises effluents. Food Science and Technology 12(3): 109-116. DOI: 10.15673/fst.v12i3.1046

Ölmez H. \& Kretzschmar U., 2009, Potential alternative disinfection methods for organic fresh-cut industry for minimizing water consumption and environmental impact. LWT - Food Science and Technology 42(3): 686-693. DOI: 10.1016/j.lwt.2008.08.001

Parzych A., Sobisz Z. \& Trojanowski J., 2013, Prognosis Content of Heavy Metals in Soil and Herbaceous Plants in Selected Pine Forests in the Słowiński National Park, Archives of Environmental Protection 38(4): 35-47. DOI: $10.2478 / \mathrm{v} 10265-012-0038-0$

Patent CN107129001, A, Method of utilizing tea leaves to remove lead ions in wastewater. Inventors: Tang Yuewu, Yang Ying, Tang Yi, Jiang Yong, Chu Jianuan, Zhao Qing, Wang Haibin; 2017-09-05.

Pourzare A., Ziarati P., Mousavi Z. \& Faraji A.R., 2017, Removing Cadmium and Nickel Contents in Basil Cultivated in Pharmaceutical Effluent by chamomile (Matricaria chamomilla L.) Tea Residue. Journal of Scientific Discovery 1(1): jsd17006. DOI: 10.24262/ jsd.1.1.17006

Terentiev O., Tkachuk K., Tverda O. \& Kleshchov A., 2016, Electromagnetic focusing of impurities in water purification. Eastern European Journal of Enterprise Technologies 4/10(82): 10-15. DOI: $10.15587 / 1729-$ 4061.2016.75251 
Terentiev O., Tkachuk K., Tverda O. \& Kleshchov A., 2018, Mathematical model of the reverse water post purification at mining enterprises when using electromagnetic focusing of contaminants. Eastern-European Journal of Enterprise Technologies. 1/10(91): 57-64. DOI: $10.15587 / 1729-4061.2018 .122000$

Vambol S., Vambol V., Kondratenko O., Koloskov V. \& Suchikova Y., 2018, Substantiation of expedience of application of high-temperature utilization of used tires for liquefied methane production. Archives of Materials Science and Engineering 87(2): 77-84. DOI: 10.5604/01.3001.0012.2830

Vambol S., Vambol V., Sundararajan M. \& Ansari I., 2019, The nature and detection of unauthorized waste dump sites using remote sensing. Ecological Questions 30(3): 43-55. DOI: $10.12775 / \mathrm{EQ} .2019 .018$
Yadanaparthi S.K.R., Graybill D. \& Wandruszka R., 2009, Adsorbents for the removal of arsenic, cadmium, and lead from contaminated waters, Journal of Hazardous Materials 171(1-3): 1-15. DOI: 10.1016/j.jhazmat.2009.05.103

Ziarati P., Namvar S. \& Sawicka B., 2018, Heavy metals bio-adsorrption by Hibiscus sabdariffa L. from contaminated weater. Technogenic and ecological safety 4(2): 22-32. DOI: 10.5281/zenodo. 1244568

Ziarati P., Mostafidi M., Arabian S., Vambol S., Vambol V. \& Cozub P., 2019, Water purification method. Patent of Ukraine, Application Number u2019 04687. Kyiv, State Patent Office of Ukraine [in Ukrainian]. 


\title{
Density and distribution of the greater mole rat (Spalax microphthalmus) on the northern border of the area in a region of European Russia
}

\author{
Alexey V. Andreychev ${ }^{1 *}$, Alexandr S. Lapshin ${ }^{2}$ \\ ${ }^{1}$ Department of Zoology, National Research Mordovia State University, Bolshevistskaya Street 68, \\ 430005, Saransk, Russia \\ ${ }^{2}$ Biological Museum, National Research Mordovia State University, Ul'yanova Street 26 A, \\ 430019, Saransk, Russia \\ "corresponding author e-mail: teriomordovia@bk.ru
}

Received: 20 April 2020 / Accepted: 27 October 2020

\begin{abstract}
There are few subterranean mammals in Russia. The aim of the paper is to study the distribution and abundance of greater mole rat in the local population. The characteristic of the local population of the greater mole rat (Spalax microphthalmus) on the northern border of the range with reference to geographical coordinates is given. Our research has been conducted in Republic of Mordovia (European Russia). The field studies were carried out in 2007-2019. The population density in Mordovia is from 2 to 6 individuals/ha. The number of greater mole rat is estimated at 190 individuals. There are 27 to 200 mounds per one hectare of registered area. The distance of the greater mole rat habitat in Mordovia is from 40 to $372 \mathrm{~km}$ from other populations of neighboring regions. It is revealed that animals in the region are confined to pastures and dacha areas. The population density of subterranean rodent populations, such as mole rats, is in equilibrium with the capacity of the environment in which they live. The results on the population density and the number of greater mole rats on the northern border of the species range indicate the oppression of the local population.
\end{abstract}

Key words: subterranean mammals, mound, relative abundance, rodent, Republic of Mordovia.

\section{Introduction}

Herbivores, especially subterranean mammals, can influence per plants, soil structure and chemistry by moving soil (Williams \& Cameron, 1984; Andersen, 1987; Inouye et al., 1987; Benedix, 1993). There are few subterranean mammals in Russia. However, their role is significant in biotopes. They are almost unknown in many regions.

The habitat of the greater mole rat Spalax microphthalmus Guldenstaedt 1770 (Rodentia, Spalacidae) it covers areas with fertile soil and abundant vegetation. It lives in the steppe and forest-steppe of South-Eastern Europe between the Dnieper and the Volga, in the Western Cau- casus (Topachevskii, 1969; Flint et al., 1970; Puzachenko, 1993; Savchenko \& Ronkin, 2006). The Northern boundary runs from Kiev to the southern part of the Chernigov oblast, the Eastern part of the Kursk and Orel oblasts, in the southern outskirts of Tula, Ryazan, Tambov, Penza oblasts, Republic of Mordovia, Nizhny Novgorod oblast, the Chuvash Republic, Ulyanovsk oblast. The extreme Northern point of detection does not rise above the 56th parallel of the northern latitude (flood plain of the Bolshoi Civil, Chuvash Republic). The extreme North-Eastern point of detection is located in the Samara region (Samara oblast). The southern border of the area runs along the coast of the sea of Azov to the East in the South-Western part of the Krasnodar territory and rises in the Stavropol territo- 
ry to the North-East. The border then goes to the Volga North of Volgograd. South-Eastern borders have not been established yet (Puzachenko, 2011).

A great contribution was made to the study of the greater mole rat in Russian theriology by S. L. Ovchinnikova and A. Yu. Puzachenko. More attention to the ecology and biology of the species was given in Kursk, Voronezh, and Belgorod oblasts. For other regions, there is mainly fragmentary information, which, as a rule, is limited to a description of the distribution and status. The mole-rat has a rare species status in Tambov, Ryazan, Samara, and Ulyanovsk oblasts, as well as the republics of Mordovia and Chuvashia. In the context of the foregoing, the research in other regions, in particular, where relict local populations are preserved, is of significance. It is no coincidence that A.Yu. Puzachenko proposes to consider isolated populations as vulnerable or potentially vulnerable. The fact is that, at the end of the Pleistocene, mole-rats inhabited arid steppes, and with the onset of forests in the Holocene, the northern line of its range, as well as many other steppe species, shifted markedly southward and only a few populations remained in the former distribution boundaries. In the Volga region, mole-rat isolates were preserved in the refugia of steppe vegetation in Mordovia, Chuvashia, Nizhny Novgorod, and Samara oblasts.

Many researchers rightly point out that direct observations of the biology and ecology of mole-rat are difficult. This is due to the large length of individual burrows (up to hundreds of meters), seasonal changes in the configuration and direction of burrows on individual sites (Ovchinnikova, 1971; Rado \& Terkel, 1989; Puzachenko, 1993; Vlasov \& Puzachenko, 1993).

The aim of the paper is to study the distribution and abundance of greater mole rat in the local population at the border of the area. These tasks are relevant, since in the literature these aspects are not adequately addressed. In addition, in local animal populations under suboptimal conditions, differences in population density can be observed compared with populations of the main range of the species.

\section{Study area}

The studies were carried out in Ruzaevsky district of the Republic of Mordovia and Saransk urban district (geographical coordinates $54^{\circ} 05^{\prime}-54^{\circ} 09^{\prime} \mathrm{N}$ and $44^{\circ} 59^{\prime}-45^{\circ} 06^{\prime}$ E) (Fig. 1) in 2007-2019 and covered the entire habitat of mole rats in the region. The climate of the region is moderately continental with pronounced seasons throughout the year. The influx of direct solar radiation varies from 5.0 in December to $58.6 \mathrm{~kJ} / \mathrm{cm}^{2}$ in June. Total radiation throughout the year is $363.8 \mathrm{~kJ} / \mathrm{cm}^{2}$; the radiation balance is $92.1 \mathrm{~kJ} / \mathrm{cm}^{2}$. The average annual air temperature var- ies from 3.5 to $4.0{ }^{\circ} \mathrm{C}$. The average temperature of the coldest month (January) is in the range of $-11.5 \ldots-12.3$ ${ }^{\circ} \mathrm{C}$. Temperature drops down to $-47{ }^{\circ} \mathrm{C}$ occur. The average temperature of the warmest month, i.e. July, is in the range of $+18.9 \ldots+19.8{ }^{\circ} \mathrm{C}$. Extreme temperatures in the summer reach $37^{\circ} \mathrm{C}$. The average annual precipitation in the territory is $480 \mathrm{~mm}$. Over the course of observation lasting many years, periods of more and less humidification were noted, ranging between the minimum and maximum values of 120-180 mm. Distribution of precipitation across the territory is not very diverse. The average long-term value of evaporation is calculated to be in the range of 390-460 mm (Yamashkin, 1998).

\section{Material and Methods}

The degree of population of the territory on individual areas was determined by calculating the amount of land emissions on 1-hectare sites (Dukel'skaya, 1932; Gulyaevskaya, 1954; Pavlov et al., 1963; Puzachenko \& Vlasov, 1993). We carried out selective catches from burrows to determine the number of animals in burrow systems with subsequent release (Fig. 1). Catching was carried out in burrows until the noises of the passage of animals were recorded on dictaphones in the burrow. Studies were carried out according to a new methodology that we developed for studying of subterranean mammals (Andreychev, 2018; 2019; Andreychev et al., 2020). They also noted the absence of small animals after catching them in burrows where the ground was not covered with drafts.

Initially, the boundaries of individual habitats of mole rats were revealed, then the directions of the foraging passages were determined. The activity of animals may be surveyed with the use of voice recorders in different parts of colonies. The location of recorders was preliminarily determined on the basis of a map with consideration of the boundaries of animal colonies. A GPS-navigator was used for quick detection of recorders in the field.

When conducting scientific research, we used AIMP 1.75 (2007) and AUDACITY2.1.1 (2015) programs (Andreychev, 2018). During the research period, 200 sound recordings were obtained and processed, with a total length of about 16000 hours. We carried out 496 measurements of distances between mounds mole rats.

\section{Results}

It is revealed that the mole rat lives only in the central part of the region within the Saransk urban district and Ruzaevsky district. Natural and anthropogenic factors in Mordovia have long been limiting the further territorial settlement of this species. The settlement of mole rats to 




Figure 1. Geographical position of the Republic of Mordovia in Russia and distance of the local population of Spalax microphthalmus from other populations of neighboring regions.

Note: $\rightarrow-$ Remoteness of population with the distance indicated $(\mathrm{km})$

- Points of closest populations 
the west and south was limited by the Levzha River and its left tributaries, to the north, by the forest of Saransk, and to the east, by a road and the Insar River. A distinction was made using the OziExplorer program for 13 mole rat habitats (Table 1). The territory of detection of mole rat is currently more than $100 \mathrm{~km}^{2}$. The area was previously 26.8 $\mathrm{km}^{2}$ in 2010. However, the actual inhabited area is 568.3 ha. In 2010 , it was 297.7 ha (11.1\% of the total area). In the study area, the species does not populate fields sown with grain crops, tall grasses, and forest belts. It prefers meadows, pastures, summer cottages, and hayfields. It also settles near ponds and marshy areas.

However, the population of the mole rat is experiencing significant anthropogenic pressure. The mole rat was recorded on pastures, summer cottages, hayfields, and arable lands (Fig. 2). The animals prefer pastures and summer cottages, where from 27 to 200 mounds occur on 1 ha (Table 2).

Table 1. Number and area of the greater mole rat's habitat.

\begin{tabular}{|c|c|c|c|}
\hline Number habitat & Locality & Habitat area, ha & Number, individuals \\
\hline 1 & Levzhenskii & 32.4 & 4 \\
\hline 2 & Dobrovol'nyi & 16.8 & 8 \\
\hline 3 & Klyucharevo (South-East) & 183.8 & 6 \\
\hline 4 & Klyucharevo (North) & 3.4 & 60 \\
\hline 5 & Klyucharevo (West) & 12.5 & 11 \\
\hline 6 & Popovka & 28.2 & 12 \\
\hline 7 & Rybnyi & 110.6 & 18 \\
\hline 8 & Klyucharevskie Vyselki & 77.3 & 3 \\
\hline 10 & Levzha & 51.1 & 2 \\
\hline 11 & Yalga & 10.7 & 2 \\
\hline
\end{tabular}

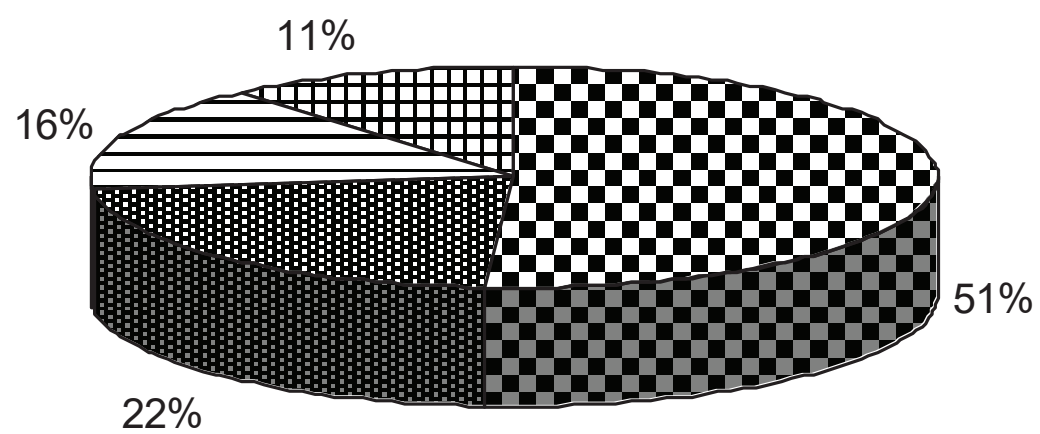

Figure 2. Occurrence of greater mole rat in various anthropogenic habitats in Mordovia.

Note: 1 - pastures; 2 - dacha areas, 3 - haymaking, 4 - arable land 
Table 2. Characteristics of trial registration areas (1 ha), habitats of S. microphthalmus.

\begin{tabular}{|c|c|c|c|c|c|}
\hline Site number & $\begin{array}{c}\text { Geographical } \\
\text { coordinates }\end{array}$ & Locality & $\begin{array}{c}\text { Length of } \\
\text { burrows, m }\end{array}$ & $\begin{array}{c}\text { Burrow } \\
\text { direction } \\
\text { (N,S,W,E) }\end{array}$ & $\begin{array}{c}\text { Density of mounds } \\
\text { per 1 ha }\end{array}$ \\
\hline I & $\begin{array}{c}54.1507 \mathrm{~N}, \\
44.9473 \mathrm{E}\end{array}$ & $\begin{array}{c}\text { Klyucharevskie } \\
\text { Vyselki }\end{array}$ & 160 & $\mathrm{~N}-\mathrm{S}$ & 200 \\
\hline II & $\begin{array}{c}54.1340 \mathrm{~N}, \\
45.0160 \mathrm{E}\end{array}$ & Klucharevo & 134 & $\mathrm{~N}-\mathrm{S}$ & 56 \\
\hline III & $\begin{array}{c}54.1200 \mathrm{~N}, \\
45.0289 \mathrm{E}\end{array}$ & Popovka & 125 & W-E & 105 \\
\hline IV & $\begin{array}{c}54.0998 \mathrm{~N}, \\
45.0964 \mathrm{E}\end{array}$ & Levzhenskii & 110 & W-E & 53 \\
\hline V & $\begin{array}{c}54.0928 \mathrm{~N}, \\
45.0192 \mathrm{E}\end{array}$ & Levzha & 71 & $\mathrm{~N}-\mathrm{S}$ & 25 \\
\hline VI & $\begin{array}{c}54.1329 \mathrm{~N}, \\
45.1316 \mathrm{E}\end{array}$ & Yalga & 281 & $\mathrm{~N}-\mathrm{S}$ & 50 \\
\hline VII & $\begin{array}{c}54.1170 \mathrm{~N}, \\
45.1770 \mathrm{E}\end{array}$ & Kulikovka & 95 & $\mathrm{~N}-\mathrm{S}$ & 30 \\
\hline VIII & $\begin{array}{c}54.0779 \mathrm{~N}, \\
45.1644 \mathrm{E}\end{array}$ & Monastyrskoe & 181 & $\mathrm{~N}-\mathrm{S}$ & 60 \\
\hline
\end{tabular}

The number of the greater mole rat in the total area of habitat in Mordovia was 190 individuals. Moreover, the distribution of land plots is uneven (Table 1). The population density varied from 2 individuals / ha (the villages of Monastyrskoe, the of Kulikovka, the of Novaya Nechayev$\mathrm{ka}$ ) to 6 individuals / ha (the villages of Klyucharevskie Vyselki, of the Klyucharevo, of the Popovka).

The primacy of animals changes to different anthropogenic habitats. Mole rats prefer to settle in the district of summer cottages near the village of Klucharevo. Mole rat inhabits the villages Rybnyi and Levzhenskii in the pastures around ponds. It should be noted that pastures in the Kursk region are considered a suboptimal biotope for the blind (Puzachenko \& Vlasov, 2012). This once again highlights the differences in the animal's biotopes in different regions.

The remoteness of the local mole rat population from other populations of neighboring regions differs. From the populations of the southern regions, namely, Penza and Ulyanovsk oblasts, which are part of the continuous range of the species, the habitat of mole rats from Mordovia is separated by a distance of about 40 and $125 \mathrm{~km}$, respectively. In Penza oblast, the closest biotopes where molerats live are Issinskii and Luninskii districts (Il'in et al., 2006). In Ulyanovsk oblast, the nearest habitat with respect to the population from Mordovia is located in the Bazarnosyzganskii district in the vicinity of the Yasachnyi Syzgan village (Abrakhina et al., 1993). As for identical isolated populations from the Chuvashia and Ryazan and Nizhny Novgorod oblasts, the distances to them from the extreme habitats of the mole rat in Mordovia are 120, 372, and 131 $\mathrm{km}$, respectively. In Chuvashia, only four local populations were noted, the nearest of which is in the Alatyr district (Dimitriev et al., 2010). In Nizhny Novgorod oblast, there are only two isolates in the Mezhp'yan'e (Sergachskii and Krasnooktyabr'skii districts) and on the left bank of the southern branch of the P'yana (the border of the Gaginskii and Shatkovskii districts) (Bakka, 2014). In Ryazan oblast, the habitat is known only on the slopes of the Panika River valley to the southeast of the Chernavskaya oak grove in Miloslavskii district (Didorchuk \& Kotyukov, 2012).

\section{Discussion}

We compared the current range boundaries of the mole rat with data on its distribution in Mordovia in the past (Astradamov et al., 1976; Andreychev et al., 2010; Andreychev, 2020). It should be noted that it significantly expanded the areas of their habitat (Fig. 3). In recent years the mole rat has managed to expand their habitat to the East to the village Kulikovka, West to the village Klyucharevskie Vyselki, South to the village Levzha. No settlement was registered in the North. In Mordovia, the distance between 
the edge detection points of mole rats from north to the south is currently $15 \mathrm{~km}$, and from the west to the east, 10 $\mathrm{km}$. In Mordovia, the distance between the edge detection points of mole rats from the north to the south was $10 \mathrm{~km}$ and from the west to the east, $8.8 \mathrm{~km}$ (Andreychev et al., 2010).
According to the results obtained in Mordovia and in the territories where the population density of S. microphthalmus is higher (Kursk oblast) (Puzachenko \& Vlasov, 1993), animals from our region have low (10-50 mounds per $1 \mathrm{ha}$ ) and medium (100-200 mounds per $1 \mathrm{ha}$ ) intensity of burrowing activity. The smallest occurrence of mounds

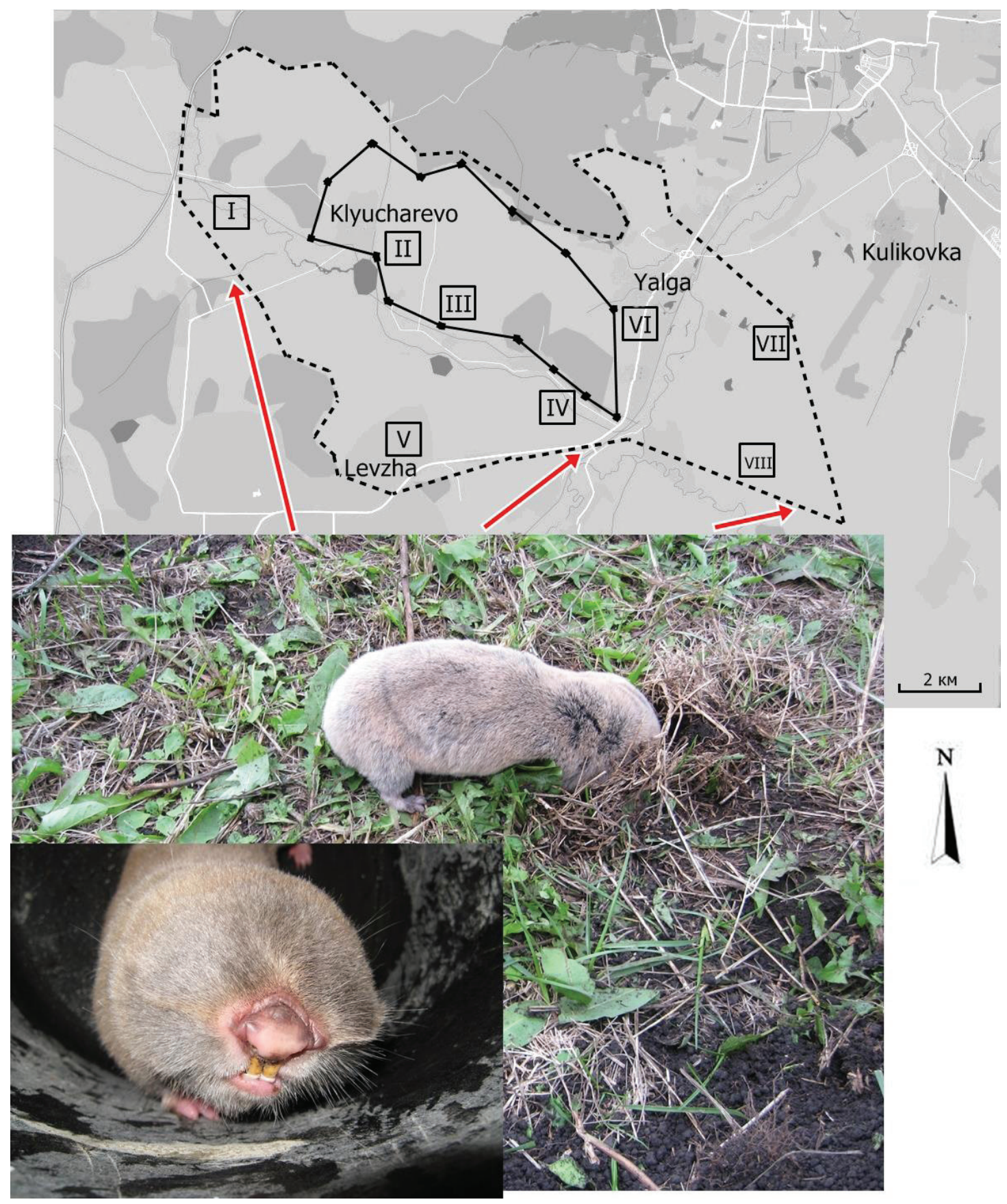

Figure 3. Geographic distribution of greater mole rat in the Republic of Mordovia. Note: A solid black line marks the former border of the greater mole rat habitat (Astradamov et al., 1976), and a dotted black line marks the current border of the greater mole rat habitat (our data, 2019). Black squares indicate the experimental areas for the registration of the greater mole rat (1 ha each). I-VII-site location numbers (see symbols in Table 1) 
mole rats was noted on agricultural arable lands and vegetable gardens; the first type of plots is rejected by the mounds itself, and from vegetable gardens it is actively expelled by humans. Under optimal habitat conditions, the mole rats can form up to 380 mounds per 1 ha, for example, in the steppe of the Lugansk oblast (Gulyaevskaya, 1954).

For comparison, the population density of $S$. microphthalmus was 2.6-4.9 individuals / ha in the Volga foreststeppe reserve in the Penza oblast in 1998-2004 (Il'yin et al., 2006). There, the blind man lives in a single undivided population. The population density for the Voronezh oblast varied from 3 to 20 individuals/ha (Ovchinnikova, 1971). The population density in the virgin steppe of the Lugansk oblast was from 1 to 11 individuals / ha (on average 3.7-3.8) (Gulyaevskaya, 1954).

The results of studying the burrowing activity of the mole rat are poorly displayed in many regions. It is advisable to provide the available data for some regions (Table 3). The data obtained for the territory of Mordovia are consistent with the results of other researchers $(\mathrm{Pu}-$ zachenko \& Vlasov, 1993; Didorchuk \& Kotyukov, 2012). However, the average depth of the upper edge of the stern passage is less in Mordovia $(13.2 \pm 1.49 \mathrm{~cm})$ than in the Kursk and Belgorod oblasts $(22.1 \pm 1.17 \mathrm{~cm})$. The obtained average value of distances between adjacent mounds for Mordovia. It is $3.5 \mathrm{~m}$. The average length of the burrow system is $70.7 \mathrm{~m}(\mathrm{n}=30)$ in Mordovia.

It was found that animals have different indicators of feeding passages in different types of anthropogenic changed habitats. They are slightly different from the same indicators in natural areas (meadows). It is noted that the most common land emissions occur in pastures and dacha plots. Sparseness is shown for haymaking and arable land. The lowest average depth of the upper edge of the stern passage is marked for suburban areas. The greatest weight of the thrown out earth from the passages is registered for haymaking. However, the regularity in the direction of the feeding course is shown from the North-East to the SouthWest for almost all types of anthropogenic habitats (more than $70 \%$ ) of the mole rat in Mordovia.

Cattle graze annually in the number of more than 150 individuals in many areas of the mole rat is habitat. In particular, this is typical for the village of Levzhenskii. We observed numerous failures of feeding passages in pastures. They were formed as a result of trampling the soil by cattle. S. microphthalmus in places of failures of feed passages conduct renewable activity. Gradually, new earth emissions appear. Researchers have found that the appearance of new mounds is a reliable marker of employment of the optimal territory (Zhukov et al., 2011).

Many researchers note that the mole rat can often be found in forest belts (Topachevskii, 1969; Ovchinnikova, 1971). The mole rat avoids these habitats in Mordovia. The nearest mounds were found at a distance of 40 meters. It was on a pasture near the village of Levzhenskii and 60 meters away on a pasture near the village of Klyucharevo.

It is very interesting to compare the features of burrowing activity in different types of mole rat. For example, the Riesen-Blindmaus Spalax giganteus in the Terek-Kumskoe interfluve in the Caucasus. The number of mounds per 1 ha varied from 32 to 456, (on average 181) (Pavlov et al., 1963). The population density of the $S$. giganteus reached 0.5-2 individuals / 1 ha, in the area of the Talovka River (Dagestan) in August 1991 (Puzachenko, 1999). At the same time, the average distance between the mounds was about $5 \mathrm{~m}$.

According to A. Yu. Puzachenko, the same burrow system is inhabited by a sexually Mature female and male greater mole rat. Besides them, fingerlings can be caught. In this regard, the researcher introduced a classification of burrow systems by the size and composition of their inhabitants. He identified three groups of settlements of the greater mole rat. The first group consists of complex burrow systems extending for hundreds of meters, where adult males, females and youngsters live together. The sec-

Table 3. Some characteristics of burrowing activity of S. microphthalmus in different regions

\begin{tabular}{|c|c|c|c|c|}
\hline \multirow{2}{*}{ Region } & \multicolumn{3}{|c|}{ Characteristic } & \multirow{2}{*}{ Source } \\
\cline { 2 - 5 } & $\begin{array}{c}\text { Average distance } \\
\text { between neighboring } \\
\text { mounds, m }\end{array}$ & $\begin{array}{c}\text { Average depth } \\
\text { of burrow from the } \\
\text { soil surface, cm }\end{array}$ & $\begin{array}{c}\text { Average mounds soil } \\
\text { weight, kg }\end{array}$ & $\begin{array}{c}10.6 \pm 1.63 \\
(\mathrm{n}=25)\end{array}$ \\
\hline $\begin{array}{c}\text { Kursk and Belgorod } \\
\text { oblasts }\end{array}$ & $\begin{array}{c}1.9 \pm 0.07 \\
(\mathrm{n}=491)\end{array}$ & $\begin{array}{c}22.1 \pm 1.17 \\
(\mathrm{n}=285)\end{array}$ & - & $\begin{array}{c}\text { Puzachenko, Vlasov, } \\
1993\end{array}$ \\
\hline Ryazan oblast & $\begin{array}{c}1.4 \pm 0.2 \\
(\mathrm{n}=14)\end{array}$ & - & $\begin{array}{c}10.3 \pm 0.44 \\
(\mathrm{n}=280)\end{array}$ & Own data, 2019 \\
\hline Mordovia & $\begin{array}{c}3.5 \pm 0.12 \\
(\mathrm{n}=496)\end{array}$ & $\begin{array}{c}13.2 \pm 1.49 \\
(\mathrm{n}=280)\end{array}$ \\
\hline
\end{tabular}


ond group includes systems that are less extensive (tens or hundreds of meters) and contain only one individual. The third group is formed by the norms of fingerlings that have separated along the periphery of the family's habitat. The length of such burrows is insignificant (tens of meters) (Puzachenko, 1993). According to this classification, the first two groups of settlements are found in Mordovia. They are inhabited by several individuals (settlements near the village of Levzhenskii, the village of Klyucharevo, Popovka, Klyucharevskie Vyselki) and only one individual (Dobrovol'nyi, Novaya Nechayevka, Monastyrskoe, Kulikovka).

The population density of the Palestine mole rat Spalax ehrenbergi in Israel ranged from 91 to 177 individuals per $1 \mathrm{~km}^{2}$ (1 to 1.8 individuals / ha) (Nevo et al., 1982). According to other data, the population density of Spalax golani varied in Israel from 2 to 10 individuals / ha (Lovy et al., 2015). However, the population density of different researchers is within the range of variation for this species from 0.1 to 20 individuals/ha (Savic \& Nevo, 1990). The population density of other subterranean mammals is 4.6-5.2 individuals / ha (Sumbera et al., 2003, 2008). These figures in terms of population density do not differ significantly from $S$. microphthalmus.

The area and length of the burrows of the greater mole rat are similar to other subterranean mammals. The estimated density of mound clusters was $26 \pm 21$ clusters per $\mathrm{km}^{2}$. The average and estimated cluster sizes were four mounds per cluster. Estimated density of $94 \pm 79$ mounds per $\mathrm{km}^{2}$ (Quinn et al., 2010).

The density Pocket gophers (Geomys breviceps) is 1.35 gophers per acre in Texas (Davis et al., 1938). In Texas, densities Geomys bursarius ranged from 1.3, 16.0, and 18.7 individuals / ha in pastureland, riparian sandbar, and hayfield, respectively (Broussard, 1996). Average density estimates per hectare were 20.4 (range 4.0-60.4) in Arkansas (Connior et al., 2010), 7.4-9.9 in Indiana (Mohr \& Mohr, 1936), 12.9 in Wisconsin (Zinnel, 1992), and 5.422.0 in Minnesota (Adams, 1966). Smallwood and Morrison (1999) determined that generally much of the variation can be explained by the size of the study area (Connior, 2011). Average home range sizes for adult female and adult male of the Ozark pocket gopher ( $G$. bursarius ozarkensis) in Arkansas over 2 y of $287.1 \mathrm{~m}^{2}$ and $291.8 \mathrm{~m}^{2}$ (Connior \& Risch, 2010).

The habitat of the zokor is larger than that of the mole rat. The home range of a male zokor exceeds $1500 \mathrm{~m}^{2}$ and is larger than a female range of less than $500 \mathrm{~m}^{2}$ (Zhou $\&$ Dou, 1990). The distribution and population density of plateau zokors are limited by elevation, vegetation, precipitation, and anthropogenic disturbance (Zhang et al., 1999). It was estimated that they occupied a range of approximately $3.8 \times 106$ ha at an average density of 15 individuals / ha, but ranging from five to more than 70 per hectare in
Qinghai province in the 1980s (Wang \& Fan, 1987; Zhang et al., 1999; Zhang et al., 2003; Zhang, 2007). This population density of the zokor is several times higher than that of the greater mole rat.

\section{Conclusions}

Thus, it can be concluded that the population density of subterranean rodent populations, such as mole rats, is in equilibrium with the capacity of the environment in which they live. The population density of the greater mole rat in Mordovia varied from 2 to 6 individuals / ha. The number in the total area of habitat was 190 individuals. The results on the population density and the number of greater mole rats on the northern border of the species range indicate the oppression of the local population. In most subterranean mammals species a population's growth rate is a decreasing function of density. This explains the relative stability of animal populations, which never continue to increase at rates their fertility would allow, and rarely decrease to extinction (Tanner, 1966).

\section{Acknowledgement}

We are grateful to G. F. Salmov and R. M. Kulahmetov for support in carrying out of field studies. We are grateful to two anonymous reviewers for their constructive comments and feedback on an earlier version of this paper.

\section{References}

Abrakhina I.B., Osipova V.B. \& Tsarev G.N., 1993, Pozvonochnye zhivotnye Ul'yanovskoi oblasti (Vertebrates of the Ulyanovsk Oblast), Ul'yanovsk: 50-63. [in Russian].

Adams G.D., 1966, Populations and spatial distribution of pocket gophers (Geomys b. bursarius). Ph.D. dissertation, University of Minnesota, Minneapolis.

Andersen D.C., 1987, Geomys bursarius burrowing patterns: influence of season and food patch structure. Ecology 68: 1306-1318.

Andreychev A.V., 2018, A new methodology for studying the activity of underground mammals. Biology Bulletin 45: 937-943. http://dx.doi.org/10.1134/ S1062359018080022

Andreychev A.V., 2019, Daily and seasonal feeding activity of the greater mole-rat (Spalax microphtalmus, Rodentia, Spalacidae). Biology Bulletin 46: 1172-1181. http://dx.doi.org/10.1134/S1062359019090012

Andreychev A., 2020, Proportion faunal assemblage of rodents in geoecological districts of Mordovia, Rus- 
sia. Biodiversitas 21(9): 3961-3968. http://dx.doi. org/10.13057/biodiv/d210906

Andreychev A.V., Lapshin A. S. \& Kuznetsov V. A., 2010, On the spread of the greater mole rat in the Republic of Mordovia. XXXVIII Ogaryov Readings. Publisher of the Mordovia State University: Saransk: 13-14. [in Russian].

Andreychev A., Kuznetsov V., Lapshin A. \& Alpeev M., 2020, Activity of the Russian desman Desmana moschata (Talpidae, Insectivora) in its burrow. Therya 11(2): 161-167. http://dx.doi.org/10.12933/therya-20-801

Astradamov V.I., Vechkanov V.S., Machinskii A.P. \& Zadal'skii S.V., 1976, The blind mole rat in Mordovia and its helminthofauna, in Ekologicheskie issledovaniya nazemnykh I vodnykh zhivotnykh v Mordovii (Ecological Studies of Terrestrial and Aquatic Animals in Mordovia), Publisher of the Mordovia State University: Saransk, pp. 61-69. [in Russian].

Bakka S.V., 2014, Blind mole rat, in Krasnaya kniga Nizhegorodskoi oblasti (The Red Data Book of the Nizhny Novgorod Oblast), vol. 1: Zhivotnye (Animals), 2nd ed. Nizhny Novgorod, pp. 65-67. [in Russian].

Benedix J.H., 1993, Area-restricted search by the plains pocket gopher (Geomys bursarius) in tallgrass prairie habitat. Behavioral Ecology 4(4): 318-324. http:// dx.doi.org/10.1093/beheco/4.4.318

Broussard D.R., 1996, The relationships between population demographics of Geomys bursarius and the variability of its food base. M.S. thesis, Baylor University, Waco, Texas.

Connior M.B., 2011, Geomys bursarius (Rodentia: Geomyidae). Mammalian Species 43: 104-117. http:// dx.doi.org/10.1644/879.1

Connior M.B. \& Risch T.S., 2010, Home Range and Survival of the Ozark Pocket Gopher (Geomys bursarius ozarkensis) in Arkansas. The American Midland Naturalist 164(1): 80-90. http://dx.doi.org/10.1674/00030031-164.1.80

Connior M.B., Kershen A.A., Medlin R.E., Elrod D.E., Sasse D.B. \& Risch T.S., 2010, Distribution and habitat affinities of an endemic pocket gopher. American Midland Naturalist 164: 217-229.

Davis W.B., Ramsey R.R. \& Arendale J.M., 1938, Distribution of Pocket Gophers (Geomys Breviceps) in Relation to Soils. Journal of Mammalogy 19(4): 412-418. http://dx.doi.org/10.2307/1374224

Didorchuk M.V. \& Kotyukov Yu.V., 2012, Data on the current distribution of the blind mole rat in the Ryazan oblast. Actual Problems of Modern Mammalogy, Novosibirsk, $12 \mathrm{pp}$. [in Russian].

Dimitriev A.V., Konovalenko A.V., Rakhmatullin M.M. \& Sinichkin E.A., 2010, Blind mole rat. The Red Data Book of the Chuvash Republic, Cheboksary, 278 pp. [in Russian].
Dukel'skaya N.M., 1932, Biology of the greater mole rat and testing different methods to combat. Tr. Zashch. Rast. 4(2): 23-46. [in Russian].

Flint V.E., Chugunov Yu.D. \& Smirin V.M., 1970, Mammals of the USSR. Mysl', Moscow. [in Russian].

Gulyaevskaya N.S., 1954, Digging activity (Spalax micropthalmus Guld) and its landscape and agricultural significance, Extended Abstract. Cand. Sci. (Biol.) Dissertation, Moscow. [in Russian].

Il'in V.Yu., Bystrakova N.V., Dobrolyubov A.N., Ermakov O.A., Zolina N.F., et al., 2006, Synapsis of mammalian fauna of the Penza oblast. Izv. Penz. Gos. Pedagog. Univ. im. V.G. Belinskogo 1(5): 73-89. [in Russian].

Inouye R.S., Huntly N.J., Tilman D. \& Tester J.R., 1987, Pocket gophers (Geomys bursarius), vegetation, and soil nitrogen along a successional sere in east central Minnesota. Oecologia 72: 178-184. http://dx.doi. org/10.1007/BF00379264

Lovy M., Skliba J., Hrouzkova E., Dvorakova V., Nevo E. \& Sumbera R., 2015, Habitat and burrow system characteristics of the blind mole rat Spalax galili in an area of supposed sympatric speciation. PLoS ONE 10(7): e0133157. http://dx.doi.org/10.1371/journal. pone. 0133157

Mohr C.O. \& Mohr W.P., 1936, Abundance and digging rate of pocket gophers, Geomys bursarius. Ecology 17: 325-327.

Nevo E., Heth G. \& Beiles A., 1982, Population structure and evolution in subterranean mole rats. Evolution 36(6): 1283-1289.

Ovchinnikova S.L., 1971, Distribution of the greater mole rat (Spalax microphthalmus Guld.) in the southeastern part of the Black Earth Center. Tr. Voronezh. Univ. 93: 80-83. [in Russian].

Pavlov A.N., Vasilenko V.S., Kolesnikov I.M., Myalkovskaya S.A. \& Potapova E.A., 1963, On the modern distribution of the Riesen-Blindmaus Spalax giganteus in the north-eastern Ciscaucasia. Zoologicheskii Zhurnal 42(5): 777-780. [in Russian].

Puzachenko A.Yu., 1993, Space pattern of the microgroupings in subterranean mole rat Spalax microphthalmus (Rodentia, Spalacidae) populations. Mammalia 57(4): 619-648.

Puzachenko A.Yu., 1999, Methodology for assessing the environmental status of representatives of the family of mole rats (Sapacidae, Rodentia) of mole rats. Rare species of mammals in Russia and neighboring countries. Moscow: 317-329. [in Russian].

Puzachenko A.Yu., 2011, Greater mole-rat, Biodiversity Conservation Center, http://www.biodiversity.ru/programs/rodent/species/spalax_microphthalmus.html [Accessed January 27, 2016].

Puzachenko A.Yu. \& Vlasov A.A., 1993, Diggin activity of the mole rat Spalax microphthalmus (Rodentia, 
Spalacidae). Zoologicheskii Zhurnal 72(11): 91-103. [in Russian].

Puzachenko A.Yu. \& Vlasov A.A., 2012, The dynamics of the population density of the greater mole rat (Spalax microphthalmus, Rodentia) in the "Streletskaya Steppe". Regimes of Specially Protected Steppe Areas: Proc. Int. Sci.-Pract. Conf. Dedicated to the 130th Anniversary of Birthday of Professor V.V. Alekhin, Kursk: 161-168. [in Russian].

Quinn V.S., Tsai C.C. \& Zollner P.A., 2010, Distribution of the Plains Pocket Gopher (Geomys bursarius) in the grassland physiographic regions of Indiana. Proceedings of the Indiana Academy of Science 119(1): 87-94.

Rado R. \& Terkel J., 1989, A radio-tracking system for subterranean rodents. Journal Wildlife Manag. 53(4): 946-949.

Savic I.R. \& Nevo E., 1990, The Spalacidae: evolutionary history, speciation and population biology, [in:] E. Nevo, O.A. Reig (eds), Evolution of subterranean mammals at the organismal and molecular levels. Alan R. Liss, Inc., V, New York, 335: 129-153.

Savchenko G.A. \& Ronkin V.I., 2006, The role of the original and introduced heterogeneity in the formation of the complexity of steppe ecosystems of northeastern Ukraine, Vestn. Khar'kov. Nats. Univ. im. V.N. Karazina 729: 185-192.

Smallwood K.S. \& Morrison M.L., 1999, Spatial scaling of pocket gopher (Geomyidae) density. Southwestern Naturalist 44: 73-82.

Sumbera R., Burda H., Chitaukali W.N. \& Kubova J., 2003, Silvery mole-rats (Heliophobius argenteocinereus, Bathyergidae) change their burrow architecture seasonally. Naturwissenschaften 90: 370-373.

Sumbera R., Skliba J., Elichova M., Chitaukali W.N. \& Burda H., 2008, Natural history and burrow system architecture of the silvery mole-rat from Brachystegia woodland. Journal of Zoology 274: 77-84.

Tanner J.T., 1966, Effects of Population Density on Growth Rates of Animal Populations. Ecology 47(5): 733-745. http://dx.doi.org/10.2307/1934260

Topachevskii V.A., 1969, Spalacidae, Fauna of the USSR. Mammals, Leningrad: Nauka: 3(3). [in Russian].
Vlasov A.A. \& Puzachenko A.Yu., 1993, Distribution of the greater mole rat (Spalax microphthalmus Guldenstaedt 1770, Rodentia, Spalacidae) burrow systems in the protection meadow steppe. Russian Journal of Ecology 4: 88-90. [in Russian].

Wang Q. \& Fan N., 1987, Studies on the digging activities and exploration about the method of number estimation of plateau zokor. Acta Theriologica Sinica 7: 283- 290.

Williams L.R. \& Cameron G.N., 1984, Demography of dispersal in attwater's pocket gopher (Geomys attwateri). Journal of Mammalogy 65(1): 67-75. http:// dx.doi.org/10.2307/1381201

Yamashkin A.A., 1998, Physico-geographical conditions and landscapes of Mordovia. (Yamashkin, A.A., ed.). Publisher of Mordovia State University. Saransk, Russia, $156 \mathrm{pp}$.

Zhang Y., 2007, The Biology and Ecology of Plateau Zokors (Eospalax fontanierii), [in:] S. Begall, H. Burda, C.E. Schleich (eds), Subterranean Rodents. Springer, Berlin: Heidelberg. http://dx.doi.org/10.1007/978-3540-69276-8_17

Zhang Y., Fan N. \& Wang Q., 1999, The effects of some environmental factors on population abundance of plateau zokor. Acta Biologica Plateau Sinica 14: 101-109.

Zhang Y., Zhang Z. \& Liu J., 2003, Burrowing rodents as ecosystem engineers: the ecology and management of plateau zokors Myospalax fontanierii in alpine meadow ecosystems on the Tibetan Plateau. Mammal Review 33(3-4): 284-294. http://dx.doi.org/10.1046/j.13652907.2003.00020.x

Zhou W. \& Dou F., 1990, Studies on activity and home range of plateau zokor. Acta Theriologica Sinica 10: 31-39.

Zhukov A.V., Kunakh O.N. \& Konovalova T.M., 2011, The landscape aspect of the ecological niche of mole rats (Spalax micropthalmus Guldenstaedt 1770). Biological textbook of the Melitopol Sovereign Pedagogical University im. Bogdan Khmelnitsky 3: 13-27.

Zinnel K.C., 1992, Behavior of free-ranging pocket gophers. Ph.D. dissertation, University of Minnesota, Minneapolis. 


\title{
Functional diversity of earthworm communities in forests in the south of the Russian Far East
}

\author{
Anna Geraskina ${ }^{1}$, Alexander Kuprin ${ }^{2}$ \\ ${ }^{1}$ Center for Forest Ecology and Productivity Russian Academy of Sciences, Moscow, Russian Federation \\ ${ }^{2}$ Federal Scientific Center of the East Asia Terrestrial Biodiversity, Far Eastern Branch Russian Academy \\ of Sciences, Vladivostok, Russian Federation \\ corresponding author e-mail: angersgma@gmail.com
}

Received: 25 June 2020 / Accepted: 4 December 2020

\begin{abstract}
Key species of soil macrofauna - large soil saprophages, i.e. earthworms - have been studied in unique in terms of floristic and faunal diversity, as well as the most preserved forests of the southern Russian Far East. The results of studying taxonomic and functional diversity of earthworms, their biomass and abundance and patterns of temporal spatial distribution in summer seasons, are presented. The complete set of the main functional groups of earthworms (epigeic, epi-endogeic, endogeic and anecic) was found only in the best-preserved valley forests, with no traces of logging and fires over the last century. The earthworm community is not complete (one or two functional groups are missing) in one of valley forest that was partially cut down and affected by fires in recent decades and in hillside forests. Horizontal spatial distribution was analysed for the epi-endogeic and endogeic groups of earthworms, dominating in terms of biomass and occurrence. It was found that, in the summer season, the group of epi-endogeic species showed the "covering" type of distribution (regular distribution without aggregation), whereas the group of endogeic species showed the "spotty" type of distribution (aggregated distribution).
\end{abstract}

Keywords: biodiversity, biomass, fractal design, functional groups, invertebrates, litter, polydominant forest, Red List species, saprophages, soil, spatial distribution.

\section{Introduction}

Modern studies of the structure and diversity of soil invertebrates make sense in the most preserved forest ecosystems that have not been exposed to anthropogenic impacts for a long time. Technogenic impacts (Dunger et al., 2001; Dunger \& Voigtländer, 2005; Hüttl \& Weber, 2001; Prescott et al., 2019; Mordkovich \& Lyubechanskii, 2019) and fires (Wikars \& Schimmel, 2001; Buckingham et al., 2019) are the most destructive for soil; they can result in a serious decrease in the diversity and functions of soil biota, the recovery of which proceeds extremely slowly and depends on the extent and duration of the disturbance. The polydominant forests of the southern Far East are of great interest for ecological and taxonomic studies of all biota components, as they are characterised by the floristic and faunal diversity and endemism that are unusually high for Russia. The territory of Southern Primorye alone is home to more than 2.500 species of vascular plants, with at least 250 species of trees, shrubs and woody vines. There are 127 endemic plant species in Primorsky Krai and 156 in Khabarovsk Krai (Kozhevnikov \& Kozhevnikova, 2014). The southern Far East is an endemic habitat of the largest beetle in Russia, Callipogon relictus Semenov, 1899 (Cerambycidae) (Kuprin \& Bezborodov, 2012; Kuprin \& Kharchenko, 2013; etc.), which is included in the Red List of the Russian Federation as a threatened species (category II). The most diverse and unique fauna amongst soil invertebrates is that of the oribatid mites (Ryabinin, 2011), collembolans (Kuznetsova et al., 2019) and mil- 
lipedes (Mikhaleva, 2017). There are four earthworm families: Lumbricidae, Criodrilidae, Megascolecidae and Moniligastridae, while only one family, the Lumbricidae, is mainly represented throughout most of the territory of Russia. At the same time, Drawida ghilarovi Gates, 1969, a representative of the tropical family Moniligastridae, is endemic to the southern Far East and is typical for a number of forest, meadow and meadow-marsh communities (Ganin \& Atopkin, 2018); however, the species is declining in number and is on the Red List of the Russian Federation (category II).

Biodiversity and uniqueness of the flora and fauna of the southern Far East and the preservation of tertiary relics are a result of the complex geological history of this region, which was defined by the collision of the Indian and Asian tectonic plates 70 million years ago and which allowed tropical species to settle in this territory (Easton, 1981). Moreover, the monsoon climate and heterogeneous terrain, i.e. mid-mountain, low-mountain and hillocky areas with complex differentiation of plant and soil groupings (Starozhilov, 2010), create a variety of conditions that essentially distinguish this region from others within the territory of Russia.

At the same time, the forests of Southern Primorye have also been exposed to human economic activity (Naumov, 2012); therefore, when assessing the ecosystem functions of forests, it is necessary to identify the most preserved forest areas, which are characterised by a stable structural and functional diversity of all biota components. One of important criteria of forest ecosystem sustainability is the state of key species populations (Smirnova \& Toropova, 2016), amongst which earthworms are of great importance in the soil fauna of mixed and broad-leaved forests.

The objective of this work is to assess the earthworm community as an indicator group of the state of forest ecosystems. The aims of this study were: 1) to assess the diversity, abundance, biomass and composition of the functional groups of earthworms and 2) to assess the patterns of temporal spatial distribution of the dominant groups of earthworms: epi-endogeic and endogeic.

\section{Study area}

The research was carried out in three nature reserves of Southern Primorye (Fig. 1, Fig. 2). Within plant communities (the names of vascular plants are given according to World Flora Online, 2012), five forest sites (FS) were identified where faunal and quantitative earthworm recordings were performed (henceforth FS 1-5):

FS 1. Kedrovaya Pad Nature Reserve - valley fir-cedar (Abies nephrolepis (Trautv. ex Maxim.) Maxim., Pinus koraiensis Siebold \& Zucc.) broad-leaved forest with ferns
(Dryopteris crassirhizoma Nakai) and dead cover (about 50\%); $101 \mathrm{~m}$ above sea level.

FS 2. Ussuri Nature Reserve, Komarovskoye forest district and Turov Hill - cedar (Pinus koraiensis) broadleaved forest with sedges (Carex spp.,) and small-herb (Oxalis acetosella L.) in cover; hillside forest $(207 \mathrm{~m}$ above sea level).

FS 3. Ussuri Nature Reserve, Komarovskoye forest district and Grabovaya Hill (slope). Fir-hornbeam (Abies nephrolepis) forest with dead cover (about 80\%) and smallherb (Oxalis acetosella); hillside forest (350 $\mathrm{m}$ above sea level).

FS 4. Ussuri Nature Reserve, Suvorov forest district and Anikin river valley - valley forest with elm (Ulmus japonica (Rehder) Sarg.), ash (Fraxinus mandshurica Rupr.) and cedar (Pinus koraiensis) with cover of ferns (Athyrium sinense Rupr, Dryopteris crassirhizoma, Hylomecon vernalis Maxim.) and tall-herbs (Impatiens noli-tangere L., Cardamine leucantha (Tausch) O.E.Schulz)); $156 \mathrm{~m}$ above sea level.

Forest sites 1-4 are the best-preserved forests, with no traces of logging and fires over the last century.

FS 5. Komsomolsky Nature Reserve and Gorin river valley - valley cedar (Pinus koraiensis) broad-leaved forest with a cover of ferns (Leptorumohra amurensis Tzvelev) and small-herbs (Maianthemum bifolium (L.) F.W. Schmidt, Viola sacchalinensis H. Boissieu, Cornus canadensis L., Waldsteinia ternata subsp. trifolia (Rochel ex W.D.J. Koch) Teppner); $239 \mathrm{~m}$ above sea level. This site was partially cut down and affected by fires in recent decades.

The soil type of all the surveyed test plots (sites) is forest brown soil with a well-defined horizon of litter (4 to $10 \mathrm{~cm}$ ) from mixed leaf litter of coniferous and deciduous species of trees and shrubs.

\section{Materials and Methods}

The material was collected during the summers (July-August) of 2016-2018. To evaluate diversity and spatial distribution of earthworms, we used fractal design that allows assessing the distribution parameters of groups of organisms at different spatial levels; this method was developed by A.I. Azovsky to count collembolans (Saraeva et al., 2015) and was adapted for earthworms (Geraskina \& Kuznetsova, 2017).

In each forest type (forest site), one series of 27 soil samples $(10 \times 10 \mathrm{~cm})$ was taken, depth $-30 \mathrm{~cm}$. Each set of samples includes three groups (nine samples in one group), at a distance of $10 \mathrm{~m}$ from each other. Each group includes three subgroups (three samples in one subgroup), at a distance of $20 \mathrm{~cm}$ from each other. The distance between individual samples within subgroups is $5 \mathrm{~cm}$ (Fig. 3). The 


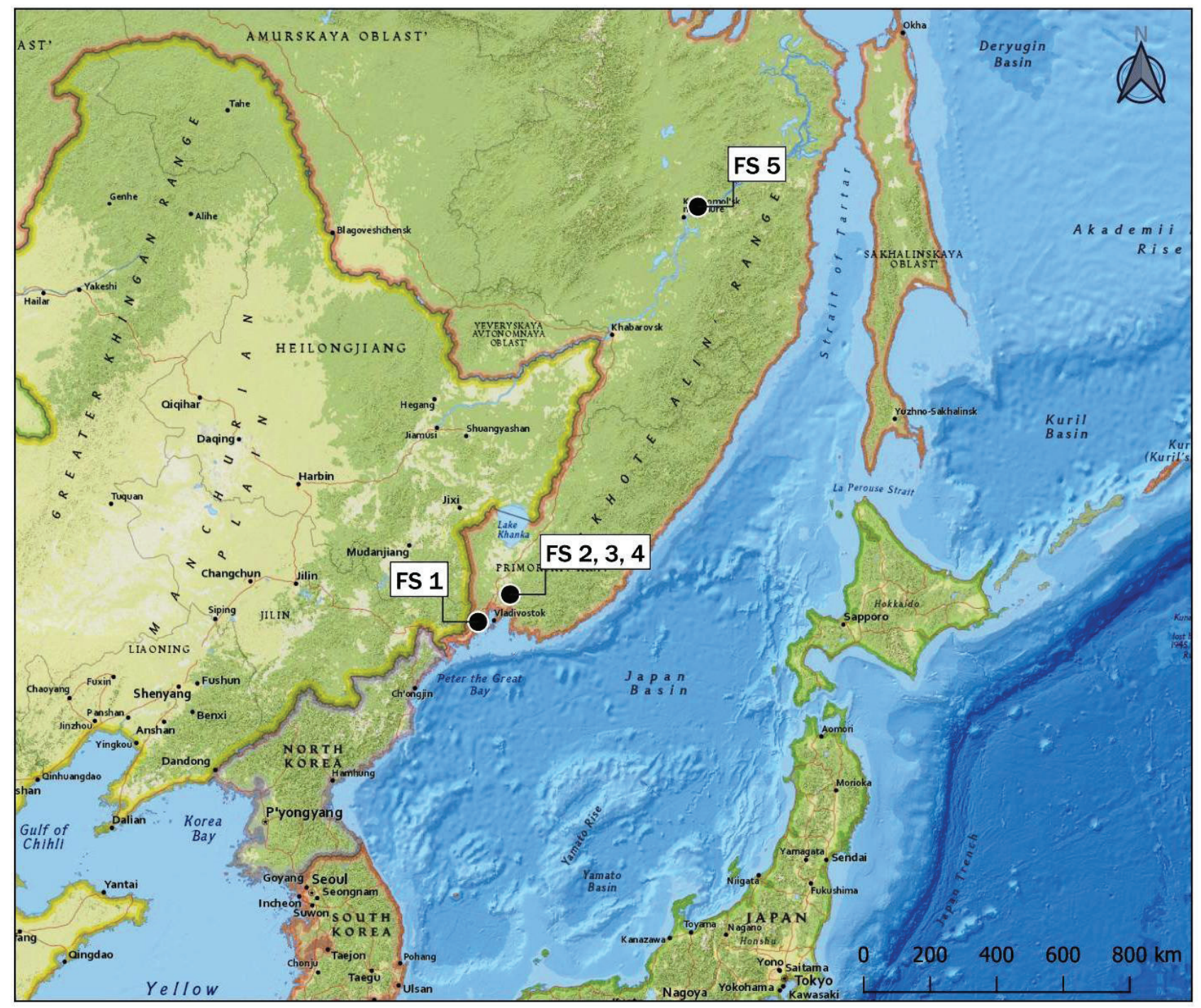

Figure 1. The map of the test plots. Note: FS 1 - Kedrovaya Nature Pad Reserve, FS 2, 3 and 4 - Ussuri Nature Reserve, FS 5 Komsomolsky Nature Reserve

abundance and biomass of earthworms are calculated per $\mathrm{m}^{2}$. The Casey Index was calculated to assess the spatial distribution within $1 \mathrm{~m}^{2}$ and the degree of aggregation of individuals: $\mathrm{Ic}=\left(\mathrm{S}^{2}-\mathrm{M}\right) / \mathrm{M}^{2}$, where $\mathrm{M}$ is the average species abundance and $\mathrm{S}^{2}$ the dispersion. At Ic $<0$ the distribution is uniform, at Ic $=0$ it is random and at Ic $>0$ it is aggregated (Saraeva et al., 2015).

Spatial distribution of the types of individuals can be convincingly evaluated only if the species abundance has at least one specimen per sample (Saraeva et al., 2015). Due to the fact that the obtained data on abundance of almost all species was lower than this, we considered the spatial distribution of the most numerous groups, i.e. epiendogeic and endogeic species.
In addition to quantitative assessment, faunal collections of earthworms in dead wood of coniferous and deciduous tree species at decomposition stages 2-3 (Ashwood et al., 2019) were carried out in the valley forests of FS 4 and FS 5.

Soil parameters, i.e. soil temperature, humidity and acidity (assessed with PH 300 electronic soil indicator) were measured in the studied forest types. During the accounting periods, the temperature of the litter horizon ranged from 13 to $17^{\circ} \mathrm{C}$, the mineral horizon from 10 to $15^{\circ} \mathrm{C}$ and the $\mathrm{pH}$ from 5.5 to 6.5 . As for moisture, the soil of the studied territories is usually moderately moist: 30 $40 \%$ in hillside forests (FS 2-3) or humidity excesses 40 $50 \%$ in valley forests (FS 1, 4, 5). 

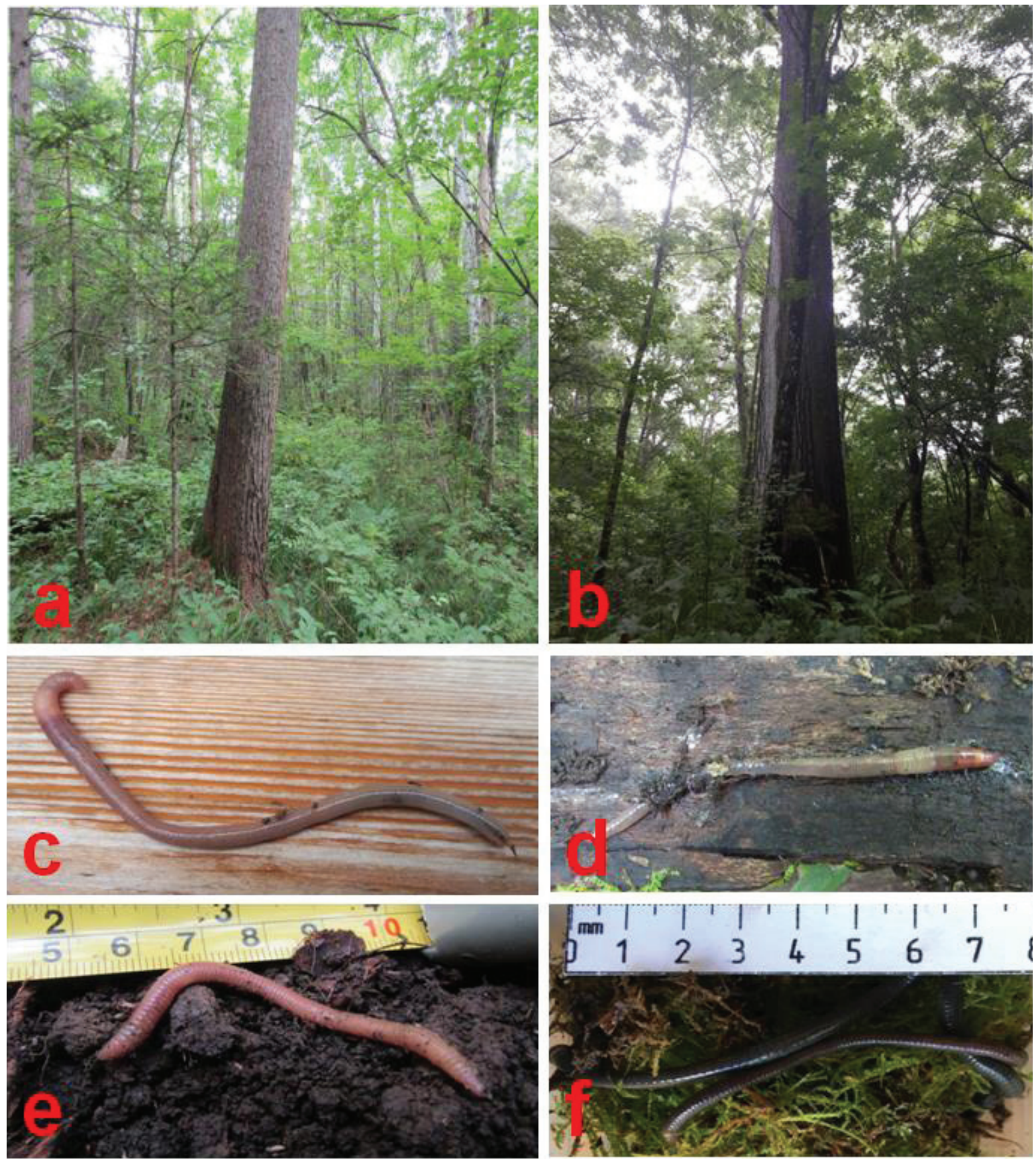

Figure 2. Pictures of forest habitats and different earthworms' species. Note: a - Komsomolsky Nature Reserve, b - Ussuri Nature Reserve, c - Eisenia nordenskioldi, d - Octolasion lacteum, e - Eisenia sp. (juv.), f - Drawida ghilarovi

Earthworms were placed in $96 \%$ ethyl alcohol. The biomass of earthworms was determined by weighing the fixed earthworms with a full gut. The species composition and functional groups of earthworms were established by Cadastre from the Fauna of Russia (Vsevolodova-Perel, 1997). When comparing samples, the Kruskall-Wallis test was used to identify significant differences $(p<0.05)$.

\section{Results and discussion}

\subsection{Taxonomic and functional diversity} of earthworms

In the course of research, nine species of earthworms, belonging to two families and four functional groups, were 


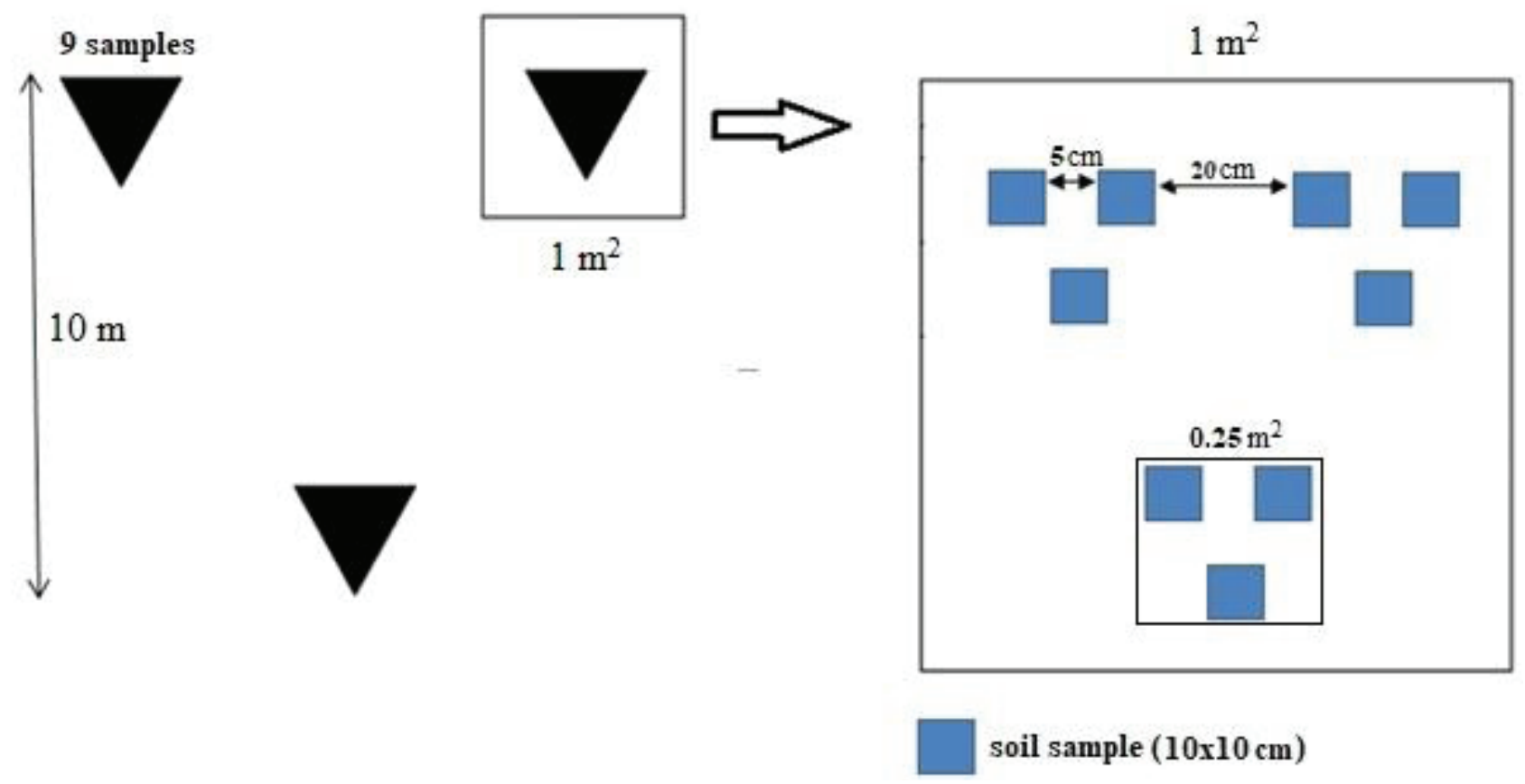

Figure 3. Fractal design for assessing the horizontal earthworm distribution (Saraeva et al., 2015, Geraskina \& Kuznetsova, 2017)

found in the polydominant forests in the southern Far East (Table 1). The Lumbricidae family includes eight species, of which six are cosmopolitans (epigeic - Dendrobaena octaedra (Savigny, 1826), Dendrodrilus rubidus tenuis (Eisen, 1874); epi-endogeic Lumbricus rubellus Hoffmeister, 1843; endogeic Aporrectodea caliginosa (Savigny, 1826), Aporrectodea rosea (Savigny, 1826) and Octolasion lacteum (Örley, 1881), as well as two species with limited range (epi-endogeic Eisenia nordenskioldi nordenskioldi (Eisen, 1879)) with the range in the eastern regions of the European part of Russia and Ukraine, Siberia, the Far East and the East Asian species Eisenia nordenskioldi pallida Malevič 1956. The Moniligastridae family includes one species Drawida ghilarovi Gates, 1969 (endemic to the southern Far East), which is represented by two functional groups and various colour morphs: epi-endogeic (black morph) and anecic (grey, brown and greenish-blue morphs) (Ganin \& Atopkin, 2018).

The largest species diversity of earthworms was found in the valley fir-cedar-broad-leaved forest in the Kedrovaya Pad Reserve (FS1) which is home to six species of Lumbricidae and two forms of $D$. ghilarovi species (Moniligastridae), i.e. epi-endogeic - black morph and anecic - brown morph. The composition of the functional groups of earthworms is full. However, the biomass and abundance of earthworms are significantly lower here than in the forests of the Ussuri Reserve (FS 2 and 4) (Table 1; Fig. 4). That said, we have not conducted surveys of ad- ditional earthworm habitats other than soil excavations in this area, therefore, the potential taxonomic diversity may be higher.

The largest abundance and biomass of earthworms were identified in this study and the entire spectrum of functional groups was represented in the valley elm-ashcedar forest of the Anikin river valley (FS 4). The functional structure is dominated by the endogeic species group (Fig. 4). The polymorphic species $D$. ghilarovi is represented by two forms, i.e. epi-endogeic and anecic, while earthworms of three colour morphs are found amongst anecic forms: grey, brownish and bluish-green. During the survey of Maximovich poplar dead wood (decomposition stage 3 ) and Korean pine (decomposition stage 2), D. octaedra, $D$. r. tenuis and a black morph of D. ghilarovi were found. The complex phytocenotic structure of this valley forest, with a diverse composition of forest-forming species, also supports the abundance and unique diversity of xylobiont beetles and other insects included in the Red List of Russia and neighbouring countries (China, The Republic of Korea): Callipogon relictus Semenov, 1899; Rosalia coelestis Semenov, 1911; Osmoderma davidis Fairmaire, 1887; Carabus (Acoptolabrus) constricticollis Kraatz, 1886 (Coleoptera); Apis cerana Fabricius, 1793; and Liometopum orientale Karavaiev, 1927 (Hymenoptera) (Kuprin, 2012; Kuprin, 2016; Kuprin \& Drumont, 2016; Kuprin \& Yi, 2019; Lee et al., 2018). Therefore, this polydominant valley forest can be considered as the most promising one for 
complex ecological studies of the most preserved forest ecosystems of Southern Primorye and for studying the relationships between different biota components.

The least diversity, abundance and biomass of earthworms (Table 1; Fig. 4) were identified in valley cedarbroad-leaved forest in Komsomolsky Reserve (FS 5): only epigeic and epi-endogeic earthworms were found here. The anecic group and soil group, as such, were lacking. In total, four earthworm species were identified when soil samples and the dead wood survey were taken into account.

Incomplete composition of the earthworm groups was also found in the hillside forests: cedar-broad-leaved forest (FS 2) and fir-hornbeam forest (FS 3). No epigeic or endogeic species were found here. Epi-endogeic E. $n$. nordenskioldi and E. n. pallida predominate in terms of abundance and biomass which are the typical species for polydominant forests of southern Far East (Perel, 1979; Vsevolodova-Perel \& Leirikh, 2014).

The available data on the earthworm population of Southern Primorye, obtained mainly from the survey of black fir forests in the Ussuri Reserve and the mixed forests of the Kedrovaya Pad Reserve (Gilyarov \& Perel, 1973; Perel, 1979) show that, generally, we have identified no potential species diversity of earthworms, either within local forest territories (for which a number of cosmopolitan species of the Lumbricidae fam. was also listed) or in the south of the Russian Far East in general, for which at least 16 earthworms species of four families have been specified (Ganin, 2011). At the same time, the results on the earthworms' abundance and biomass obtained by us are quite high, especially in the valley elm-ash-cedar forest with fern - tall-herb cover (FS 4). According to literature, these indicators are usually 2-3 times lower in mixed forests (Gilyarov \& Perel, 1973; Vsevolodova-Perel \& Leirikh, 2014). Unusually high quantitative indicators of the abundance and biomass of earthworms in this forest type are due to moist (often waterlogged) soils; it is also evidenced by the prevalence of $O$. lacteum species which is an indicator of waterlogged biotopes (Perel, 1979) and good trophic conditions with mixed litter fall and easily decomposable fractions of linden, poplar, ash, maple leaves etc. However, despite similar moisture conditions, as well as other comparable trophic and topological conditions (soil type, mixed litter fall, $\mathrm{pH}$ ), the valley cedar-broadleaved forest of the Gorin river valley (FS 5) showed the lowest abundance, biomass and diversity of earthworms. These differences are most likely caused by other factors impacting on soil biota, i.e. more frequent fires in Komsomolsky Reserve and the economic activity (logging) mode, including before the creation of the Nature Reserve in 1963 (Kuberskaya \& Novomodnyi, 2019), the consequences of which do not allow soil fauna to restore and sustainably to develop.

\subsection{Patterns of spatial distribution of earthworms}

Spatial distribution of earthworms is partially described by species occurrence rate within the study area. Epigeic and anecic species show the lowest occurrence in samples of all the studied communities (under $15 \%$ of samples); at the same time, these species were not detected in a number of communities. Plant communities with the occurrence of other functional groups of earthworms (epi-endogeic and endogeic) reaching $80-100 \%$ may be identified. In this regard, the horizontal spatial distribution types were analysed for these two groups: the distribution of epi-endogeic species was studied within three test plots (FS 2, 3 and 4) and the distribution of endogeic species was studied within two test plots (FS 1 and 4).

Casey index values for epi-endogeic species on $0.25 \mathrm{~m}^{2}$ sites was close to zero $(+0.5$ to -0.5$)$ and, on $1 \mathrm{~m}^{2}$ to 100 $\mathrm{m}^{2}$ sites, it was below zero (0 to -1.6) (Fig. 5). This type of distribution is a sign of absence of aggregations and is defined as "covering" (Saraeva et al., 2015) or regular distribution without aggregation (Whalen, 2004).

Casey index values for endogeic species on $0.25 \mathrm{~m}^{2}$ to $100 \mathrm{~m}^{2}$ sites are positive (from 0.5 to 2.5 ), i.e. the distribution of these species tends to form aggregations (Fig. 6). Since there are three levels of aggregation of these species, this type of spatial distribution is defined as "spotty" (Saraeva et al., 2015) or aggregated distribution (Whalen, 2004). The largest clusters may be identified within 0.25 $\mathrm{m}^{2}$ and $1 \mathrm{~m}^{2}$ plots, whereas the smallest ones were found on $100 \mathrm{~m}^{2}$ plots. There are few studies of the horizontal spatial distribution of earthworms in world literature (Pauli et al., 2010; Gutierrez-Lopez et al., 2010; Jimenez et al., 2014) and the available data show that the groups' distribution is usually unstable, season-dependent and is very often determined by the level of soil moisture and the distribution of trophic resources (Pauli et al., 2010). In our conditions, in the studied forest types, the distribution was evaluated on levelled sites with a uniform litter horizon and evenly moistened soil, so this distribution pattern can probably be explained by the peculiarities of the habitat and travelling of functional groups. Epi-endogeic species feed in the litter horizon and travel over the soil surface more actively, so their distribution type tends more to "covering" or regular distribution without aggregation; endogeic species are more dependent on the mineral horizons of the soil, their migration over large areas is limited, individual samples often containing a mature individual and several juvenile earthworms of different sizes (and age) who live together with mature earthworms and are probably unable to travel for long distances over a long period. 


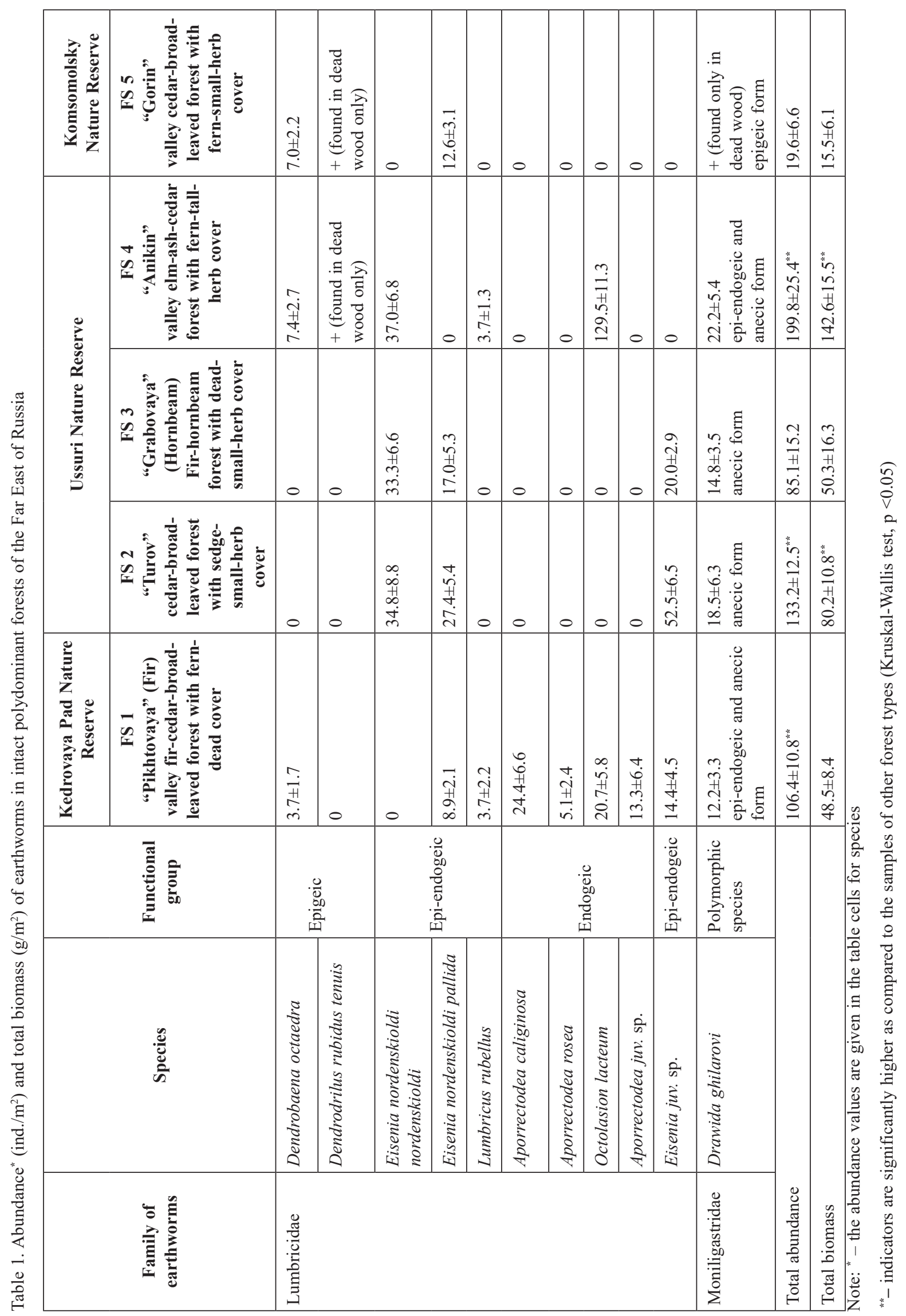



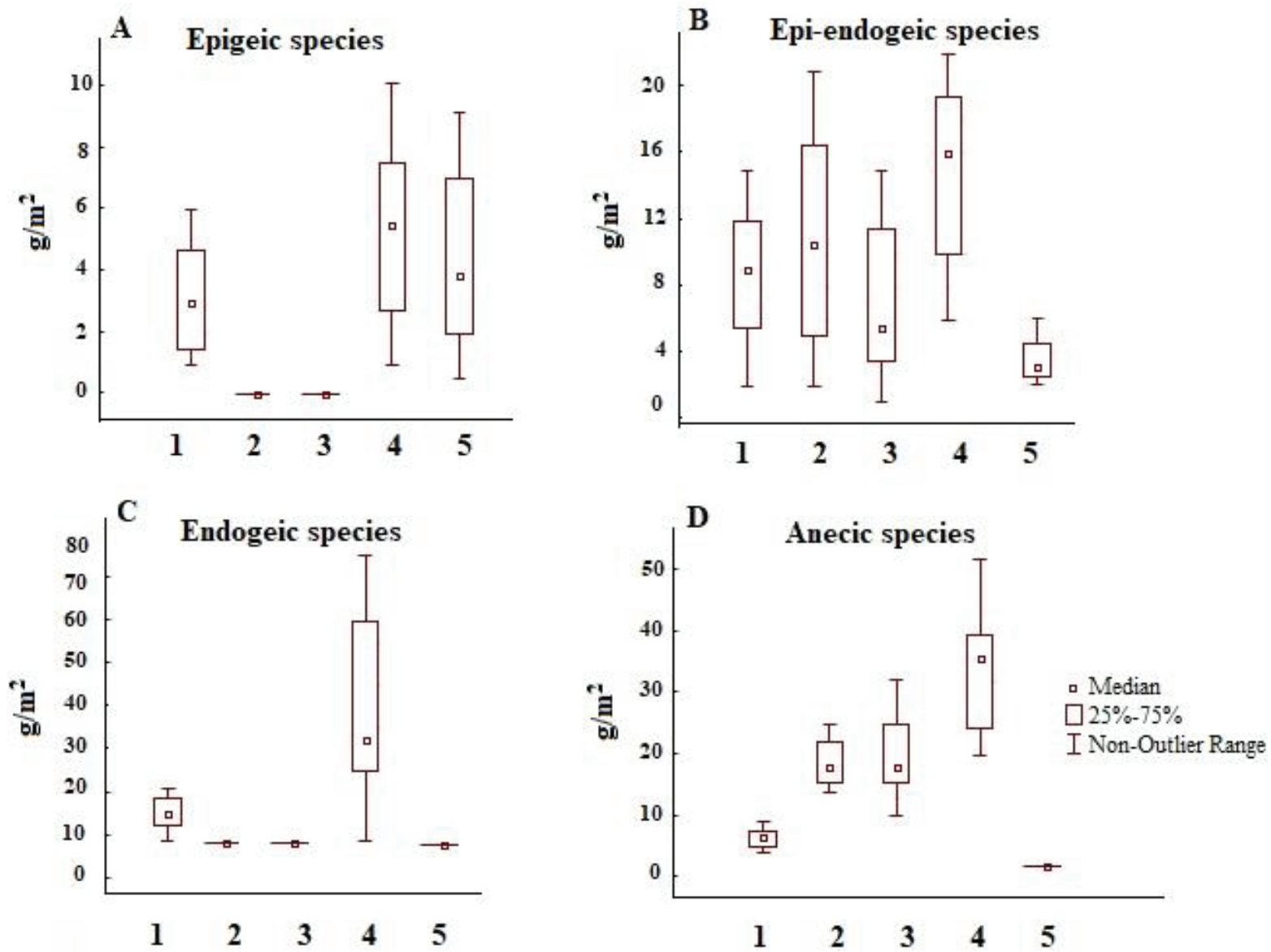

Figure 4. Biomass of functional groups of earthworms in polydominant forests of Southern Primorye (1-5 are numbers of test plots as in Table 1)



Figure 5. Casey index values for the epi-endogeic species group distribution 


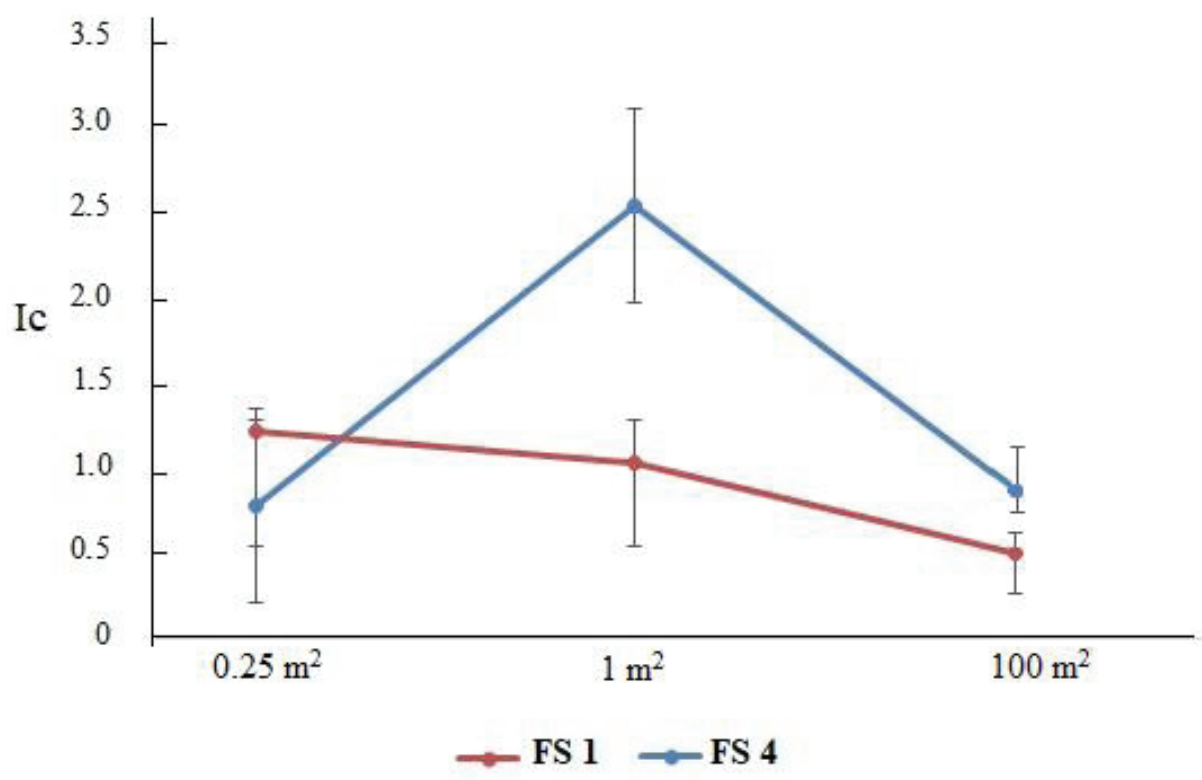

Figure 6. Casey index values for the endogeic species group distribution

\section{Conclusions}

One of important criteria for the assessment of earthworm population is the functional diversity of the heterogeneous composition of the functional group of these saprophages. The most complete set of functional groups of earthworms was only found in two valley forests amongst the studied polydominant forests: Kedrovaya Pad Reserve and in the valley of the Anikin River (Ussuri Reserve). These forests are home to epigeic, epi-endogeic, endogeic and anecic species. Epigeic and endogeic species were not found in hillside forests of the Ussuri Reserve (Turov Hill, Grabovaya Hill).

No endogeic or anecic species were found in the valley section of the Komsomolsky Reserve (Gorin river valley), despite a detailed survey of different habitats (dead wood, micro-depressions etc.), which is a sign of serious disturbances of these ecosystems that occurred in the past. The main reasons are most probably associated with considerable anthropogenic impact on these forests and their poorer preservation as compared to other studied territories, because, in general, the floral diversity of the main forest-forming species, mixed litter fall, the intensity of soil horizons, good moisture (including in summer seasons) and the presence of dead wood, form potentially favourable habitats for different groups of earthworms.

Horizontal spatial distribution was analysed for the dominating groups of earthworms in terms of biomass and occurrence, i.e. epi-endogeic and endogeic. Plots of different sizes have shown the "covering" type of distribution for the epi-endogeic species, i.e. these species do not show a tendency to form aggregations in homogeneous conditions, but are spread evenly. On the contrary, the endogeic species have shown the "spotty" type of distribution, i.e. these species have a tendency to form aggregations.

\section{Acknowledgements}

This work was supported by the programme "Methodical approaches to the assessment of the structural organization and functioning of forest ecosystems" No. AAAA-A18-118052590019-7. The authors are sincerely grateful to M. Potapov, N. Kuznetsova and O. Kuberskaya for their organising research and great assistance in collecting material.

\section{References}

Ashwood F., Vanguelova E.I., Benham S. \& Butt K.R., 2019, Developing a systematic sampling method for earthworms in and around deadwood. Forest Ecosystems 6: 1-12. https://doi.org/10.1186/s40663-0190193-z

Buckingham S., Murphy N. \& Gibb H., 2019, Effects of fire severity on the composition and functional traits of litter-dwelling macroinvertebrates in a temperate forest. 
Forest Ecology and Management 434: 279-288. https:// doi.org/10.1016/j.foreco.2018.12.030

Dunger W. \& Voigtländer K., 2005, Assessment of biological soil quality in wooded reclaimed mine sites. Geoderma 129: 32-44. https://doi.org/10.1016/j.geoderma.2004.12.028

Dunger W., Wanner M., Hauser H., Hohberg K., Schulz H.J., Schwalbe T., Seifert B., Voigtländer K., Zimdars B. \& Zulka K.P., 2001, Development of soil fauna at mine sites during 46 years after afforestation. Pedobiologia 45: 243-271. https://doi.org/10.1078/0031-4056-00083

Easton E.G., 1981, Japanese earthworms: a synopsis of the Megadrile species (Oligochaeta). Bull. Br. Mus. Nat. Hist. (Zool.). 40: 33-65.

Ganin G.N., 2011, Strukturno-funkcional'naja organizacija soobshhestv mezopedobiontov juga Dal'nego Vostoka Rossii [Structural and functional organization of mezopedobiont communities of the Southern Russian Far East]. Dalnauka, Vladivostok, 380 pp.

Ganin G.N. \& Atopkin D.M., 2018, Molecular differentiation of epigeic and anceic forms of Drawida ghilarovi Gates, 1969 (Moniligastridae, Clitellata) in the Russian Far East: Sequence data of two mitochondrial genes. European Journal of Soil Biology 86: 1-7.

Geraskina A.P. \& Kuznetsova N.A., 2017, Osobennosti prostranstvennogo mikroraspredelenija pochvennyh zhivotnyh v gornyh sosnovyh lesah Kavkaza [Features of the spatial microdistribution of soil animals in the mountain pine forests of the Caucasus]. Materials VI All-Russian conference. "Mountain ecosystems and their components", ALEF, Makhachkala, pp. 96-97.

Gilyarov M.S. \& Perel T.S., 1973, Kompleksy pochvennyh bespozvonochnyh hvojno-shirokolistvennyh lesov Dal'nego Vostoka kak pokazatel' tipa ih pochv [Complexes of Soil Invertebrates in Conifer-Broad-Leaved Forests of the Far East as Indicators of the Soil Types]. Ecology of Soil Invertebrates. Nauka, Moscow, pp. 4059.

Gutierrez-Lopez M., Jesus J.B., Trigo D., Fernandez R., Novo M. \& Diaz-Cosin D.J., 2010, Relationships among spatial distribution of soil microarthropods, earthworm species and soil properties. Pedobiologia 53: 381-389. https://doi.org/10.1016/j.pedobi.2010.07.003

Hüttl R.F. \& Weber E., 2001, Forest ecosystem development in post-mining landscapes: a case study of the Lusatian lignite district. Naturwissenschaften 88: 322329. https://doi.org/10.1007/s001140100241

Jimenez J.J., Decaens T., Lavelle P. \& Rossi J.P., 2014, Dissecting the multi-scale spatial relationship of earthworm assemblages with soil environmental variability. BMC Ecology 14: 26. https://doi.org/10.1186/s12898014-0026-4

Kozhevnikov A.E. \& Kozhevnikova Z.V., 2014, Taksonomicheskij sostav i osobennosti prirodnoj flory Pri- morskogo kraja [Taxonomic composition and features of the natural flora of the Primorsky Territory]. Komarovskie Chtenija 62: 7-62.

Kuberskaya O.V. \& Novomodnyi E.V., 2019, Istorija jentomologicheskih issledovanij v Komsomol'skom zapovednike Habarovskogo kraja [The history of entomological research in the Komsomolsky Nature Reserve, Khabarovsk territory]. Chteniya pamyati A.I. Kurencova 30: 39-50. https://doi.org/10.25221/kurentzov.30.3

Kuprin A.V., 2012, Jekologija i biologija zhestkokrylyh (Coleoptera) v dolinnyh lesah Ussurijskogo zapovednika [Ecology and biology of Coleoptera in the valley forests of the Ussuriisky Reserve]. PhD Dissertation in Biology. Biological and Soil Institute of the Far Eastern Branch of the Russian Academy of Sciences, Vladivostok, 153 pp.

Kuprin A.V., 2016, The longicorn beetles (Insecta, Coleoptera: Cerambycoidae) of the Ussuri Nature Reserve and adjacent territories. Far Eastern Entomologist 309: 21-28.

Kuprin A.V. \& Bezborodov V.G., 2012, Areal of Callipogon relictus Semenov, 1899 (Coleoptera, Cerambycidae) in the Russian Far East. Biology Bulletin 39: 387391. https://doi.org/10.1134/S1062359012030090

Kuprin A.V. \& Drumont A., 2016, Stratification and diversity of beetles (Insecta, Coleoptera) in native elm forests of the Ussuri Nature Reserve, Russia. Entomology and Applied Science Letters 3: 1-8.

Kuprin A.V. \& Kharchenko V.A., 2013, Spatial distribution of Coleoptera (Insecta) in the valley forests of the Ussuri Nature Reserve (South Primorye, Russia). Open Journal of Ecology 3: 464-468. http://dx.doi. org/10.4236/oje.2013.37053

Kuprin A.V. \& Yi D.A., 2019, Spatial and vertical distribution of longicorn beetles (Coleoptera, Cerambycidae) in the forests of the southern part of the Primorsky Territory. Russian Journal of Ecosystem Ecology 4: 1-15. https://doi.org/10.21685/2500-0578-2019-1-3

Kuznetsova N.A., Bokova A.I., Saraeva A.K. \& Shveenkova Y.B., 2019, Communities of Collembola in the forests of Southern Primorye as a benchmark of high diversity and organization complexity. Biology Bulletin 46: 483-491. https://doi.org/10.1134/S1062359019050066

Lee S.G., Kim C., Kuprin A.V., Kang J.H., Lee B.W., Oh S.H. \& Lim J., 2018, Survey research on the habitation and biological information of Callipogon relictus Semenov (Coleoptera, Cerambycidae, Prioninae) in Gwangneung Forest, Korea and Ussurisky Nature Reserve, Russia. Zookeys 792: 45-68. https://10.3897/ zookeys.792.26771

Mikhaleva E.V., 2017, Fauna dvuparnonogih mnogonozhek (Diplopoda) Aziatskoj chasti Rossii [Fauna of twolegged millipedes (Diplopoda) of the Asian part of Russia]. Dalnauka, Vladivostok, 336 pp. 
Mordkovich V.G. \& Lyubechanskii I.I., 2019, Ground Beetles (Coleoptera, Carabidae) and Zoodiagnostics of ecological succession on technogenic catenas of brown coal dumps in the KAFEC area (Krasnoyarsk Krai). Biology Bulletin 46: 500-509. https://doi.org/10.1134/ S106235901905008X.

Naumov J.A., 2012, Istorija zarozhdenija i razvitija jekologicheskih problem v Primorskom Krae v doindustrial"nuju jepohu (ot paleolita do xix veka) [The history of the emergence and development of environmental problems in the Primorsky Territory in the pre-industrial era (from the Paleolithic to the nineteenth century)]. Problemy paleojekologii i istoricheskoj geojekologii. Saratov State Technical University, Saratov, pp. 175-183.

Pauli N., Oberthür T., Barrios E. \& Conacher A.J., 2010, Fine-scale spatial and temporal variation in earthworm surface casting activity in agroforestry fields, western Honduras. Pedobiologia 53: 127-139. https://doi. org/10.1016/j.pedobi.2009.08.001

Perel T.S., 1979, Rasprostranenie i zakonomernosti raspredelenija dozhdevyh chervej fauny SSSR [Distribution of earthworms in the fauna of the USSR]. Nauka, Moscow, $272 \mathrm{pp}$.

Prescott C.E., Frouz J., Grayston S.J., Quideau S.A. \& Straker J., 2019, Rehabilitating forest soils after disturbance. Developments in Soil Science 36: 309-343. https://doi.org/10.1016/B978-0-444-63998-1.00013-6

Ryabinin N.A., 2011, Biologicheskoe raznoobrazie pancirnyh kleshhej (Oribatida) Dal'nego Vostoka Rossii [Biological diversity of the beetle mites (Oribatida) of the Russian Far East]. Amurian Zoological Journal 3: 11-15.

Saraeva A.K., Potapov M.B. \& Kuznetsova N.A., 2015, Different-scale distribution of collembola in homog- enous ground vegetation: Stability of parameters in space and time. Entomological Review 95: 699-714. https://doi.org/10.1134/S0013873815060032.

Smirnova O.V. \& Toropova N.A., 2016, Potential ecosystem cover - a new approach to conservation biology. Russian Journal of Ecosystem Ecology 1: 1-20. https:// doi.org/10.21685/2500-0578-2016-1-1.

Starozhilov V.T., 2010, Landscape zonation of Primorsky Krai. Bulletin of the Far Eastern Branch of the Russian Academy of Sciences 3: 107-112. https://doi. org/10.4236/gep.2018.612015.

Vsevolodova-Perel T.S., 1997, Dozhdevye chervi fauny Rossii: kadastr i opredelitel' [Earthworms of the fauna of Russia: Cadastre and determinant]. Nauka, Moscow, $101 \mathrm{pp}$.

Vsevolodova-Perel T.S. \& Leirikh A.N., 2014, Distribution and ecology of the earthworm Eisenia nordenskioldi pallida (Oligochaeta, Lumbricidae) dominant in Southern Siberia and the Russian Far East. Entomological Review 94: 479-485. https://doi.org/10.1134/ S0013873814040034.

Whalen J.K., 2004, Spatial and temporal distribution of earthworm patches in corn field, hayfield and forest systems of southwestern Quebec, Canada. Applied Soil Ecology 27: 143-151. https://doi.org/10.1016/j. apsoil.2004.04.004

Wikars L.O. \& Schimmel J., 2001, Immediate effects of fire-severity on soil invertebrates in cut and uncut pine forests. Forest Ecology and Management 141: 189-200. https://doi.org/10.1016/S0378-1127(00)00328-5.

World Flora Online, 2012, online version at http://www. worldfloraonline.org/ [Accessed: 12.11.2020)]. 



\title{
The role of canopy gaps in maintaining biodiversity of plants and soil macrofauna in the forests of the northwestern Caucasus
}

\author{
Nikolaj Shevchenko ${ }^{1}$, Anna Geraskina ${ }^{1 *}$, Alexander Kuprin², Evgeniy Grabenko ${ }^{3}$ \\ ${ }^{1}$ Center for Forest Ecology and Productivity Russian Academy of Sciences, Moscow, Russian Federation \\ ${ }^{2}$ Federal Scientific Center of the East Asia Terrestrial Biodiversity, Far Eastern Branch Russian Academy of Sciences, \\ Vladivostok, Russian Federation \\ ${ }^{3}$ Institute of Geography Russian Academy of Sciences, Russian Federation \\ "corresponding author e-mail: angersgma@gmail.com
}

Received: 23 April 2020 / Accepted: 23 December 2020

\begin{abstract}
The research was carried out in the coniferous-deciduous forests of the northwestern Caucasus, growing in similar climatic and soil-orographic conditions. Three types of forests of different ages were studied: aspen-hornbeam (50-70 years), beech-firhornbeam (80-110 years) and fir-beech forests (over 450 years). The studies were performed on the territory Krasnodar Krai (upper reaches of the Pshekha river, State Nature Reserve Chernogor'e) and the Republic of Adygea (upper reaches of the Belaya river, the Caucasian State Biosphere Reserve) in the summer seasons 2016 and 2019. The research involves geobotanical, population-ontogenetic, and soil-zoological methods. It has been established that in the canopy gaps of all forest types species density of plants is almost twice as high as in under-crown areas or even higher due to good light factor and high soil moisture since the tree stand does not intercept precipitation. Regeneration of tree cenopopulations in all forest types is much more effective in canopy gaps compared to under-crown areas. The undergrowth density of different types of trees is 10 and more times higher in gaps than in the under-crown areas. The maximum number of ecological-coenotic groups of plants is observed in the canopy gaps in all types of forest. All major trophic groups of macrofauna inhabit canopy gaps and under-crown areas, but their biomass in gaps is significantly exceeds that in under-crown areas. Due to the fact that soil moisture supply is an essential factor for moisture-loving saprophages' activity, biomass of saprophages is on average twice as high in gaps than under-crown areas of all forest types. Only canopy gaps have high biomass of anecic earthworms - there are important ecosystem engineers, which contribute a lot to plant litter processing and the formation of soil porosity.
\end{abstract}

Keywords: earthworms, forest community, invertebrates, species richness, treefall gaps, trophic groups, saprophages, under-crown area, undergrowth.

\section{Introduction}

Gap dynamics model defines the self-support capabilities of forests (Watt, 1947; Oldeman, 1983; Whitmore, 1990). In this model, forests are shown as a mosaic of spots of different ages with a continuous change in the vegetation species composition. It has been shown that the canopies of various tree species can act as ecological filters (Gandolfi et al., 2007) for vegetation renewal. There are obvi- ous differences in the conditions for plant growth under the canopy of deciduous and coniferous tree species. However, drastic changes in the light and precipitation mode occur after the fall of old trees and canopy gaps formation. Great attention is currently being paid to the role of canopy gaps in maintaining biological (Bartemucci et al., 2002) and structural diversity (Zhang et al., 2013; Muscolo et al., 2014) of forest communities and application this knowledge in forest management practices (Vajari et al., 2012; 
Yamamoto, 1996; Rebertus \& Veblen, 1993; Runkle, 2000; Haghverdi et al., 2012; etc.). The area of natural canopy gaps according to literature can range from 200 to $5.000 \mathrm{~m}^{2}$ (Muscolo et al., 2014), the average gap size for Eastern European forests is between 200 and $600 \mathrm{~m}^{2}$ (Smirnova et al., 2004). It has been shown that gap size also determines the structural and functional diversity of the soil macrofauna (Kooch \& Hosseini, 2010; Kooch \& Haghverdi, 2014), particularly that of soil saprophages, which act as a driver of litter decay. Assessing of and forecasting the sustainable development of forest ecosystems requires linked studies of transformation of vegetation and large soil macrofauna that mediates the influence of vegetation on soil properties through the quality of litter (Frouz et al., 2013). Due to the fact that undercrown spaces and gaps differ in light factor and the amount of precipitation, it can be assumed that the diversity and composition of functional groups of plants and soil macrofauna will differ between these structural elements. The diversity of some plant and invertebrate groups can be expected to be higher in gaps than under canopy.

The objective of the work is to assess the contribution of gaps to the maintenance of structural and biological diversity of vegetation and soil macrofauna of mixed coniferous-broad leaved forests of the northwestern Caucasus.

\section{Study area}

The research was carried out in the upper reaches of the Pshekha river (Krasnodar Krai) and the Belaya river (Republic of Adygea, Caucasian State Biosphere Reserve) (Fig. 1). This territory is part of the Western mountain province of the Greater Caucasus (Gvozdetsky, 1963; Milkov \& Gvozdetsky, 1986). Average annual precipitation is $1.200 \mathrm{~mm}$. Average annual temperature is $+10.3^{\circ} \mathrm{C}$. Positive air temperatures remain for 292-361 days, and the growth season $\left(\mathrm{T}>10^{\circ} \mathrm{C}\right)$ is $160-234$ days (http://meteo.ru). The relief is complex: from the pronounced Alpine relief in the upper reaches of the Belaya river, composed of clay shales and limestones, to the relatively flat foothill in the upper reaches of the Pshekha river, composed of clay and crystal shales. High ruggedness of the mountain topography and elevation differences cause vertical variability of all climate indicators. Schist eluvia-based brown soils (Cambisols Dystric, WRB..., 2015) are common in the soil cover. The thickness of the humus horizon is on average $10-15 \mathrm{~cm}$, humus content in the upper horizon can reach $10-15 \%$, $\mathrm{pH}$ is acidic or slightly acidic (Shishov et al., 2004).

In similar climatic and soil-orographic conditions three types of coniferous-deciduous forests of the northwestern Caucasus, i.e. aspen-hornbeam, beech-fir-hornbeam and fir-beech forests, were selected as the object of research (Fig. 2).



Figure 1. Map of the study area and location of forest stands 




1

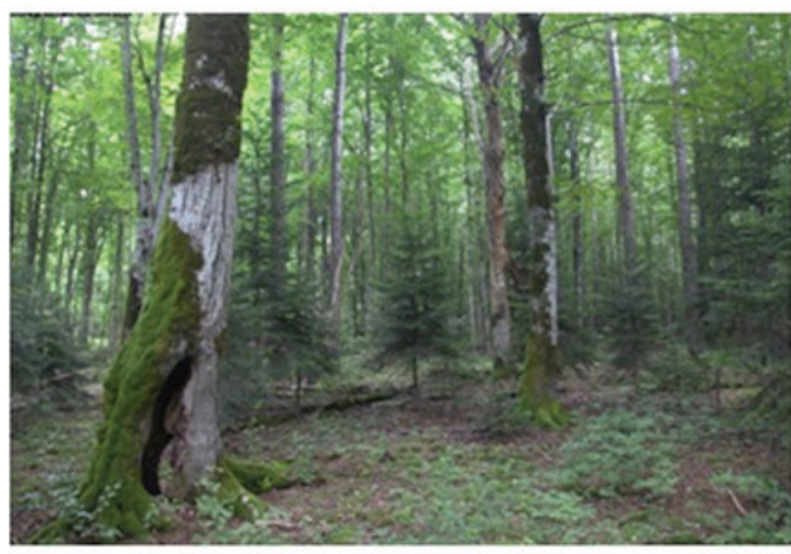

3

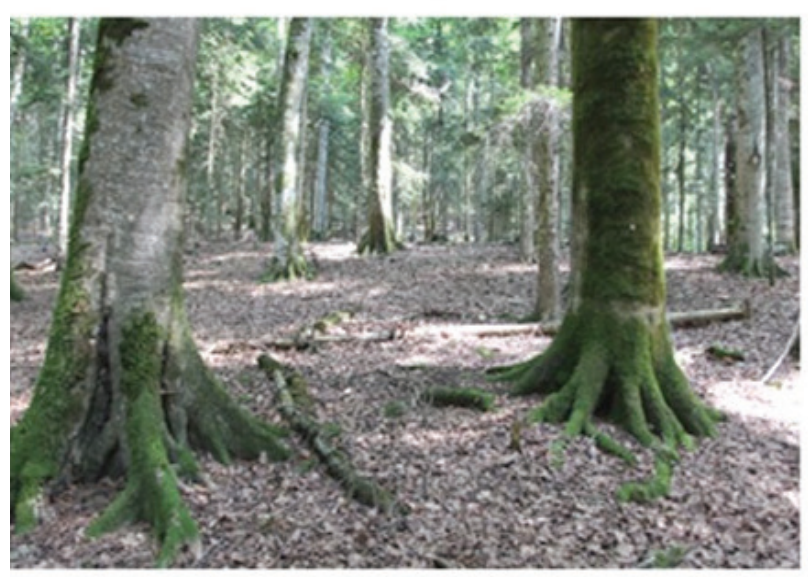

5

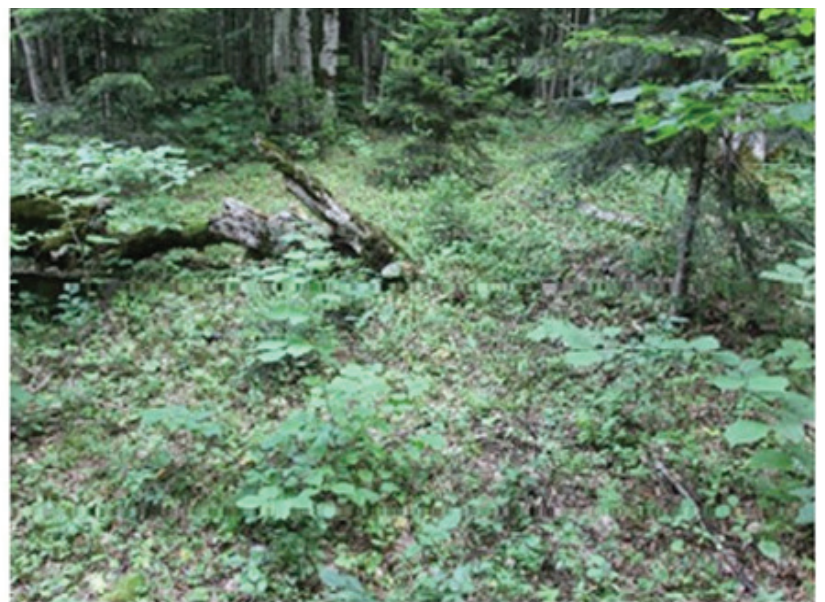

2



4



6

Figure 2. Under-crown areas and canopy gaps of coniferous-deciduous forests of the northwestern Caucasus. Plant communities of: 1 - under-crown area aspen-hornbeam forest type; 2 - canopy gap aspen-hornbeam forest type; 3 - under-crown area beech-fir-hornbeam type of forest; 4 - canopy gap beech-fir-hornbeam type of forest; 5 - under-crown area fir-beech forest type; 6 - canopy gap fir-beech forest type 


\section{Materials and Methods}

\subsection{Characteristics of forest types}

The aspen-hornbeam forest type is formed after clear and selective logging, the maximum age of trees is 50-70 years, the height of the tree canopy is $22 \pm 3.7$ meters, the average stock of stem wood is $293 \pm 34 \mathrm{~m}^{3} / \mathrm{ha}$, of which Carpinus betulus accounts for about $60-75 \%$ of the stock and Populus tremula - for about $10-20 \%$ of the stock, whereas the share of other species is less than 10-5\% (Lukina et al., 2018).

The beech-fir-hornbeam type of forest is formed on the sites of old clear and selective loggings, the maximum age of trees of the first post-harvest generation is $80-110$ years, the height of the stand is $32 \pm 5.7$ meters. The average stock of stem wood is $319 \pm 87 \mathrm{~m}^{3} / \mathrm{ha}$, with Carpinus betulus accounting for $40-50 \%$ of the total wood stock, Abies nordmanniana - for 20-30\% and Fagus orientalis - for $20-25 \%$. In the beech-fir-hornbeam type of forest, there is a gradual loss of light demanding tree species that formed the first post-harvest generation. The upper tree layer includes young shade-tolerant trees of Abies nordmanniana and Fagus orientalis (Lukina et al., 2018).

The fir-beech forest type is characterized by the absence of traces of logging or fire (no coal was found in soil), the tree layer has a complex spatial structure and is represented by trees of different ages. This type of forest was described on the territory of the Caucasian biosphere reserve which has preserved well since the end of the 18th century, so the remaining local forests are the closest to natural ones. The age of individual fir trees exceeds 450 years; the height of the tree canopy reaches $50 \pm 12.1$ meters. The average stock of stem wood is $1.097 \pm 265 \mathrm{~m}^{3} / \mathrm{ha}$, with Fagus orientalis accounting for 66 to $82 \%$ of the total stock of stem wood, and Abies nordmanniana accounting for 16 to $32 \%$ (Lukina et al., 2018).

According to the ecological and floristic classification, these forests belong to different associations of AbietiFagenion orientalis sub-union Korotkov et Belonovskaja 1987 of Vaccinio-Fagion orientalis union (Zohary, 1973) Passarge 1981 of Rhododendro pontici-Fagetalia orientalis order (Soo, 1964) Pass. 1981, of Querco-Fagetea class Br.B1. et Vlieger 1937.

This research was conducted in the summer seasons of 2016 and 2019. The study involved geobotanical, population-ontogenetic, and soil-zoological methods.

\subsection{Geobotanical methods}

Square plots of $400 \mathrm{~m}^{2}$ were laid out for plant communities description. In each forest type there were made 37 geobotanical descriptions in the under-crown area, and 10 descriptions in the canopy gaps. 81 descriptions of under- crown areas and 30 descriptions of gaps were made in total. A complete floral list taking into account the layered structure of vegetation was made up for each plot. In each layer, the projective cover of species was defined according to the scale of J. Braun-Blanquet (1964, cited by Mirkin et al., 1989). Latin names of vascular plants and mosses are given according to World Flora Online (2020). Species diversity of communities was evaluated through the indicators of species richness and species saturation (Smirnova et al., 2002).

\subsection{Population-ontogenetic methods and classification of the ecological-coenotic groups of vascular plant}

The periodization of ontogenesis proposed by T.A. Rabotnov (1950) and supplemented by Uranov (1975) and his students (Zaugolnova et al., 1988) is used. The following states are distinguished in the tree ontogenesis: juvenile (j); immature (im); virginal (v); young generative (g1), mature generative (g2) and old generative (g3); senile (s) (Smirnova et. al., 1999; Evstigneev \& Korotkov, 2016). The ontogenetic states of woody plants were determined based on previously published works (Romanovsky, 2001; Evstigneev, 2014; etc.). The composition of tree cenopopulations was determined in under-crown areas and gaps in each forest type. Plots of different sizes were subjected to recording. Immature, virginal, generative and senile trees over $1.5 \mathrm{~m}$ high were counted on 0.25 ha plots (in triplicate for each forest type). Immature and virginal trees up to $1.5 \mathrm{~m}$ high were counted on $100 \mathrm{~m}^{2}$ plots (in 6-fold repetition for each forest type). Juvenile individuals were counted on $1 \mathrm{~m}^{2}$ plots (in 30 -fold repetition for each forest type). The data obtained were extrapolated for 1 ha. The type of ontogenetic spectrum was established according to the classification proposed by T.A. Rabotnov (1950), later supplemented and detailed (Rysin \& Rysina, 1966; Uranov \& Smirnova, 1969; Zaugolnova et al., 1988). In addition to ontogenetic states, the absolute age of trees was determined: core samples were taken with an increment borer near the base of the trunk to calculate the number of annual rings.

The paper is using the classification of the ecologicalcoenotic groups of vascular plant species developed for European Russia (Smirnova et al., 2002, 2004; Smirnova, 2004). The ecological-coenotic structure refers to the composition and quantitative ratio of species belonging to different ecological-coenotic groups. According to Nitcenko (1969) ecological-coenotic groups shall mean the large groups of ecologically close species that are associated with different types of communities in their genesis. All species were divided into the following ecological-coenotic groups: $\mathrm{Br}$ - boreal species, $\mathrm{Md}$ - meadow-forest edge, $\mathrm{Nm}$ - nemoral, $\mathrm{Nt}$ - nitrophilic, $\mathrm{Wt}$ - near-water, others other ECGs (Smirnova et al., 2017). 


\subsection{Soil-zoological methods}

Quantitative calculations of soil invertebrates of the macrofauna size bracket were carried out in gaps and undercrown areas of three forest types. Records in litter and soil were made by excavation and manual analysis of soil samples (Gilyarov, 1975). Invertebrates were fixed in 70$80 \%$ ethanol. The size of a separate sample was $25 \times 25$ $\mathrm{cm}$, the depth up to $30 \mathrm{~cm}$. In aspen-hornbeam forest 54 soil samples were taken in under-crown areas $(18-$ under aspen canopy and 18 - under hornbeam canopy) and 18 samples in the canopy gaps ( 3 gaps examined); in the beech-fir-hornbeam forest 72 soil samples were taken in under-crown areas (18 - under beech canopy, 18 - under fir canopy and 18 - under hornbeam canopy) and 18 samples in the canopy gaps ( 3 gaps examined); in the firbeech forest 54 soil samples were taken in under-crown areas (18 - under fir canopy and 18 under beech canopy) and 18 samples in the canopy gaps (3 gaps examined). Insects, mollusks, crustaceans, and millipedes were identified up to supraspecific taxa (using field guides (Likharev \& Rammelmeyer, 1952; Lokshina, 1969; Mamaev, 1972). Earthworm species were identified with field guides (Vsevolodova-Perel, 1997). The morphoecological groups of earthworms are differ in habitat in different soil horizons and in their functional role in the mineralization of organic residues (Bouche, 1977).

\subsection{Ecological characteristics of forest communities}

Ecological characteristics of communities ( $\mathrm{L}$ - light factor; $\mathrm{R}-\mathrm{pH} ; \mathrm{F}$ - soil moisture; $\mathrm{N}$ - nitrogen content; $\mathrm{T}$ thermal factor; $\mathrm{K}$ - continentality; $\mathrm{H}$ - soil humus) were obtained as weighted average scores for the corresponding species characteristics according to the ecological scale of Landolt (1977). Descriptions were ordinated with the indirect gradient detrended correspondence analysis and determination of the correlation level (r) and significance level (p) (Detrended Correspondence Analysis (DCA) in PC-ORD 5.0, SpeDiv, Past software).

\section{Results}

\subsection{The aspen-hornbeam forest type}

In the under-crown area, the tree stand is dominated by Carpinus betulus and codominated by Populus tremula. Cerasus avium, Fagus orientalis, and Quercus hartwissiana are found as admixture. Canopy closure is $80-90 \%$. Abies nordmanniana, Carpinus betulus, Corylus avellana, and Fagus orientalis are often found in the undergrowth layer, while Betula pubescens, Crataegus monogyna, and Daphne caucasica are found in the admixture together with
Pyrus caucasica and Quercus hartwissiana. The projective cover of the layer is $10-30 \%$. Lonicera caprifolium and Polygonatum glaberrimum dominate the herb-dwarf shrub layer, and Abies nordmanniana, Carex sylvatica, Carpinus betulus, Cerasus avium, Fraxinus excelsior, Hedera helix, Vincetoxicum scandens, etc. are common. The projective cover of the layer ranges from 30 to $70 \%$. The moss layer is distributed sporadically on elevations near the tree trunk and deadwood and is rarely seen on soil mounds; the projective cover is $3-5(10) \%$. Anomodon attenuatus, Brachytheciastrum velutinum, Hypnum cupressiforme, Leucodon sciuroides are the common species in the layer.

Light demanding species dominate the tree stand of the community. Shade-tolerant Abies nordmanniana and $\mathrm{Fa}$ gus orientalis are found as isolated rare trees. The full ontogenetic spectrum (with all ontogenetic groups represented in the ontogenetic spectrum of the species cenopopulation) was recorded for Carpinus betulus cenopopulation. In the aspen-hornbeam forest type, the first generation of hornbeam trees is decaying, and the share of standing dead trees reaches $40 \%$. The invasive type of the ontogenetic spectrum (with only juvenile and immature individuals represented in the spectrum) is typical for the cenopopulations of Acer platanoides, A. campestre, Fagus orientalis, and Fraxinus excelsior. Abies nordmanniana, Populus tremula, Quercus hartwissiana, and Tilia begoniifolia cenopopulations have the intermittent spectrum (with one or more ontogenetic groups missing from the spectrum), whereas Betula pubescens and Cerasus avium (Fig. 3) have fragmented spectrum (with only one or more ontogenetic groups present in the spectrum).

Soil macrofauna in the aspen-hornbeam type of forest in under-crown areas is represented by 19 orders and families. The total number of invertebrates is $127 \mathrm{ind} . / \mathrm{m}^{2}$, and the biomass is $6.27 \mathrm{~g} / \mathrm{m}^{2}$ (Table 1,2). Among trophic groups, saprophages and predators dominate in terms of quantity (Fig. 4), and saprophages in biomass (Table 2). Saprophages make up $83 \%$ of the total macrofauna biomass. The average number of litter and soil forms does not differ significantly (Fig. 5).

Differential consideration of under-crown areas shows that the density of macrofauna is twice as high under aspen crowns $\left(86 \pm 9.8\right.$ ind. $\left./ \mathrm{m}^{2}\right)$ as under hornbeam $(41 \pm 5.5$ ind./ $\mathrm{m}^{2}$ ), while the biomass between the two tree species does not differ $\left(3.17 \pm 1.7\right.$ and $3.10 \pm 2.5 \mathrm{~g} / \mathrm{m}^{2}$ under aspen and hornbeam crowns, respectively) due to the fact that by the summer season, easily decomposable hornbeam litter fall is mostly utilized whereas decomposition-resistant aspen litter fall still remains. Therefore, the number of small litter forms is higher in under-crown areas of aspen than in that of hornbeam. In under-crown areas of aspen the litter horizon is inhabited by representatives of fam. Elateridae, order Lithobiomorpha fam. Pholcidae, fam. Scarabaeidae, fam. Julidae, suborder Oniscidea, the mineral horizon is 


Table 1. The number of macrofauna (ind. $\left./ \mathrm{m}^{2}\right)$ in under-crown areas and canopy gaps

\begin{tabular}{|c|c|c|c|c|c|c|c|}
\hline \multirow{3}{*}{$\begin{array}{l}\text { Taxonomic groups of } \\
\text { invertebrates }\end{array}$} & \multirow{3}{*}{$\begin{array}{l}\text { Trophic } \\
\text { groups }\end{array}$} & \multicolumn{6}{|c|}{ Type of forest } \\
\hline & & \multicolumn{2}{|c|}{ aspen-hornbeam } & \multicolumn{2}{|c|}{ beech-fir-hornbeam } & \multicolumn{2}{|c|}{ fir-beech } \\
\hline & & $\begin{array}{l}\text { under- } \\
\text { crown }\end{array}$ & $\begin{array}{l}\text { canopy } \\
\text { gap }\end{array}$ & $\begin{array}{l}\text { under- } \\
\text { crown }\end{array}$ & $\begin{array}{l}\text { canopy } \\
\text { gap }\end{array}$ & $\begin{array}{l}\text { under- } \\
\text { crown }\end{array}$ & $\begin{array}{c}\text { canopy } \\
\text { gap }\end{array}$ \\
\hline fam. Araneidae & \multirow{10}{*}{ predators } & 0 & 0 & $2 \pm 0.1$ & 0 & 0 & 0 \\
\hline fam. Pholcidae & & $2 \pm 0.1^{*}$ & 0 & $6 \pm 2.3$ & 0 & 0 & 0 \\
\hline order Pseudoscorpionida & & $4 \pm 0.2$ & $4 \pm 2.5$ & $9.6 \pm 3.5$ & 0 & 0 & 0 \\
\hline order Scolopendrida & & $10 \pm 4.5$ & 0 & $1.8 \pm 0.3$ & 0 & $2 \pm 0.1$ & 0 \\
\hline order Geophilomorpha & & $12 \pm 4,5$ & $10 \pm 3.1$ & $9.6 \pm 3.2$ & $14 \pm 4.3$ & $8 \pm 0.8$ & $2 \pm 0.1$ \\
\hline order Lithobiomorpha & & $14 \pm 6.5$ & $14 \pm 6.2$ & $16.8 \pm 3.6$ & $14 \pm 2.4$ & $10 \pm 2.5$ & $10 \pm 1.5$ \\
\hline order Hemiptera & & 0 & 0 & $1 \pm 0.2$ & 0 & 0 & 0 \\
\hline fam. Carabidae & & $1 \pm 0.2$ & $8 \pm 4.5$ & $0.6 \pm 0.1$ & $4 \pm 0.2$ & $1 \pm 0.2$ & $4 \pm 0.4$ \\
\hline fam. Staphylinidae & & $2 \pm 0.1$ & $6 \pm 3.1$ & $3.6 \pm 0.4$ & $2 \pm 0.6$ & 0 & $4 \pm 0.4$ \\
\hline fam. Tenebrionidae & & 0 & $1 \pm 0.2$ & $1.2 \pm 0.2$ & $\mathbf{0}$ & 0 & $2 \pm 0.1$ \\
\hline fam. Chrysomelidae & \multirow{3}{*}{ phytophages } & $1 \pm 0.2$ & $4 \pm 2.4$ & $1.8 \pm 0.2$ & $2 \pm 0.1$ & 0 & 0 \\
\hline fam. Elateridae & & $11 \pm 4.6$ & $18 \pm 6.4$ & $13.2 \pm 4.5$ & $8 \pm 3.5$ & $7 \pm 2.2$ & $4 \pm 2.2$ \\
\hline fam. Scarabaeidae & & $6 \pm 4.3$ & $2 \pm 0.1$ & $1.8 \pm 0.3$ & $2 \pm 0.1$ & $1 \pm 0.2$ & $2 \pm 0.1$ \\
\hline superfam.Cucujoidea & \multirow{3}{*}{ mixophages } & 0 & 0 & 0 & 0 & $1 \pm 0.2$ & 0 \\
\hline fam. Forficulidae & & $5 \pm 2.5$ & $2 \pm 0.1$ & $1.8 \pm 0.2$ & $2 \pm 0.1$ & $1 \pm 0.2$ & $2 \pm 0.1$ \\
\hline order Trichoptera & & 0 & 0 & 0 & 0 & 0 & $2 \pm 0.1$ \\
\hline order Pulmonata & \multirow{9}{*}{ saprophages } & 0 & 0 & 0 & 0 & $1 \pm 0.2$ & 0 \\
\hline fam. Limacidae & & $3 \pm 0.5$ & $2 \pm 0.1$ & $3.6 \pm 0.3$ & $2 \pm 0.1$ & $3 \pm 0.1$ & $2 \pm 0.1$ \\
\hline fam. Lumbricidae & & $18 \pm 4.9$ & $66 \pm 9.5$ & $15 \pm 3.5$ & $44 \pm 3.6$ & $27 \pm 3.5$ & $42 \pm 2.5$ \\
\hline suborder Oniscidea & & $14 \pm 6.5$ & $18 \pm 6.3$ & $15 \pm 4.6$ & $18 \pm 4.5$ & $3 \pm 0.2$ & $2 \pm 0.1$ \\
\hline order Polydesmida & & 0 & 0 & $2 \pm 0.2$ & 0 & $2 \pm 0.1$ & 0 \\
\hline fam. Julidae & & $18 \pm 8.8$ & $26 \pm 4.8$ & $33.6 \pm 5.4$ & $16 \pm 2.8$ & $3 \pm 0.3$ & $2 \pm 0.1$ \\
\hline fam. Ectobiidae (imago) & & $1 \pm 0.2$ & 0 & 0 & 0 & 0 & 0 \\
\hline order Diptera (larvae) & & $1 \pm 0.2$ & $2 \pm 0.1$ & $3.6 \pm 0.4$ & $4 \pm 0.2$ & $3 \pm 0.3$ & 0 \\
\hline fam. Tipulidae (larvae) & & 0 & $4 \pm 0.8$ & 0 & $2 \pm 0.1$ & 0 & 0 \\
\hline fam. Lampyridae (imago) & \multirow{2}{*}{ afagi } & $2 \pm 0.1$ & 0 & $1 \pm 0.2$ & 0 & 0 & $2 \pm 0.1$ \\
\hline order Lepidoptera (cocoons) & & $2 \pm 0.1$ & 0 & 0 & 0 & 0 & 0 \\
\hline \multicolumn{2}{|l|}{ Total number: } & $127 \pm 15.6$ & $193 \pm 22.5$ & $144.6 \pm 31.2$ & $134 \pm 18.6$ & $76 \pm 15.4$ & $80 \pm 19.2$ \\
\hline
\end{tabular}

* bold type points out statistically significant differences between under-crown areas and canopy gaps within a single forest type (Kruskell-Wallis test)

dominated by representatives of the orders Scolopendrida, Geophilomorpha, fam. Lumbricidae and larvae of fam. Elateridae, among the representatives of fam. Lumbricidae only two species of the endogeic group of earthworms were found in the aspen under-crown areas: Aporrectodea jassyensis and Dendrobaena schmidti. In the undercrown areas of hornbeam the litter is inhabited by species of fam. Julidae, larvae of fam. Scarabaeidae and epigeic earthworms (fam. Lumbricidae). Three species of epigeic earthworms - Dendrobaena octaedra, Dendrodrilus rubi- dus tenuis, and Eiseniella tetraedra - were found. In the mineral horizon, representatives of the orders Scolopendrida, Lithobiomorpha, Geophilomorpha and endogeic worms A. jassyensis and D. schmidti are typical.

The canopy gap area in the aspen-hornbeam forest ranges from 290 to $365 \mathrm{~m}^{2}$, each gap is $10-15$ years old. On the periphery of the gaps, Carpinus betulus dominates the stand, Populus tremula is often the codominant; Alnus glutinosa, Fraxinus excelsior, Quercus hartwissiana, Betula pubescens, etc. are rarely found as admixture. The 
Table 2. Biomass of the main trophic groups of macrofauna $\left(\mathrm{g} / \mathrm{m}^{2}\right)$ in under-crown areas and canopy gaps

\begin{tabular}{|l|c|c|c|c|c|c|}
\hline \multirow{2}{*}{ Trophic groups } & \multicolumn{4}{|c|}{ Type of forest } \\
\cline { 2 - 8 } & \multicolumn{2}{|c|}{ aspen-hornbeam } & beech-fir-hornbeam & \multicolumn{3}{c|}{ fir-beech } \\
\cline { 2 - 8 } & under-crown & canopy gap & under-crown & canopy gap & under-crown & canopy gap \\
\hline saprophages & $5.2 \pm 1.4$ & $\mathbf{8 . 8} \pm \mathbf{2 . 2 *}$ & $5.03 \pm 1.2$ & $\mathbf{9 . 6} \pm \mathbf{2 . 4}$ & $9.7 \pm 4.4$ & $\mathbf{2 4 . 5} \pm \mathbf{4 . 8}$ \\
\hline predators & $0.56 \pm 0.05$ & $0.48 \pm 0.1$ & $0.61 \pm 0.3$ & $0.8 \pm 0.5$ & $0.44 \pm 012$ & $0.16 \pm 0.05$ \\
\hline phytophages & $0.37 \pm 0.1$ & $0.3 \pm 0.1$ & $0.34 \pm 01$ & $\mathbf{2 . 0 4} \pm \mathbf{0 . 9}$ & $0.08 \pm 0.06$ & $0.02 \pm 0.01$ \\
\hline mixophages & $0.14 \pm 0.1$ & $0.08 \pm 0.04$ & $0.02 \pm 0.01$ & $0.16 \pm 0.03$ & $0.08 \pm 0.3$ & $0.12 \pm 0.08$ \\
\hline Total biomass: & $6.27 \pm 2.4$ & $9.67 \pm 2.8$ & $6.0 \pm 1.5$ & $\mathbf{1 2 . 6} \pm \mathbf{3 . 7}$ & $10.3 \pm 2.5$ & $\mathbf{2 4 . 8} \pm \mathbf{3 . 8}$ \\
\hline
\end{tabular}

* bold type points statistically significant differences between under-crown areas and canopy gaps within a single forest type (Kruskell-Wallis test).

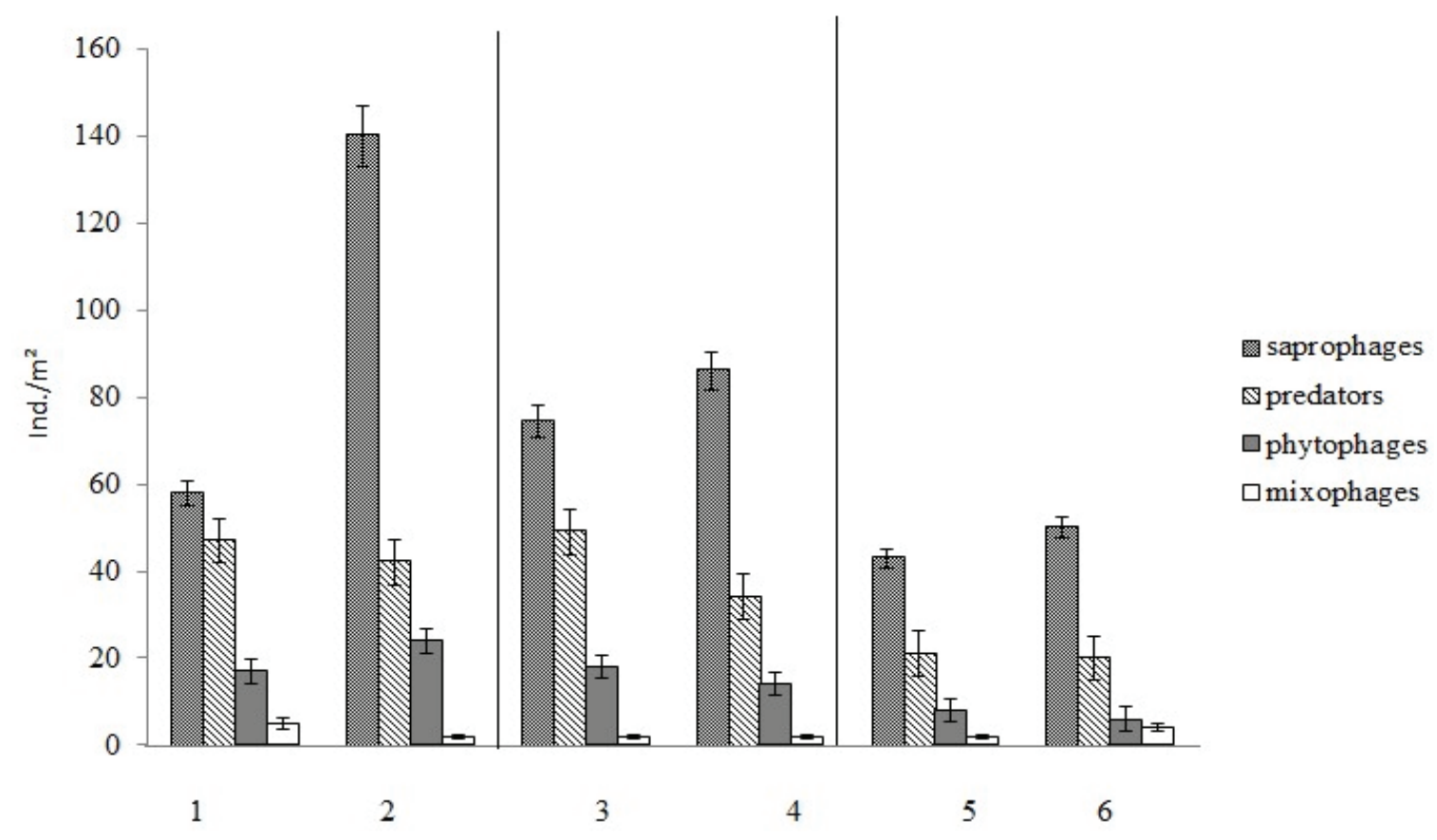

Figure 4. The number of trophic groups of soil macrofauna in under-crown areas $(1,3,5)$ and canopy gaps $(2,4,6)$ of coniferousdeciduous forests of the northwestern Caucasus (1-6 plant community numbers as in Fig. 2)

projective cover of the tree stand layer ranges from 10 to $30 \%$. The undergrowth is well developed, the projective cover ranges from 30 to $80 \%$. The tree stand is dominated by Alnus glutinosa, Carpinus betulus, Corylus avellana, and Abies nordmanniana. The projective cover of the herbdwarf shrub layer ranges from 40 to $100 \%$. Most often, the layer is dominated by Rubus caesius, often the co-dominants are Galeopsis tetrahit, Lonicera caprifolium, Fragaria vesca, Carex sylvatica, Solidago virgaurea and Viola alba subsp. dehnhardtii. The moss layer is well developed and confined to deadwood, mounds, and elevations near tree trunks. The projective cover of the layer ranges from 5 to $40 \%$. Hypnum cupressiforme, Leucodon immersus are common species here.

In the gaps of the aspen-hornbeam type of forest, the full ontogenetic spectrum (due to generative trees along the gap periphery) was found for the cenopopulation of Abies nordmanniana, Alnus glutinosa, Carpinus betulus, C. orientalis, Cerasus avium, Fagus orientalis, Fraxinus excelsior, Populus tremula, Pyrus caucasica, and Quercus hartwissiana. The invasive type was found for Acer campestre, A. platanoides, Tilia begoniifolia and Ulmus glabra, 
the intermittent type - for Crataeus monogyna (Fig. 3). Thus, in the gaps of young post-logging forests, both light demanding and shade-tolerant tree species are being successfully regenerating.

Representatives of 16 taxonomic groups of macrofauna (orders and families) were found in the gaps of aspenhornbeam forests. The total number (Table 1) and biomass (Fig. 6) of gap macrofauna are significantly higher than that of under-crown areas. At the same time, the number (Fig. 4) and biomass (Table 2) of predators, phytophages and mixophages in under-crown areas and gaps do not differ. Significant differences were found for the trophic group of saprophages - their number is almost 3 times higher, and biomass is 1.7 times higher in gaps as compared to under-crown areas. Unlike the under-crown areas the biomass of soil-dwelling invertebrates (Fig. 7) is high in gaps, particularly due to the presence of large earthworms, including the anecic form. The litter horizon is dominated by saprophages of the fam. Julidae and suborder Oniscidea as well as epigeic earthworms $D$. attemsi and D. octaedra. Single representatives of other groups and families are found. In mineral horizons, predators of order Geophilomorpha; saprophages: Diptera larvae and earthworms - endogeic species $A$. jassyensis and D. schmidti as well as a large anecic species $D$. mariupoliensis are common.

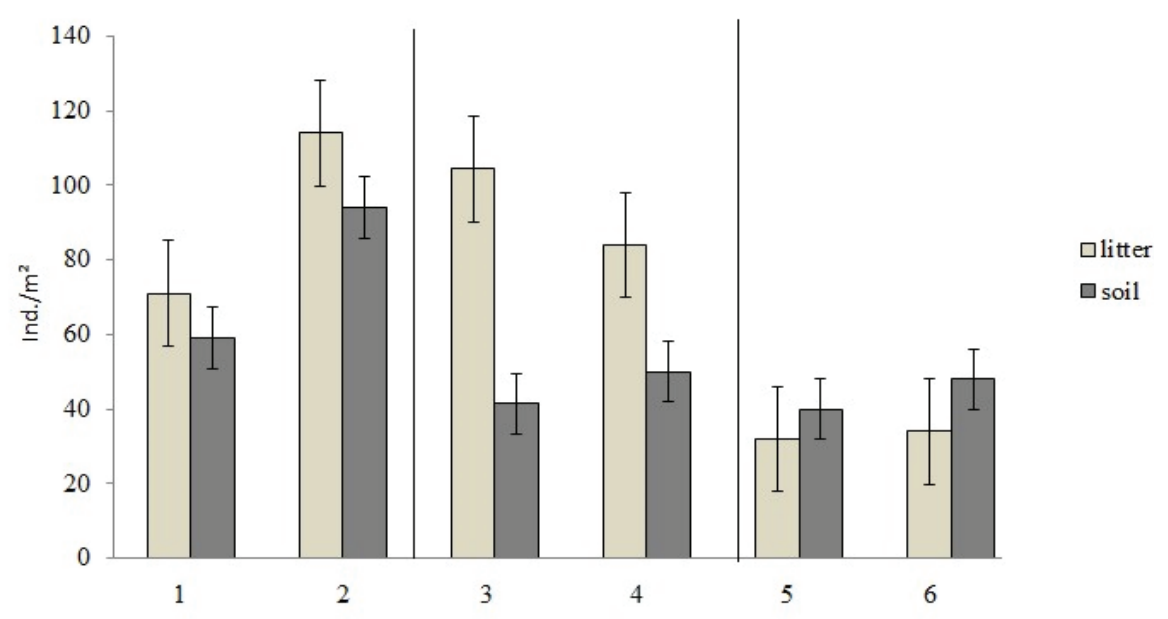

Figure 5. Average number of macrofauna in under-crown areas $(1,3,5)$ and canopy gaps $(2,4,6)$ of coniferous-deciduous forests of the northwestern Caucasus (1-6 plant community numbers as in Fig. 2)

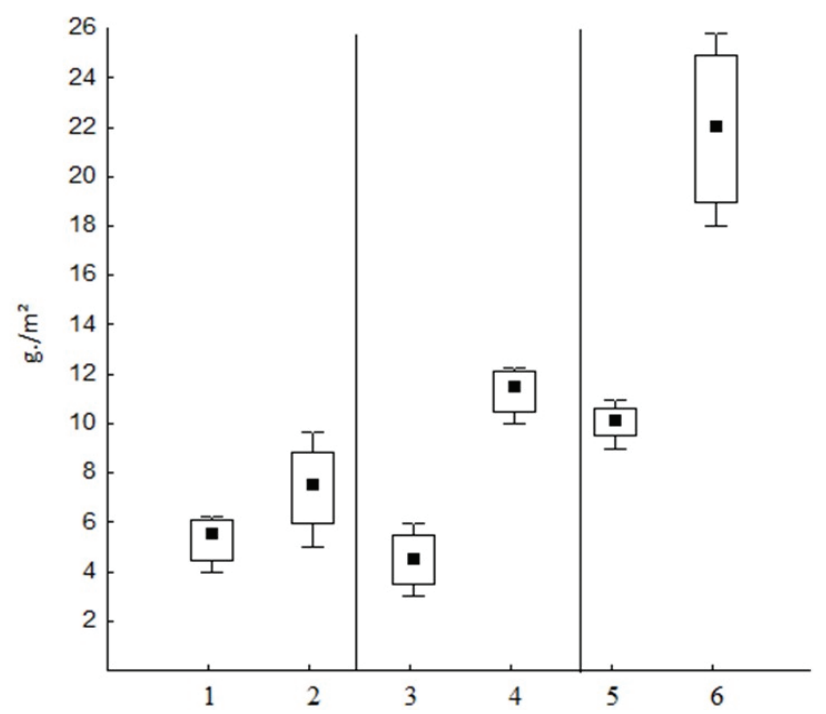

Figure 6. Total biomass of macrofauna in under-crown areas $(1,3,5)$ and canopy gaps $(2,4,6)$ of coniferous-deciduous forests of the northwestern Caucasus (1-6 plant community numbers as in Fig. 2) 




Figure 7. Average biomass of macrofauna in the soil and in the litter of under-crown areas $(1,3,5)$ and canopy gaps $(2,4,6)$ of coniferous-deciduous forests of the northwestern Caucasus (1-6 plant community numbers as in Fig. 2)

\subsection{Beech-fir-hornbeam type of forest}

In the under-crown area, the composition of the stand is codominated by Carpinus betulus, Fagus orientalis and Abies nordmanniana. Tilia begoniifolia is found in the admixture. The projective cover of the layer ranges from 70 to $90 \%$. The undergrowth is dominated by Abies nordmanniana (im, v) with the density 3-4, less frequently by Fagus orientalis - 1-2 and Rhododendron luteum (1). The projective cover of the layer ranges from 30 to $80 \%$. There are no dominants of the herb-dwarf shrub layer. Common species are Abies nordmanniana, Carex sylvatica, Dryopteris filix-mas, Euonymus europaea, Lonicera caprifolium, Polygonatum glaberrimum, Rubus caesius, Solidago virgaurea, Dioscorea communis; the projective coverage of the layer ranges from 20 to $60 \%$. The moss layer is localized on elevations near tree trunks, on tree trunks, deadwood, and stumps. Anomodon attenuatus, Hypnum cupressiforme, Leucodon sciuroides are common species.

In the under-crown areas of the fir-beech-hornbeam forest type, the full ontogenetic spectrum was observed for the cenopopulations of Abies nordmanniana and $\mathrm{Fa}$ gus orientalis. The intermittent spectrum was identified for the cenopopulations of Carpinus betulus, Fraxinus excelsior, Populus tremula, and Quercus petraea; invasive spectrum - for Acer platanoides, Cerasus avium, Tilia begoniifolia, and Crataegus monogyna. The fragmentary type of spectrum represented only by juvenile and immature individuals is typical for light demanding species, i.e. Betula pubescens, Castanea sativa, Pyrus caucasica, and Acer campestre (Fig. 3). Undergrowth of these species was found only in well-lit areas.
The soil macrofauna of the fir-beech-hornbeam type of forest includes representatives of 21 taxa (orders and families) totally amounting to $144 \mathrm{ind} . / \mathrm{m}^{2}$ in terms of numbers (Table 1) and to $6 \mathrm{~g} / \mathrm{m}^{2}$ in terms of biomass (Table 2) were identified in the under-crown areas. Saprophages clearly dominate among trophic groups both in number and in biomass, followed by predators, phytophages, and mixophages (Table 2), as in other types of forest. It is in this type of forest that differences between the number of litter and soil fauna are the greatest; litter is 2.7 times more densely inhabited than soil (Fig. 5) due to the fact that there is a thick mixed litter of decomposition-resistant fir and beech litter, while quickly decomposable hornbeam litter is a favourable trophic resource for litter fauna. Differential consideration of the distribution of invertebrates shows that the highest numbers and biomass of macrofauna were found under fir $\left(59 \pm 6.8\right.$ ind.$/ \mathrm{m}^{2}$ and $\left.2 \pm 0.6 \mathrm{~g} / \mathrm{m}^{2}\right)$ and hornbeam crowns $\left(51 \pm 7.2\right.$ ind.$/ \mathrm{m}^{2}$ and $\left.2.6 \pm 0.7 \mathrm{~g} / \mathrm{m}^{2}\right)$, whereas the lowest - under beech crowns $\left(34 \pm 6.5\right.$ ind.$/ \mathrm{m}^{2}$ and $\left.1.4 \pm 0.5 \mathrm{~g} / \mathrm{m}^{2}\right)$. In under-crown areas of fir, the litter is dominated by calciphilous groups: millipedes of fam. Julidae, order Polydesmida, woodlice (suborder Oniscidea). Geophila predators are typical (order Geophilomorpha) as well as drupes (order Lithobiomorpha) and saprophages earthworms, among which D. schmidti dominates are typical for humus and mineral horizons. The under-crown areas of hornbeam show the greatest variety of litter and soil macrofauna. Representatives of Lithobiomorpha, Pseudoscorpionida orders, and fam. Pholcidae and Staphylinidae as well as epigeic species of fam. Lumbricidae $D$. hortensis are typical for the litter. In the soil, the larvae of snapping beetles (fam. Elateridae) and dipterans (subor- 
der Diptera) are numerous, as well as predatory centipedes of Scolopendrida order and earthworms, among which $D$. schmidti dominates; also, a single anecic species $D$. mariupoliensis was found. Under the beech crowns, millipedes, woodlice and drupes dominate in the litter; in the soil, geophiles, larvae of snapping beetles, and earthworms are few in number - singular individuals of endogeic species D. schmidti and A. jassyensis are found in soil.

The area of canopy gaps ranges from 240 to $340 \mathrm{~m}^{2}$. The gaps are 10 to 15 years old. The stand of gaps peripheryis dominated by Carpinus betulus, Fagus orientalis, whereas Abies nordmanniana is found as admixture. Populus tremula, Quercus hartwissiana, Acer platanoides, and Alnus glutinosa are rare. The projective cover of the stand layer ranges from 10 to $30 \%$. The undergrowth is often dominated by Rhododendron luteum. Abies nordmanniana, Corylus avellana, Crataegus microphylla, etc are common species here. The projective cover of the layer varies greatly from 40 to $80 \%$. The herb-dwarf shrub layer is well developed, the projective cover is 60 to $100 \%$. The layer is dominated by Rubus caesius, Carex sylvatica, Dioscorea communis, Lonicera caprifolium, Rhododendron luteum, Galeopsis tetrahit, Lactuca muralis, Myosotis amoena, etc. Common moss species are Anomodon attenuatus, Atrichum undulatum, Leucodon sciuroides, Plagiomnium medium, etc. The projective cover of the moss layer varies from 3 to $25 \%$. Mosses are confined to dead wood, elevations near the tree trunk, mounds and stumps.

In the canopy gaps of the beech-fir-hornbeam forests, the full ontogenetic spectrum was observed for the cenopopulations of Abies nordmanniana, Acer campestre, A. laetum, Carpinus betulus, Cerasus avium, Crataegus monogyna, Fagus orientalis, Fraxinus excelsior, Pyrus caucasica, Quercus hartwissiana, and Tilia begoniifolia. The invasive type of spectrum was found for Alnus glutinosa, Castanea sativa, and Sorbus torminalis. The intermittent spectrum - for Acer platanoides and Populus tremula, fragmented - for Acer pseudoplatanus, Populus tremula and Ulmus glabra (Fig. 2). Thus, the beech-fir-hornbeam type of forest enjoys the regeneration of the largest number of tree species in comparison with other types of forest.

The macrofauna of the beech-fir-hornbeam forest gaps includes 14 taxa (orders and families), while the total number does not differ significantly from the number in the under-crown areas (Table 1), and the biomass is 2 times higher as compared to the under-crown areas (Table 2). The biomass of all trophic groups of invertebrates, i. e. saprophages, predators, phytophages, and mixophages is significantly higher in gaps (Table 2). The number of litter dwellers is higher than that of soil (Fig. 5), while the population of soil on the contrary exceeds that of litter in terms of biomass (Fig. 7). Saprophages such as woodlice, gastropods, millipedes, and epigeic earthworms are numerous in litter. Predators are less common and are mostly rep- resented by rove beetles and ground beetles. Among phytophages, imagines of leaf beetles and larvae of lamellicorn beetles are found. Soil is mostly inhabited by saprophages, among which earthworms are predominant: endogeic species D. schmidti and A. jassyensis and anecic species D. mariupoliensis are numerous. Millipedes, fly larvae, and larvae of crane flies (fam. Tipulidae) were also seen which were not found in under-crown areas.

\subsection{Fir-beech forest type}

In the under-crown areas, the stand is only codominated by Fagus orientalis and Abies nordmanniana. Acer platanoides and Carpinus betulus are found as admixtures. The upper sub-layer of the stand is represented exclusively by Fagus orientalis, while the lower one is represented by Abies nordmanniana with a small admixture of Fagus orientalis. The projective cover of the stand is $90-95 \%$. The undergrowth layer is dominated by Abies nordmanniana and Fagus orientalis. Ribes petraeum, Ilex colchica, and Rhododendron ponticum are found as singular trees. The projective cover of the layer ranges from 5 to $20 \%$. The herb-dwarf shrub layer is a dead-soil layer, the projective cover is $5-7 \%$. Common species are Abies nordmanniana, Acer platanoides, and Fagus orientalis. Singular plants of Cephalanthera rubra, Dryopteris filix-mas, Fraxinus excelsior, Moehringia trinervia, Monotropa hypopitys, Neottia nidus-avis and Tilia begoniifolia are found. The moss layer is localized on elevations near tree trunks, on tree trunks, deadwood, and soil. The projective cover is $5-10(12) \%$. Common species are Isothecium alopecuroides, Neckera complanata, Eurhynchium angustirete, Hypnum cupressiforme, Leucodon sciuroides and Ulota crispa.

Only the cenopopulation of Abies nordmanniana has the full ontogenetic spectrum in the under-crown area of the fir-beech forest. The cenopopulation of Fagus orientalis has an intermittent spectrum with no virginal individuals. The intermittent spectrum was also observed for the Carpinus betulus cenopopulation. Plants of this species with reduced vitality are found very rarely on the area of former gaps. Due to the high growth rate, hornbeam quickly occupies vacant areas. The invasive type is observed in Acer platanoides and Tilia begoniifolia, cenopopulations of Fraxinus excelsior, Betula pubescens, Cerasus avium, and Populus tremula have the fragmentary type of spectrum (Fig. 2). The undergrowth of the above species dies early due to the lack of light.

The composition of macrofauna in the fir-beech forest type is characterized by the smallest variety of taxonomic groups, and the smallest number (Table 1), but the biomass of macrofauna in this forest type is significantly higher than in other forest types (Fig. 6; Table 2). Representatives of 15 families and orders were found in the under-crown areas (Table 1). Among trophic groups, sap- 
rophages predominate (Fig. 4; Table 2), which account for more than half of the total population, and their biomass is $94 \%$ of the total biomass. The number and biomass of inhabitants of soil horizons is higher than that of the litter horizon (Fig. 5). The number and biomass of invertebrates in the under-crown areas of fir is significantly higher $\left(44 \pm 8.2\right.$ ind.$\left./ \mathrm{m}^{2} ; 5.9 \pm 1.5 \mathrm{~g} / \mathrm{m}^{2}\right)$ than under beech crowns ( $32 \pm 8.8$ ind. $\mathrm{m}^{2}$ and $4.6 \pm 1.4 \mathrm{~g} / \mathrm{m}^{2}$ ). Larvae and imagines of snapping beetles, millipedes, woodlice, and earwigs are typical inhabitants of fir under-crown areas in litter (fam. Forficulidae); in soil there are predatory millipedes (order Scolopendrida, Lithobiomorpha, Geophilomorpha) and earthworms (D. schmidti and D. mariupoliensis). In the under-crown areas of beech, imagines of snapping beetles (Agriotes sputator) and drupes (Lithobiomorpha) are numerous in litter, whereas earthworms (D. schmidti and D. mariupoliensis) are found in soil.

Canopy gaps are formed as a result of the natural death of old Fagus orientalis trees in the upper sub-layer (trees 40-60 meters high). $80 \%$ of gaps in the fir-beech type of forest were formed as a result of breakage of old beech trees trunks at a height of more than 1 meter, rather than of treefall. During the fall of old trees of the upper sublayer, Fagus orientalis and Abies nordmanniana trees of the lower sub-layer are usually the ones that tend to break. The size of gaps in old-aged fir-beech forests ranges from 320 to $380 \mathrm{~m}^{2}$. Gaps are 10 to 20 years old.

Abies nordmanniana and Fagus orientalis codominate along the periphery of gaps in the tree stand. Earlygenerative Carpinus betulus and Fraxinus excelsior trees are rarely found as admixture. The projective cover of the layer is $5-15 \%$. The undergrowth is dominated by young Fagus orientalis and Abies nordmanniana. The admixture contains Carpinus betulus, Cerasus avium, Sambucus herbacea, S. nigra, Tilia begoniifolia, Fraxinus excelsior and Philadelphus copronarius. The projective cover of the layer is $30-60 \%$. The herb-dwarf shrub layer is unevenly developed, the projective cover ranges from 20 to $100 \%$. Abies nordmanniana, Acer platanoides, Athyrium filix-femina, Carpinus betulus, Circaea lutetiana, Dryopteris filix-mas, Fagus orientalis, Fragaria vesca, Fraxinus excelsior, Prunus laurocerasus, Rubus caesius, Tilia begoniifolia, and Viola mirabilis are common. Rubus caesius and the undergrowth of Abies nordmanniana, Acer platanoides, Carpinus betulus, Fagus orientalis etc. often dominate. Moss is developed sporadically on elevations near tree trunks, on deadwood and mounds. Brachythecium rutabulum, Eurhynchium angustirete, Hypnum cupressiforme, Isothecium alopecuroides, Leucodon sciuroides, Neckera complanata, Pterigynandrum filiforme, Ulota crispa are common.

Cenopopulations of Abies nordmanniana, Acer campester, Carpinus betulus, Fagus orientalis, Fraxinus excelsior, and Tilia begoniifolia have the full ontogenetic spectrum in the gaps of fir-beech forest. The invasive type of spectrum was described for Acer pseudoplatanus, Quercus hartwissiana, Prunus laurocerasus, and Salix caprea; the intermittent type - for Acer platanoides, Cerasus avium and fragmented - for Populus tremula (Fig. 2). Thus, at a late stage, successful restoration of gaps is due to shadetolerant tree species.

The macrofauna in the gaps of the beech-fir type includes 14 taxa (orders and families). The total number does not differ significantly from the under-crown areas (Table 1), but the biomass is 2.5 times higher in comparison with the under-crown areas due to the biomass of soil saprophages (Table 2). Invertebrate biomass in soil is 20 times higher than in litter (Fig. 7), which is due to the high density of earthworms of not only endogeic forms (D. schmidti) but also of large anecic earthworms (D. mariupoliensis). The density of predators, phytophages and mixophages is low (Table 2). The most common soil predators are drupes (order Lithobiomorpha), other representatives are few. It is however interesting that water-loving invertebrates: not only earthworms, mollusks, larvae of dipterans, but also larvae of caddisflies (order Trichoptera) inhabit this area, which serves as an indicator of high soil moisture in the studied forest gaps.

\section{Discussion}

In the studied types of coniferous-deciduous forests of the northwestern Caucasus, the regeneration of tree cenopopulations is much more effective in gaps as compared to under-crown areas. In aspen-hornbeam forests, in undercrown areas the regeneration of 11 tree species was recorded, of which cenopopulations of only 2 species had full ontogenetic spectra with a steady cycle of generations, in the gaps there were 15 species, of which 10 species had full ontogenetic spectra; in the beech-fir-hornbeam forests, in under-crown areas the regeneration of 14 tree species was recorded, with the full ontogenetic spectrum of cenopopulations of only two species, whereas in gaps there were 18 tree species, of which 11 tree species had full ontogenetic spectrum; in old-aged fir-beech forests, in under-crown areas the regeneration of 9 tree species was recorded, of which only cenopopulations of Abies nordmanniana had a steady cycle of generations, in the gaps there were 12 species, with the full ontogenetic spectrum of the populations of 6 tree species (Fig. 2). It is important to note that in all the studied types of coniferous-deciduous forests of the northwestern Caucasus, gaps are not only the place of successful regeneration of a much larger number of tree species cenopopulations, but also the density of tree undergrowth of different species in the gaps is more than 10 times higher than in under-crown areas. The significant role of gaps in the successful regeneration of tree species was noted in oak-pine forests in the United States (Schu- 
mann et al., 2003), beech-dominated forests in Denmark (Ritter et al., 2005), beech forests of Iran (Haghverdi et al., 2012), tropical forests of Costa Rica, where experimental felling with the creation of gaps resulted in successful development of undergrowth, especially that of light demanding species (Dupuy \& Chardon, 2008).

As can be seen from the graph (Fig. 8), the highest species density of vascular plants (the number of species per $400 \mathrm{~m}^{2}$ ) in the under-crown areas of the studied forest types is found for the aspen-hornbeam and beech-fir-hornbeam forest, the lowest - for old-aged fir-beech forests. Low species density of the latter is due to high closure of the tree canopy and, as a result, almost complete absence of ground cover. In the fir-beech type of forest, the height of the tree canopy reaches $60 \mathrm{~m}$. The tree stand is represented by two distinct sub-layers: the lower one is $20-30 \mathrm{~m}$ and the upper one is 50-60 m high. The upper sub-layer is formed by Fagus orientalis, and the lower one - by Abies nordmanniana, which leads to strong shading and the formation of dead-soil communities. In the aspen-hornbeam and beech-fir-hornbeam types of forest, due to the decay of the first generation of tree species, the community is well lit, so there are more favourable conditions for the settlement of light demanding flora of vascular plants, mosses and liverworts.

In the gaps of all types of forest, species density is almost two or more times higher than in under-crown communities, which is explained by good light factor and high soil moisture, as the stand does not intercept precipitation.
These two factors are usually listed as determining a significant increase in the species richness of plants in gaps in comparison with under-crown areas (Denslow \& Spies, 1990). Previous studies showed conclusively that species density of plants is positively correlated with the size of the gap, which determines the amount of light in the first place (Schumann et al., 2003; Ritter et al., 2005; Haghverdi et al., 2012). Our research has shown that not only the size of the gap but also the height of the stand on the periphery of the gaps determines the species density of plants: in the gaps of old-aged fir-beech forests, species density is significantly lower as compared to the gaps of aspen-hornbeam and beech-fir-hornbeam forests due to the high height of the tree canopy (up to 50-60 m) along the periphery of the gaps in fir-beech forests, which creates strong lateral shading and diasporic isolation.

The diagram (Fig. 9) shows vectors of environmental factors whose length and direction reflect the degree of correlation of factors with axes but are not regression lines in the strict sense. The highest correlation with the first DCA axis $(\mathrm{p}<0.005)$ is shown by the indicators of light factor $(\mathrm{r}=-0.96)$, continentality $(\mathrm{r}=-0.87)$, soil humus content $(\mathrm{r}=0.64)$, soil $\mathrm{pH}(\mathrm{r}=-0.63)$, and thermal factor $(\mathrm{r}=-0.58)$. There is no significant strong correlation with the second axis. Only soil nitrogen content showed correlation with the third axis $(\mathrm{r}=0.55)$.

Results of the multi-dimensional analysis of geobotanical descriptions of communities of under-crown areas and gaps in dominant forest types on the ecological scale of



Figure 8. Plant species richness in under-crown areas $(1,3,5)$ and canopy gaps $(2,4,6)$ of coniferous-deciduous forests of the northwestern Caucasus (1-6 plant community numbers as in Fig. 2) 
Landolt (1977) clearly showed that aspen-hornbeam and beech-fir-hornbeam forests have the highest similarity in the under-crown area and gaps: they have a higher proportion of light demanding, heat-loving species that prefer a more neutral and nitrogen-rich soil compared to communities of fir-beech forests. At the same time, in the undercrown area and gaps of fir-beech forests, the share of light demanding species is low whereas the share of plant species that prefer soil with high humus and moisture content is higher, which is also noted for moisture-loving groups of invertebrates.

The ecological-coenotic structure of all dominant types of coniferous-deciduous forests of the northwestern Caucasus in under-crown area and gaps in terms of the number of species is clearly dominated by nemoral species (50 to $80 \%$ of all species), forming the core of the local flora. Boreal species (from 8 to $25 \%$ ) are in second place in terms of species number in the under-crown area, whereas in gaps it is the meadow-forest edge species (from 12 to 25\%) and nitrophilic species (from 5 to 11\%). The share of other groups is insignificant (Fig. 10).

It is important to note that only gap communities in all types of forest include the group of near-water plant spe- cies. This is due to the fact that the ground cover in the gaps receives more moisture from precipitation than that under the canopy, where precipitation is intercepted by tree crowns. In the gaps, large puddles are often formed and remain for a long time, leading to hydrogenic conditions. For example, in the composition of the flora in gaps, such near-water species as Alisma plantago-aquatica, Juncus effusus, Cardamine tenera, Galeopsis tetrahit, Ranunculus repens, etc. are common. And in the composition of the soil macrofauna, even larvae of caddisflies (order Trichoptera) are found.

Due to the fact that soil moisture supply is the most important factor for the functioning of soil invertebrates, especially water-loving saprophages, in the gaps of all types of forest, the saprophage biomass is significantly higher than in under-crown areas. This is most pronounced in oldaged fir-beech forests where much of the precipitation is intercepted by tree crowns. Studies of the influence of tree gaps on the distribution of earthworms in the beech forests of Iran (Kooch \& Hosseini, 2010; Kooch \& Haghverdi, 2014) show that the density and biomass of earthworms decreases as the gaps size increases, and often, the density of earthworms may be higher under the tree canopy, which

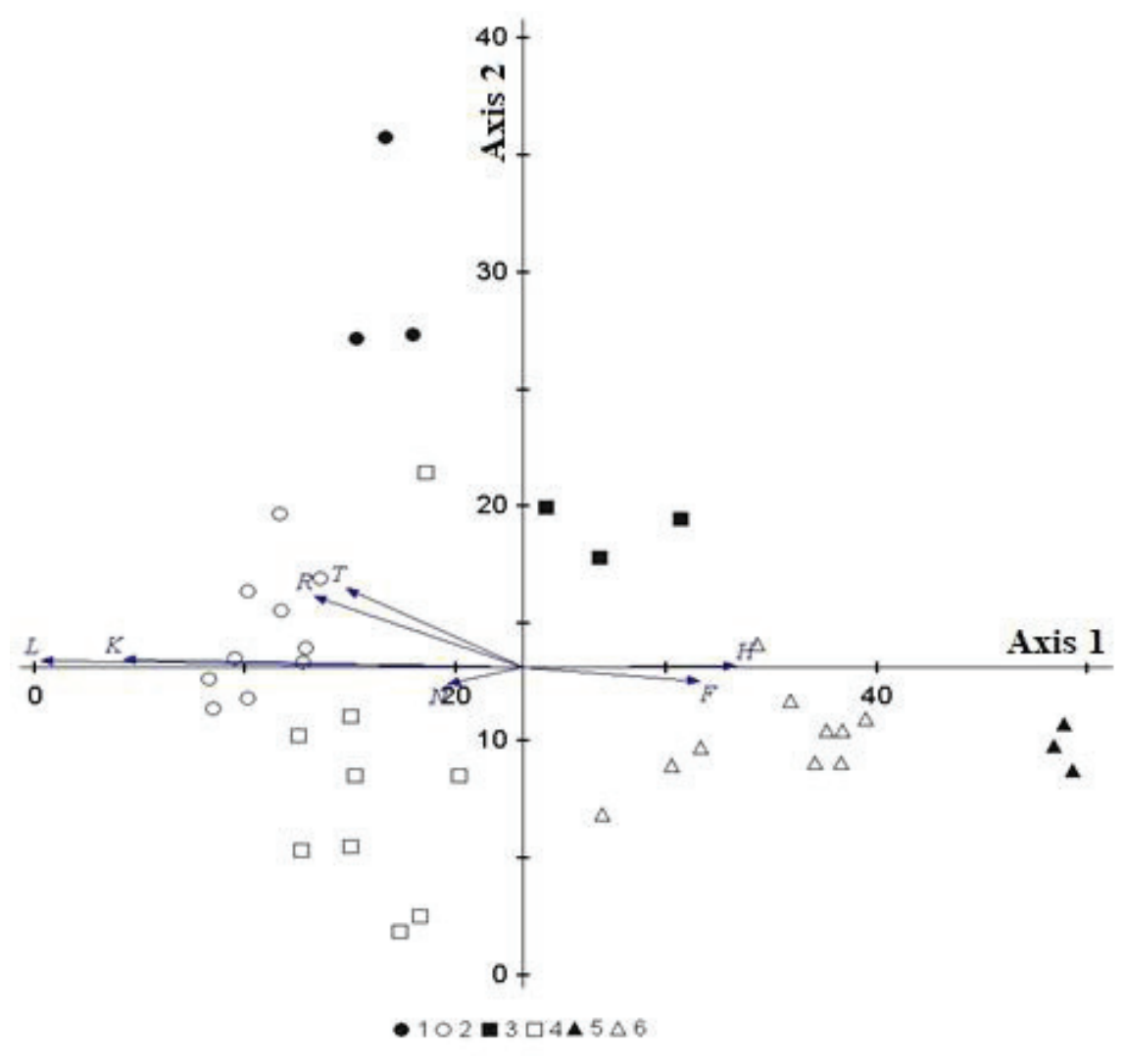

Figure 9. The position of the geobotanical descriptions of the studied communities in the first two axes of DCA together with the vectors of environmental factors (in ecological scale of Landolt (1977); 1-6 plant community numbers as in Fig. 2) 
is explain by the authors by faster drying of the soil in open spaces as compared to the closed ones. In our research, the opposite patterns were seen. This is most likely due to the fact that in the climate of Iran, most of the precipitation falls from September to November (Kooch \& Haghverdi, 2014), while the total amount of precipitation during the year is 1.7 times lower (720 $\mathrm{mm}$ annual rainfall) than in the forests under our research and, moreover, summers are often dry. In the forests of the northwestern Caucasus we studied, the maximum precipitation falls from May to July during the optimal temperature for the soil fauna activity; there are no sharp fluctuations between the seasons and the total amount of precipitation is at least $1.200 \mathrm{~mm}$ of annual rainfall. This uniform humidification creates more favourable conditions for moisture-loving groups of flora and fauna in the gaps as compared to closed under-crown areas.

In the under-crown area, the largest number of ecological-coenotic groups of plants (Fig. 10) was found in beechfir-hornbeam forests (all 6 selected groups). As mentioned above, in these forests, the first post-harvest generation of trees disintegrates and the ground cover lightens, accompanied by an increase in species richness. In the undercrown area of fir-beech forests, on the contrary, a marked decline in the number of ecological-coenotic groups (up to $2-$ nemoral and boreal species) is found that is connected with a strong shading of ground vegetation by trees canopy and formation of dead-soil oligodominant communities. It should be noted that the gaps of all dominant forest types have the maximum number of ecological-coenotic groups of plants (all 6 groups), which is an important feature of gap plant communities as compared to the communities of the under-crown area.

Taxonomic diversity of soil macrofauna in under-crown areas and floristic richness are highest in aspen-hornbeam and beech-fir-hornbeam forests and lowest in fir-beech forests. It is known that the more diverse is the forest stand composition, the higher is the taxonomic and functional diversity of the soil fauna (Cesarz et al., 2007; Sariyildiz \& Küçük, 2008). The composition of litter determines not only trophic conditions for invertebrates (high content of available nutrients, biogenic elements, low acidity, etc.), but also topical conditions: slowly decomposing litter serves as a favourable habitat for the litter fauna, therefore mixed litter of the litter fall of different quality in beechfir-hornbeam forests is more favourable for a larger number of invertebrates. However, in gaps, in contrast to the floristic diversity of all forest types, the taxonomic diversity of macrofauna is reduced; functional diversity, however, is preserved: all the main trophic groups of macrosaprophages are present in gaps, and gaps are an important

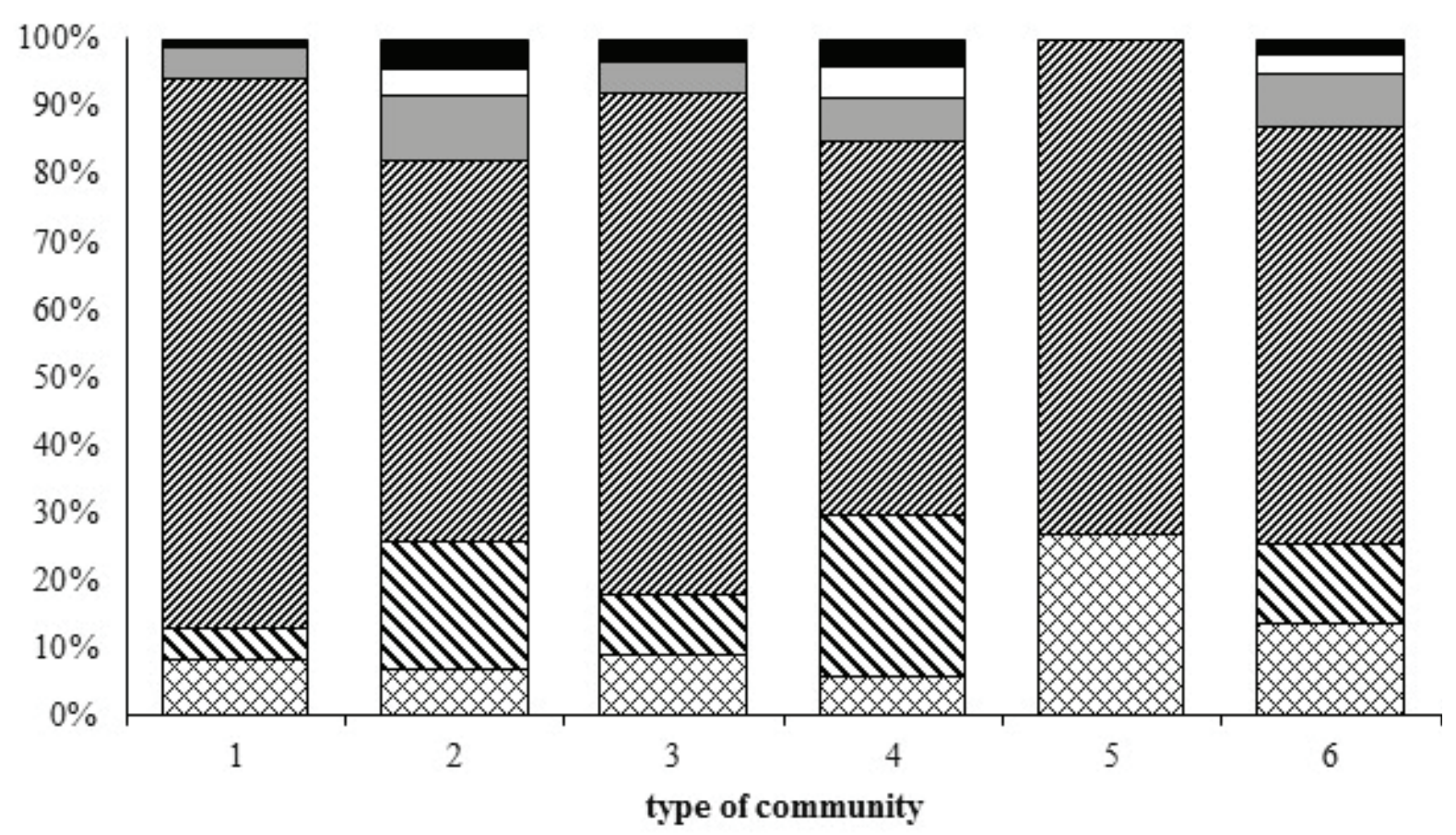

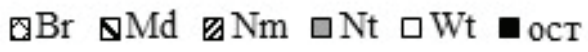

Figure 10. The ratio of eco-cenotic groups of plants of different forest types in under-crown areas $(1,3,5)$ and canopy gaps $(2,4,6)$. Note: 1-6 plant community numbers as in Fig. 2. 
element of the forest mosaic which are in the first place important for the functioning of large soil saprophages earthworms, which process the plant litter. Only gaps have a high biomass of anecic earthworms which are important ecosystem engineers (Lavelle et al., 1997; Eisenhauer et al., 2008; Kooch \& Jalilvand, 2008) and are rarely found in forest communities, being represented usually only in old-aged virgin forests (Geraskina, 2019).

\section{Conclusions}

Thus, it has been found that in the canopy gaps of the studied types of coniferous-deciduous forests of the northwestern Caucasus, the species density of plants is almost two or more times higher than that in the under-crown area due to good light factor and high soil moisture, since the stand does not intercept the rainfall. Regeneration of tree cenopopulations in all types of forest is much more effective in canopy gaps compared to under-crown areas. The density of undergrowth of different types of trees in the canopy gaps is more than 10 times higher than that in the under-crown areas. The maximum number of ecological-coenotic groups of plants is marked in the canopy gaps of all types of forest. All major trophic groups of macrofauna live in the canopy gaps as well as in under-crown areas, but their biomass in gaps is significantly higher than in under-crown areas. Due to the fact that soil moisture supply is also an important factor for the functioning of macrofauna, especially water-loving saprophages, the average saprophages biomass in gaps of all types of forest is 2 times higher than in under-crown areas. Only the gaps have a high biomass of anecic earthworms, which are rarely found in forest communities, and contribute greatly to the transformation of plant litter.

\section{Acknowledgement}

The scientific materials were collected by of state assignment "Methodical approaches to the assessment of the structural organization and functioning of forest ecosystems" No. AAAA-A18-1180052590019-7 and results of the study were processed by supported Russian Science Foundation (project 16-17-10284).

\section{References}

Bertemucci P., Coates K.G., Harper K.A. \& Wright E.F., 2002, Gap disturbances in northern old-growth forests of British Columbia, Canada. Journal of Vegetation Science 13(5): 685-696.

Bouche M.B., 1977, Strategies lombriciennes. Ecological Bulletins 25: 122-132.
Cesarz S., Fahrenholz N., Migge-Kleian S., Platner C. \& Schaefer M., 2007, Earthworm communities in relation to tree diversity in a deciduous forest. European Journal of Soil Biology 43(1): 61-67.

Denslow J.S. \& Spies T., 1990, Canopy gaps in forest ecosystems: an introduction. Canadian Journal of Forest Research 20(5): 619-619.

Dupuy J.M. \& Chazdon R.L., 2008, Interacting effects of canopy gap, understory vegetation and leaf litter on tree seedling recruitment and composition in tropical secondary forests. Forest Ecology and Management 255(11): 3716-3725.

Eisenhauer N., Milcu A., Sabais A.C. \& Scheu S., 2008, Animal ecosystem engineers modulate the diversityinvasibility relationship. PLoS One 3(10): e3489.

Evstigneev O.I., 2014, Polivariantnost' sosny obyknovennoj v Brjanskom Poles'e [Ontogenesis polyvariancy of Scotch Pine in Bryansk Polesia]. Russian Forest Science 2: 69-77.

Evstigneev O.I. \& Korotkov V.N., 2016, Pine Forest Succession on Sandy Ridges within Outwash Plain (Sandur) in Nerussa-Desna Polesie. Russian Journal of Ecosystem Ecology 1(3): 1-18.

Frouz J., Liveckova M., Albrechtova J., Chronakova A., Cajthaml T., Pizl V., Hanel L., Stary J., Baldrian P., Lhotakova Z., Simackova H. \& Cepakova S., 2013, Is the effect of trees on soil properties mediated by soil fauna? A case study from post-mining sites. Forest Ecology and Management 309: 87-95.

Gandolfi S., Joly C.A. \& Rodrigues R.R., 2007, Permeability-impermeability: canopy trees as biodiversity filters. Scientia Agricola 64(4): 433-438.

Geraskina A.P., 2019, Transformations of earthworm communities during post-logging successions in the forests of the Northwest Caucasus. Lesovedenie 2(2): $1-14$.

Geraskina A. \& Shevchenko N., 2019, Spatial distribution of the epigeic species of earthworms Dendrobaena octaedra and D. attemsi (Oligochaeta: Lumbricidae) in the forest belt of the northwestern Caucasus. Turkish Journal of Zoology 43(5): 480-489.

Gilyarov M.S., 1975, Metody pochvenno-zoologicheskih issledovanij [Methods of soil and zoological research]. Nauka, Moscow, 304 pp.

Gvozdetsky O.N., 1963, Kavkaz. Ocherki prirody [Caucasus. Essay on nature]. Geografgiz, Moscow, 264 pp.

Haghverdi K., Kiadaliri H., Sagheb-Talebi K.Y. \& Kooch Y., 2012, Variability of plant diversity and soil features following gap creation in Caspian Beech Forests of Iran. Annals of Biological Research 3(9): 4622-4635.

Ignatov M.S., Afonina O.M., Ignatova E.A., Abolina A., Akatova T.V., ... \& Zolotov V.I., 2006, The checklist of mosses of East Europe and North Asia. Arctoa 15: $1-130$. 
Kooch Y. \& Haghverdi K., 2014, Earthworms-good indicators for forest disturbance. Journal of BioScience and Biotechnology 3(2): 155-162.

Kooch Y. \& Hosseini S.M., 2010, Response of earthworms biomass and diversity to windthrow events and soil properties in Hyrcanian forests of Iran. Folia oecologica 37(2): 181-190.

Kooch Y. \& Jalilvand H., 2008, Earthworms as ecosystem engineers and the most important detritivors in forest soils. Pakistan Journal of Biological Sciences 11(6): 819-825.

Landolt E., 1977, Okologische Zeigerwerte zur Schweizer Flora [Ecological pointer values for Swiss flora]. Vol. 64. Veroff. Geobot. Inst. ETH, Zurich, 208 pp.

Lavelle P., Bignell D., Lepage M., Wolters V., Roger P.A., \& Dhillion S., 1997, Soil function in a changing world: the role of invertebrate ecosystem engineers. European Journal of Soil Biology 33(4): 159-193.

Likharev I.M. \& Rammelmeyer E.U., 1952, Nazemnye molljuski fauny SSSR [Ground mollusks of the fauna of the USSR]. AS USSR, Moscow-Leningrad, $511 \mathrm{pp}$.

Lokshina I.E., 1969, Opredelitel' dvuparnonogih mnogonozhek (Diplopoda) ravninnoj chasti Evropejskoj territorij SSSR [Key two-legged millipedes (Diplopoda) of the flat part of the European territory of the USSR]. Nauka, Moscow, 78 pp.

Lukina N.V., Tikhonova E.V., Shevchenko N.E., Gornov A.V., Kuznetsova A.I., ... \& Shanin V.N., 2018, Akkumuljacija ugleroda $\mathrm{v}$ lesnyh pochvah i sukcessionnyj status lesov [Carbon accumulation in forest soils and forest succession status]. KMK, Moscow, 232 pp.

Mamaev B.M., 1972, Opredelitel' nasekomyh po lichinkam: posobie dlja uchitelej [Identifier of insects on larvae: a manual for teachers]. Prosveshhenie, Moscow, 400 pp.

Milkov F.N. \& Gvozdetsky O.N., 1986, Fizicheskaja geografija SSSR. Obshhij obzor. Evropejskaja chast' SSSR. Kavkaz [Physical geography of the USSR. General review. The European part of the USSR. Caucasus]. Vysshaja shkola, Moscow, 376 pp.

Mirkin B.M., Rosenberg G.S. \& Naumova L.G., 1989 , Slovar' ponjatij i terminov sovremennoj fitocenologii [Dictionary of concepts and terms of modern phytocenology]. Nauka, Moscow, 223 pp.

Muscolo A., Bagnato S., Sidari M. \& Mercurio R., 2014, A review of the roles of forest canopy gaps. Journal of Forestry Research 25(4): 725-736.

Nitcenko A.A., 1969, Ob izuchenii jekologicheskoj struktury rastitel'nogo pokrova [On the study of the ecological structure of vegetation]. Botanical Journal 54(7): 1002-1014.

Oldeman R.A.A., 1983, Tropical rain forest: architecture, sylvigenesis and diversity. [in:] S.L. Sutton, T.C. Whitmore, A.C. Chadwick (eds), Tropical rain for- est: ecology and management. Blackwell, Oxford, pp. $139-150$

Orlova M.A., Lukina N.V., Smirnov V.E., Krasnov D.A. \& Kamaev I.O., 2012, Fertility of soils under spruce forests of the Khibiny Mountains. Eurasian soil science 45(6): 612-624.

Rabotnov T.A., 1950, Zhiznennyj cikl mnogoletnih travjanistyh rastenij $\mathrm{v}$ lugovyh cenozah [The life cycle of perennial herbaceous plants in meadow cenoses]. Trudy Botanicheskogo instituta AN SSSR, Series 3. Geobotany 6: 7-204.

Rebertus A.J. \& Veblen T.T., 1993, Structure and tree-fall gap dynamics of old-growth Notofagus forests in Tierra del Fuego, Argentina. Journal of Vegetation Science 4(5): 641-654.

Ritter E., Dalsgaard L. \& Einhorn K.S., 2005, Light, temperature and soil moisture regimes following gap formation in a semi-natural beech-dominated forest in Denmark. Forest Ecology and Management 206(1-3): 15-33.

Romanovsky A.M., 2001, Polivariantnost' ontogeneza Picea abies (Sosnovye) v Brjanskom lesu [Multivariance of the ontogenesis of Picea abies (Pinaceae) in Bryansk woodland]. Botanicheskij Zhurnal 86(8): 72-85.

Runkle J.R., 2000, Canopy tree turnover in old-growth mesic forests of eastern North America. Ecology 81(2): 554-567.

Rysin L.P. \& Rysina G.P., 1966, Opyt populjacionnogo analiza lesnyh soobshhestv [Experience in population analysis of forest communications]. Bulletin of the Moscow Society of Naturalists. Biological Department 21(1): 84-94.

Sariyildiz T. \& Küçük M., 2008, Litter mass loss rates in deciduous and coniferous trees in Artvin, northeast Turkey: Relationships with litter quality, microclimate, and soil characteristics. Turkish Journal of Agriculture and Forestry 32(6): 547-559.

Schumann M.E., White A.S. \& Witham J.W., 2003, The effects of harvest-created gaps on plant species diversity, composition, and abundance in a Maine oakpine forest. Forest ecology and management 176(1-3): 543-561.

Shishov L.L., Tonkonogov V.D., Lebedev A.I. \& Gerasimova M.I., 2004, Klassifikacija i diagnostika pochv Rossii [Classification and diagnostics of Russian soils]. Ojkumena, Smolensk, 342 pp.

Smirnova O.V., 2004, Prirodnaja organizacija biogeocenoticheskogo pokrova lesnogo pojasa Vostochnoj Evropy [The natural organization of the biogeocenotic cover of the forest belt of Eastern Europe], [in:] O.V. Smirnova (ed.), Eastern European forests: history in the Holocene and modernity. Book 1. Nauka, Moscow, p. 16-50.

Smirnova O.V., Chistyakova A.A., Zaugolnova L.B., Evstigneev O.I., Popadiouk R.V. \& Romanovsky A.M., 
1999, Ontogeny of a tree. Botanical Journal 84(12): 8-20.

Smirnova O.V., Khanina L.G. \& Smirnov V.E., 2004, Jekologo-cenoticheskie gruppy rastitel'nosti lesnogo pojasa Vostochnoj Evropy [Ecological and coenotic groups in the vegetation of the forest belt of Eastern Europe], [in:] O.V. Smirnova (ed.), Eastern European forests: history in the Holocene and modernity. Book 1. Nauka, Moscow, p. 165-175.

Smirnova O.V., Bobrovsky M.V., Khanina L.G., 2017, European Russian forests: Their current state and features of their history. Plant and Vegetation. Vol. 15. Springer, Dordrecht: 1-566.

Smirnova O.V., Zaugolgova L.B., Khanina L.G., Bobrovsky M.V. \& Toropova N.A., 2002, Populjacionnye i fitocenoticheskie metody analiza bioraznoobrazija rastitel'nogo pokrova [Population and phytocenotic methods for the analysis of biodiversity of the plant cover], [in:] Conservation and restoration of biodiversity. Izdatel'stvo Nauchno-obrazovatel'nogo centra, Moscow, pp. 145-194.

Uranov A.A., 1975, Vozrastnoj spektr fitocenopopuljacij kak funkcija vremeni i jenergii volnovyh processov [Age spectrum of phytocenopopulations as a function of time and energy wave processes]. Biological Sciences 2: 7-34.

Uranov A.A. \& Smirnova O.V., 1969, Klassifikacija i osnovnye cherty razvitija populjacij mnogoletnih rastenij [Classification and main features of perennial plant populations]. Bulletin of the Moscow Society of Naturalists. Biological Department 74(2): 119-134.
Vajari K.A., Jalilvand H., Pourmajidian M.R., Espahbodi K. \& Moshki A., 2012, Effect of canopy gap size and ecological factors on species diversity and beech seedlings in managed beech stands in Hyrcanian forests. Journal of Forestry Research 23(2): 217-222.

Vsevolodova-Perel T.S., 1997, Dozhdevye chervi fauny Rossii: kadastr i opredelitel' [Earthworms of the fauna of Russia: Cadastre and determinant]. Nauka, Moscow, $101 \mathrm{pp}$.

Watt A.S., 1947, Pattern and process in plant community. Journal of Ecology 35: 1-22.

Whitmore T.C., 1990, An introduction to tropical rain forests. Oxford University Press, Oxford, 226 pp.

WRB, World reference base for soil resources, 2015, International soil classification system for naming soils and creating legends for soil maps. World Soil Resources Reports No 106. FAO, Rome, 192 pp.

Yamamoto S.I., 2000, Forest gap dynamics and tree regeneration. Journal of Forest Research 5(4): 223-229.

Zaugolnova L.B., Zhukova L.A., Komarov A.S. \& Smirnova O.V., 1988, Cenopopuljacii rastenij (ocherki po populjacionnoj biologii) [Coenopopulations of plants (essays on population biology)]. Nauka, Moscow, $236 \mathrm{pp}$.

Zhang C., Zou C.J., Peltola H., Wang K.Y. \& Xu W.D., 2013, The effects of gap size and age on natural regeneration of Picea mongolica in the semi-arid region of Northern China. New Forests 44(2): 297-310.

World Flora Online, 2012, online version at http://www. worldfloraonline.org/ [Accessed: 12.11.2020)]. 


\title{
The population status of Lagochilus setulosus Vved. and its biochemical composition
}

\author{
Arystanbek Eshibaev ${ }^{1}$, Zhanar Aimenova ${ }^{2, *}$, Lyazzat Akynova ${ }^{3}$, \\ Lyazzat Nurseitova ${ }^{3}$, Aizhan Kopabaeva ${ }^{3}$
}

\author{
${ }^{1}$ ShymkentUniversity, Shymkent, 160031, Zhibekzholy street 131, Kazakhstan \\ ${ }^{2}$ Muhtar Auezov South Kazakhstan University, Shymkent, 160012, Tauke Khan avenue 5, Kazakhstan \\ ${ }^{3}$ South KazakhstanState Pedagogical University,Shymkent, 160012, \\ Baitursinov street 13, Kazakhstan \\ *corresponding author e-mail: aimenova.zhanara@gmail.com
}

Received: 30 January 2021 / Accepted: 15 March 2021

\begin{abstract}
This article describes endemic species of the genus Lagochilus growing in the territory of South Kazakhstan - Lagochilus setulosus Vved. Its biochemical composition, namely qualitative and quantitative composition of biologically active compounds was investigated. The established composition of substances indicates that this plant species can be used in pharmaceutical biotechnology to create a biological preparation with a hemostatic effect based on Lagochilus setulosus.
\end{abstract}

Keywords: Lagochilus setulosus, South Kazakhstan, leaves and flowers, hemostatic agent, biological active compounds, deterpenes, lagochilin, lagochirzin.

\section{Introduction}

Wild flora of South Kazakhstan is represented by more than 3000 species of vascular plants. According to scientists, $25 \%$ of them are medicinal plants. Many species are of practical value for the purposes of traditional and alternative medicine. However, the medicinal properties of many of them still remain unexplored.

There are more than 3000 plant species in the flora of South Kazakhstan, of which 553 are of interest as valuable natural sources of medicinal substances (Flora of Kazahstan, 1964). However, most of these plant species are still insufficiently known. Only a limited number of plant species are used in the domestic pharmaceutical and cosmetic industries. In this regard, the priority direction of research is to identify potential sources of biologically ac- tive compounds that will provide a long-term reliable raw material base for the pharmaceutical and cosmetology industries of Kazakhstan. Identification of the content of the main groups of important biologically active compounds in growing plant species will allow rational use of plant resources and will make it possible to significantly expand the range of herbal medicinal raw materials. Some of these plants are plants of the genus Lagochilus.

Plants of the genus Lagochilus belong to the Lamiaceae family and are represented by 35 species distributed mainly in Central Asia: in Kazakhstan, Iran, Afghanistan, Russia, Mongolia and China (Rehinger \& Hedzh, 1982). Some plants of this genus are used as hemostatic agents, for the treatment of allergic dermatoses (Panossian \& Wikman, 1982), and are also used as a medicine for clot retraction (Akopov, 1954) and glaucoma (Kadyroza, 1955). Among 
the various plant species of the genus Lagochilus, Lagochilus inebrians Bunge has long been used in folk medicine of the East as a medicinal plant due to its sedative properties (Perry et al., 2002).

However, according to Akopov I.E., Lagochilus setulosus has the most pronounced stimulating effect on the blood clotting process (Akopov, 1981). However, this type of plant is still insufficiently known and requires further biological and chemical research.

To solve this problem, we have already performed studies on the macro-and micromorphological features of Lagochilus setulosus (Aimenova et al., 2015a).As a result of the research, the anatomical structure of this plant was established using the method of scanning electron microscopy. Gandular trichomes were found.

Also was performed a comparative research of the macro - and microelement composition of Lagochilus inebrians and Lagochilus setulosus (Aimenova et al., 2014). As a result of research, it was found that these plants differ in the quantitative content of macro-and microelements. According to the content of trace elements, the plant Lagochilus inebrians surpasses Lagochilus setulosus, but the quantitative content of iron, magnesium, lithium, and aluminum is 2-3 times higher in Lagochilus setulosus. At the same time, of all the identified macro - and microelements in Lagochilus setulosus, as well as in Lagochilus inebrians, the percentage content contains the most calcium, which in the presence of lagochirzin fully implements the process of plasma hemostasis.

The next, necessary stage of the study of this plant species is the study of its distribution area, as well as the study of its biological composition.

\section{Objects and methods}

For the research, the flowers and leaves of Lagochilus setulosus were collected during the mass flowering period in July. To do this, the tops of the stems of plants $20-30 \mathrm{~cm}$ long were cut off, leaving 1-2 plants per $1 \mathrm{~m}^{2}$ for seeding and population renewal. Drying was carried out in the shade in a well-ventilated room, laying it out in a thin layer on a tarpaulin. Then, after drying, the stems were threshed with a wooden stick, separated and discarded. Then the yellowed and browned parts were removed and the raw materials were crushed in a mechanical shredder. Thus, the finished raw material contained flowers and leaves that retained their natural color.

Qualitative determination of the content of the main groups of biologically active substances in the phytomass of Lagochilus setulosus was performed according to the following methods:

1) The presence of diterpenes was determined by paper chromatography (Belenkij et al., 1983).
2) The presence of tannins was determined by a specific gelatin deposition reaction (Sumina et al., 2006).

3) The presence of essential oil was determined by the method described in State Pharmacopeia X (State Pharmacopoeia of USSR, 1968).

4) The presence of cardiac glycosides was determined by Keller-Kiliani Reaction (Syvkinet al., 1999).

5) The presence of saponins was determined by the reaction to foaming (Ladygina et al., 1983).

6) The presence of phenolglycosides was determined as follows (Petrov, 1978).

7) The presence of iridoids was determined by the method described in State Pharmacopeia XI (State Pharmacopoeia of USSR, 1989).

8) The presence of flavonoids was determined by cyanidin sample (Bandyukova, 1965).

9) The presence of coumarins was determined as follows: for the preparation of extraction from vegetable raw materials $2 \mathrm{~g}$ of crushed raw materials (crushed flowers and leaves of plants), $20 \mathrm{ml}$ of ethyl alcohol was poured and boiled for $15 \mathrm{~min}$ utes with a reflux. After cooling, filtered. To 3-5 $\mathrm{ml}$ of alcoholic extract was added 10 drops of $10 \%$ $\mathrm{KOH}$ in methanol and heated for $5 \mathrm{~min}$ in a water bath (solution turned yellow), then added 5 drops of freshly prepared diazo reagent of Pauli Kutochku. Further, the solution acquired a cherry color, which indicates the presence of coumarins.

10) The presence of anthracene derivatives was determined by the following method (Kurkin et al., 2016).

11) The presence of sugars was determined by the method (Fialkov, 1946).

12) The presence of alkaloids was determined by the method (Ladygina, 1983).

13) The presence of resinous substances was determined by the decrease in the mass of the sample after exhaustive extraction in the soxlet apparatus with a capacity of 11 for $20 \mathrm{~h}$ and subsequent drying to a constant weight at a temperature of $105^{\circ} \mathrm{C}$. Further, the method of fractionation using chloroform and acetone solvents was used to separate resinous substances (Kuznetsov et al., 2004).

Quantitative determination of the content of the main groups of biologically active substances of Lagochilus setulosus performed according to the following methods:

1) essential oil by the method of (State Pharmacopoeia of the USSR, 1968).

2) resinous substances by the method: the leaves and flowers of Lagochilus setulosus crushed to a particle size of 1-2 mm and subjected to extraction of non-polar solvent, hexanal to conventional Soxhlet extractions for the separation of resinous substances. The yield of resinous substances depending on the terms of raw mate- 
rial preparation and storage was $6-9 \%$ of the weight of the absolutely dry residue.

3) diterpene lagochilin according to the method: $10 \mathrm{~g}$ of finely powdered raw material (flowers and leaves of Lagochilus setulosus was placed in a $250 \mathrm{ml}$ flask and $100 \mathrm{ml}$ chloroform was poured. The flask with the contents was attached to the reflux and heated in a water bath for 1 hour. The extract was then cooled and filtered. In the same way chloroform extraction was repeated 5-6 times (from one raw material). Chloroform extracts were combined and chloroform distilled to produce a dry residue. $10 \mathrm{ml}$ of distilled water was added to the dry residue and heated $(5 \mathrm{~min})$ in a water bath, adding $15 \mathrm{ml}$ of $10 \% \mathrm{NaOH}$ and heated in a water bath for $30 \mathrm{~min}$. The water-alkaline mixture, after cooling, was repeatedly treated with ethyl ether (5-6 times). The combined essential extracts were concentrated to 10 $\mathrm{ml}$ and left for the crystallization of lagochilin, which was separated by filtration through a suspended filter, dried and weighed. Lagochilin recrystallization was performed with acetone.

4) diterpene lagochirzin by the method of water-alkaline solution, after removal of lagochilin neutralized with $20 \% \mathrm{H}_{2} \mathrm{SO}_{4}$ solution until slightly acid reaction $(\mathrm{pH}=5)$ and the mixture was repeatedly treated with chloroform (5-6 times). Chloroform extract was combined, concentrated and chloroform had tetroxide in distilled. The dry residue was obtained in an amount of $0.22 \mathrm{~g}$. It was passed through a column with $10 \mathrm{~g}$ of silica gel (column diameter $2 \mathrm{~cm}$, height $20 \mathrm{~cm}$ ) and eluted with a mixture of ethyl ether and petroleum ether (40:1). A total of 20 fractions $(5 \mathrm{ml})$ were obtained; 5-12 fractions containing lagochirzin (chromatography on plates "Sorbfil") were combined, evaporated, the dry residue was dried and weighed.

5) flavonoids by the following technique: the optical density of eluates was measured on a spectrophotometer in a cuvette with a layer thickness of $1 \mathrm{~cm}$ at a wavelength of $363 \mathrm{~nm}$ against the background of the eluate of the idle experiment. The percentage of routine in raw materials in terms of absolutely dry raw materials was calculated by the formula:

$$
\chi=\frac{K_{1} V_{1} V_{3} D_{363} 100}{V_{2} D_{c M}^{1 \%} m(100-w) \times 0,667 l}
$$

where:

$K_{1}$ - the ratio of elution (1.195);

$V_{1}$ - volume of ethanol extract after dissolution of dry residue; $\mathrm{ml}$;

$V_{2}$ - the volume of ethanol extract was taken for use on chromatogram, ml;

$V_{3}$ - the volume of eluate;

$D_{363}-$ optical density of solution at $\lambda=363 \mathrm{~nm}$;
$\mathrm{D} 1 \% / 1 \mathrm{~cm}-$ the rate of absorption of rutinat $\lambda=363 \mathrm{~nm}$ (268.4);

$m$ - the weight of the portion of the raw material, g;

$w$ - loss in weight of raw materials during drying, \%;

0.067 - conversion factor to $20 \mathrm{ml}$ of extract;

$l$ - layer thickness, $\mathrm{cm}$.

6) iridoids by the following technique: the content of the sum of iridoids in terms of harpagid and absolutely dry raw materials (\%) was calculated by the formula:

$$
x=\frac{A \times 100 \times 10 \times 25 \times 100}{56 \times m \times 20 \times 5 \times(100-W)}=\frac{A \times 25000}{56 \times m \times(100-W)},
$$

where:

A - optical density of the tested solution;

$\mathrm{m}$ - raw material linkage, g;

$\mathrm{W}$ - humidity of raw materials;

5. 56 - the rate of absorption of the reaction products with hydroxylamine and iron (III) chloride.

7) coumarins according to the technique. The optical density of the solutions was measured at the following wavelengths: isopimpinellin $-313 \mathrm{~nm}$, bergapten $-311 \mathrm{~nm}$. The percentage of izopimpinellin and bergapten was calculated by the formula:

$$
\mathrm{X}=\frac{V_{1} V_{3} D_{2} 1,045 \times 100}{V_{2} m E_{1 \mathrm{M}}^{1 \%}(100-w)},
$$

where:

$V_{1}$ - extraction volume, $\mathrm{ml}$;

$V_{2}$ - volume of extraction applied to the chromatogram, ml;

$V_{3}$ - the volume of eluate, $\mathrm{ml}$;

$m$ - the weight of the portion of the raw material, g;

$E \frac{1 \%}{1 C M}-$ specific absorption rate: isopimpinellin-518, bergapten-651;

$D_{2}-$ the optical density of the eluate;

$w-$ loss in weight of raw materials during drying, $\%$.

8) phenolglycosides by the following technique: $1 \mathrm{ml}$ of $0.1 \mathrm{~N}$. iodine solution corresponds to 0.01361 arbutin. The percentage of arbutin in plant material $\mathrm{x}$ in terms of absolutely dry raw materials was calculated by the formula:

$$
x=\frac{V 0,01361 \times 2 \times 100 \times 100}{m(100-w)},
$$

where:

$V$ - volume of $0.1 \mathrm{~N}$. iodine solution consumed for titration, $\mathrm{ml}$;

$m$ - the weight of the portion of the raw material, g; $w$ - loss in weight of raw materials during drying, $\%$. 
9) alkaloids by the following technique: The percentage in terms of absolutely dry raw materials $\mathrm{x}$ was calculated by the formula:

$$
x=\frac{(15-V) 0,005780 \times 100 \times 100}{m(100-w)},
$$

where:

$V$ - the volume of $0.02 \mathrm{n} \mathrm{NaOH}$ used for titration, $\mathrm{ml}$;

$m$ - the weight of the sample of raw materials corresponding to the volume of ether extraction, $g$;

$w-$ loss in weight of raw materials during drying, $\%$.

10) sugars by the method of Willstatter and Sudle. The optical density of the studied solution was recorded on a spectrophotometer at a wavelength $\lambda=582 \mathrm{~nm}$. The sugar content in the sample was determined by the calibration curve based on glucose. To do this, $50 \mathrm{ml}$ of a solution containing $10 \mathrm{mg} / \mathrm{ml}$ of glucose was prepared, and then the remaining solutions were obtained by dilution according to Table 1 .

Table 1. Method of dilution of the solution to obtain a glucose calibration curve

\begin{tabular}{|c|c|c|c|}
\hline Number & $\begin{array}{c}\text { Content } \\
\text { of glucose, } \\
\mathbf{m g} / \mathbf{m l}\end{array}$ & $\begin{array}{c}\text { Amount of initial } \\
\text { glucose solution, } \\
\mathbf{m l}\end{array}$ & $\begin{array}{c}\text { Amount } \\
\text { of water, } \mathbf{m l}\end{array}$ \\
\hline 1 & 0.5 & 0.5 & 9.5 \\
\hline 2 & 1.0 & 1.0 & 9.0 \\
\hline 3 & 2.5 & 2.5 & 7.5 \\
\hline 4 & 5.0 & 5.0 & 5.0 \\
\hline 5 & 7.5 & 7.5 & 2.5 \\
\hline 6 & 10.0 & 10.0 & 0 \\
\hline
\end{tabular}

The number of reducing sugars $(\mathrm{x})$ was calculated by the formula:

$$
x=\frac{c \times V}{m} \times 100 \%,
$$

where:

$c$-sugar content in the sample, found on the calibration curve;

$V$ - the volume of the extract obtained from the sample; $\mathrm{m}$ - weight of the sample in grams.

For isolating diterpene lagochirzin of phytomass Lagochilus setulosus we used the following method: $10 \mathrm{~g}$ of finely ground raw materials (flowers and leaves of Lagochilus setulosus) was placed in a $250 \mathrm{ml}$ flask and $100 \mathrm{ml}$ chloroform was poured. The flask with the contents was attached to the reflux and heated in a water bath for 1 hour. The extract was then cooled and filtered. In the same way chloroform extraction was repeated 5-6 times (from one raw material). Chloroform extracts were combined and chloroform distilled to produce a dry residue.

To the dry residue, $10 \mathrm{ml}$ of distilled water was added and heated ( $5 \mathrm{~min})$ in a water bath, then $15 \mathrm{ml}$ of $10 \%$ $\mathrm{NaOH}$ was added and heated in a water bath for $30 \mathrm{~min}$. The water-alkaline mixture, after cooling, was repeatedly treated with ethyl ether (5-6 times). The combined essential extracts were concentrated to $10 \mathrm{ml}$ and left for the crystallization of lagochilin, which was separated by filtration through a suspended filter, dried and weighed. Lagochilin recrystallization was performed with acetone. The aqueous-alkaline solution, after removal of lagochilin was neutralized with $20 \% \mathrm{H}_{2} \mathrm{SO}_{4}$ solution to a slightly acidic reaction $(\mathrm{pH}=5)$ and the mixture was repeatedly treated with chloroform (5-6 times). Chloroform extract was combined, concentrated and chloroform had tetroxide in distilled. The dry residue was obtained in an amount of $0.22 \mathrm{~g}$. the Dry residue was passed through a column with $10 \mathrm{~g}$ of silica gel (column diameter $2 \mathrm{~cm}$, height $20 \mathrm{~cm}$ ) and eluted with a mixture of ethyl ether-petroleum ether (40:1); 20 fractions $(5 \mathrm{ml})$ were obtained. 5-12 fractions contained lagochirzin (chromatography on plates "Sorbfil"), which were combined, evaporated, the dry residue was dried and weighed.

\section{Results and discussion}

The results of the taxonomic analysis established the distribution areas of plants of the genus Lagochilus in three floristic regions of the Turkestan region (Aimenova et al., 2015b).

At the same time, Lagochilus setulosus grows in the soil and climatic conditions of the foothill zone of the western Tien Shan, which is characterized by a moderate temperature regime, moisture availability and typical serozem.

Morphological features of Lagochilus setulosus are associated with the conditions of the place of growth of this species, which determines its characteristic macro- and micromorphological features. These features include the modification of the young leaves of the plant into spines, a reduction in the size of the leaves, the growth of sharp spines at the end of the leaves and sepals. The leaf epidermis is covered with a thick layer of cuticle, the mesophyll consists of 4 compressed layers of palisade tissue. The vegetative and generative organs are covered with glandular trichomes that produce a specific sticky substance around the seeds that keeps them moist.

Lagochilus setulosus is a semi-shrub, reaching a height of 20-60 cm. The root of the plant stem, the stems at the base stiffening, thin, glabrous or sparsely and protruding 
bristly, later white, shiny, $30-80 \mathrm{~cm}$ tall; leaves rhombic in outline, broadly ovate.

We found four populations of Lagochilus setulosus in the Kazygurt district (Turkistan Region in Southern Kazakhstan, whose administrative center is the village of $\mathrm{Ka}$ zygurt). The patches of plants vary from 1.3 to 4.5 ha. However, the density of plants in the area (coordinates $41.759^{\circ} \mathrm{N} 69.41^{\circ} \mathrm{E}$ ) is not high and it does not exceed $1.2 \pm 0.1$ plants per $\mathrm{m}^{2}$ (Fig. 1).

The projective cover of the soil with vegetation is no more than $15.3 \pm 1.3 \%$. Plants are found in individual specimens, bushy shape, height $35-40 \pm 1.7 \mathrm{~cm}$ in accordance with Figure 2 A, B.

The results of qualitative analyses of biological active substances presence are given in Table 2 .
As it can be seen from Table 2, in the phytomass of Lagochilus setulosus were identified 9 specific qualitative reactions to the presence of biologically active substances, which are important organic compounds used in pharmaceuticals, perfumery and medicine. However, among these substances we have not found tannins, anthracenes, saponins and cardiac glycosides. Qualitative reactions to these compounds showed negative results.

In the next stage of our research, the presence of previously identified biologically active substances in the phytomass of plants was tested in experiments with thin-layer paper chromatography. As studies have shown, all qualitative reactions were reliable, all of the biologically active substances listed in table 3 were identified by comparing the standard samples - «witnesses».



Figure 1. The total area of the populations of Lagochilus setulosus in Kazygurt district

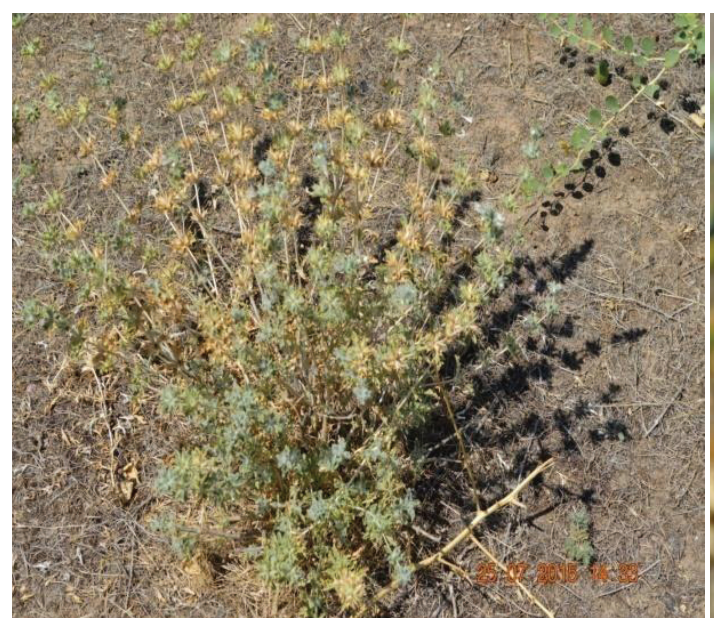

A) general view of the plant;

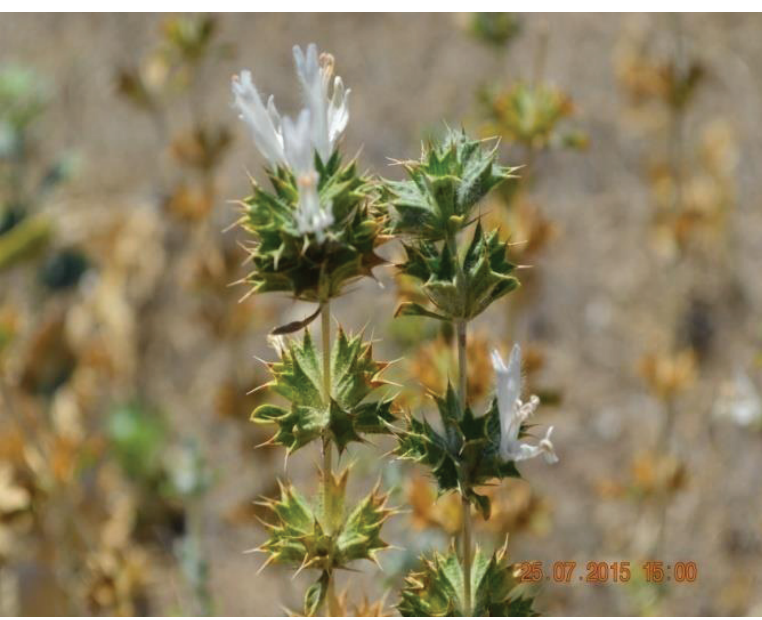

B) type of flowering plant shoot

Figure 2. Appearance of Lagochilus setulosus plants 
Table 2. Results of preliminary phytochemical screening of flowers and leaves of Lagochilus setulosus

\begin{tabular}{|c|c|c|}
\hline Number & Biologically active substance & $\begin{array}{c}\text { Qualitative } \\
\text { reaction }\end{array}$ \\
\hline 1 & tannins & not identified \\
\hline 2 & phenolic glycosides & Identified \\
\hline 3 & anthracenediones & not identified \\
\hline 4 & sugars & Identified \\
\hline 5 & saponines & not identified \\
\hline 6 & essential oil & Identified \\
\hline 7 & cardiac glycosides & not identified \\
\hline 8 & flavonoids & Identified \\
\hline 9 & coumarins & Identified \\
\hline 10 & resinous substance & Identified \\
\hline 11 & diterpenes & Identified \\
\hline 12 & iridoids & Identified \\
\hline 13 & alkaloids & identified \\
\hline
\end{tabular}

As shown by the results of quantitative studies in the phytomass of plants Lagochilus setulosus maximum measure have sugar (of $8.81 \%$ ), resinous substances (of $8.45 \%$ ), phenolic glycosides $(2.75 \%)$ and diterpenes $(2.43 \%)$. The content of the remaining compounds is below one percent $-0.11-0.81 \%$ (Table 3).

The established quantitative indicators of biologically active substances characterize the high pharmaceutical value of raw materials of plants of this species. Since these substances are usually synthesized in plants in small quantities, although they play a very important role in the metabolism of the body. The obtained quantitative indicators of biological active substances in plants of Lagochilus setulosus consistent with the results of other authors' research.

In the article of Akramov et al. (2019) is shown comparative study on the chemical composition and biological activities of the essential oils of three Lagochilus species collected from Uzbekistan. There are L. gypsaceus, L. inebrians and L. setulosus. L. gypsaceus was chosen by him to the study its phytochemical composition, which should be related to its most relevant biological properties. Studies of L. gypsaceus have revealed iridoid glycosides, diterpenes, flavonoids and sterols. Regarding diterpenoids - which, according to the conducted studies, determine the hemostatic function of plants of the genus Lagochilus, in L. gypsaceus only the diterpene lagochilin was found, while lagochirzin in its pure form is present in L. setulosus which grows in the territory of South Kazakhstan. Lagochirzin, which was previously synthesized from lagochilin as a result of multi-stage reactions, was performed by Zainutdinov on L. inebrians. L. setulosus is one of the rare plant species of this genus that contains lagochirzin in its pure form. This fact suggests a higher hemostatic activity of L. setulosus in comparison with L. gypsaceus (Zainutdinov, 1993).

Table 3. Results of the study of the quantitative content of the main groups of biologically active substances in the biomass of leaves and flowers of Lagochilus setulosus plants

\begin{tabular}{|c|c|c|}
\hline Number & $\begin{array}{c}\text { Biologically active } \\
\text { substance }\end{array}$ & $\begin{array}{c}\text { Quantitative content in \% } \\
\text { to weight of sample }\end{array}$ \\
\hline 1 & Essential oil & $0.12 \pm 0.004$ \\
\hline 2 & $\begin{array}{c}\text { Resinous } \\
\text { substances }\end{array}$ & $8.45 \pm 0.250$ \\
\hline 3 & $\begin{array}{c}\text { Diterpenes } \\
\text { Lagochilin } \\
\text { Lagochirzin }\end{array}$ & $0.75 \pm 0.005$ \\
\hline 4 & Flavonoids & $0.35 \pm 0.002$ \\
\hline 5 & Iridoids & $0.81 \pm 0.014$ \\
\hline 6 & Coumarins & $0.11 \pm 0.001$ \\
\hline 7 & Phenolic glycosides & $2.75 \pm 0.011$ \\
\hline 8 & Alkaloids & $0.70 \pm 0.002$ \\
\hline 9 & Sugars (in total) & $8.81 \pm 0.044$ \\
\hline
\end{tabular}

Phenolic glycosides, which were also found in L. setulosus, suggest the antioxidant activity of this plant. Since the literature data provides a clear link between the strong correlation between the total phenol content and the antioxidant (DPPH, CUPRAC, and FRAP) properties of the plant of the genus Lagochilus (Akramov et al., 2019).

In the study of Ebrahimi et al. (2020) also were investigated the total of 17 medicinal plants with hemostatic activity. The most frequently studied plant families were Compositae, Lamiaceae, Fabaceae, and Asteraceae. The majority of the plants were prepared in the form of aqueous or organic extracts of leaf, rhizome, flower, bark, pollen or the whole plant, and for some plants the active components were isolated. As a result, it was shown that the hemostatic activity of plant extracts is mainly attributed to several mechanisms, including coagulation stimulation via increasing the factor XII activity and plasma fibrinogen levels, the fibrinolysis inhibition, vascular or smooth muscle constriction and platelet aggregation. Ageratum conyzoides and Typha latifolia are the plants with the most in vivo and in vitro evidence of hemostatic activity. It is propounded that the bioactive compounds which are often 
involved in the bleeding control are categorized as tannins, saponins, glycosides and other phenolics. Moreover, the anti-fibrinolytic effect of browplasminin (tannin), 8-O-acetyl shanzhiside methylester (iridoid glycoside) and lignin were confirmed. Other isolated hemostatic compounds include glycoconjugate from Lythrum salicaria, saponins from Panax notoginseng, and Gallic acid, vanillic acid and luteolin from Sedum aizoon.

\section{Conclusion}

Thus, the distribution areas of plants of the genus Lagochilus were established in three floristic regions of the Turkestan region. Qualitative and quantitative analyses of the given biomass were carried out. The established composition of substances characterizes this type of plant as promising for use in pharmaceutical biotechnology in the creation of a biological drug with a hemostatic effect based on Lagochilus setulosus.

\section{References}

Aimenova Zh.E., Eshibaev A.A. \& Zaynutdinov U.N., 2015 b, Research of areas of distribution of valuable medicinal species of plants of Lagochilus Bunge (Lamiaceae) genus of South Kazakhstan Territory. The fourth European conference on Biology and Medical sciences, $13^{\text {th }}$ January 2015,Vienna, p. 4-9.

Aimenova Zh.E., Eshibaev A.A., \& Akynova L.A., 2015a, Research of macro- and micromorphological features of Lagochilus setulosus growing in the South Kazakhstan region. Bulletin of the L.N.Gumilyov Eurasian National University 4(107): 126-132 [in Russian].

Aimenova Zh.E., Zainutdinov U.N. \& Matchanov A.D, 2014, Active ingredients of the plant Lagochilus inebrians. Collection of materials of the international scientific and practical conference: Pharmaceutical education, science and production-a reference point for the strategy "Kazakhstan-2020", 23-24 October 2014. Conference Book No. 3(68), Vol II, p. 103-106, Shymkent, Republic of Kazakhstan [in Russian].

Akopov I.E., 1954, The effect of Lagochilus preparations on blood clotting. Bulletin of Experimental Biological Medicine 37: 49-54 [in Russian].

Akopov I.E., 1981, Hemostatic plants. "Medicine" UzSSR, Tashken, p.125-127 [in Russian].

Akramov D.Kh., Zengin G., Kang S.Ch., Tojibaev K.Sh., Mahomoodally M.F., Azimova S.S. \& Mamadalieva N.Z., 2019, Comparative study on the chemical composition and biological activities of the essential oils of three Lagochilus species collected from
Uzbekistan. Natural Product Research 2019. DOI: 10.1080/14786419.2019.1655417.

Akramov D.Kh., Bacher M., Böhmdorfer S., Rosenau T., Zengin G., Potthast A., Nahar L., Sarker S.D. \& Mamadalieva N.Z., 2020, Phytochemical analysis and biological evaluation of Lagochilus species from Uzbekistan. Industrial Crops \& Products 2020. https://doi. org/10.1016/j.indcrop.2020.112715.

Bandyukova V.A., 1965, The use of color reactions for the detection of flavonoids through chromatography on paper. Plant Resources 1(4): 591-597 [in Russian].

Belenkij B.G., Volynec M.P., Gankina E.S., 1983, Modern thin-layer chromatography. Journal of the All-Union Chemical Society 28(1): 30-34 [in Russian].

Ebrahimi F., Torbati M., Mahmoudi J., \& Valizadeh H., 2020, Medicinal Plants as Potential Hemostatic Agents. Journal of Pharmacy and Pharmaceutical Sciences 23(1): 10-23.

Fialkov Ya.A., 1946, Research methods of medicinal substances. Medgiz, Moscow, 255 pp. [in Russian].

Flora of Kazakhstan, 1964, Vol. VII. Nauka,Alma-Ata, 429 pp. [in Russian].

Kadyroza K.K., 1955, Lagochilusin the treatment of glaucoma. Bulletin of Ophthalmology 34: 32-35 [in Russian].

Kurkin V.A., ShmygarevaA.A. \&SańkovA.N., 2016, Development of new approaches to standardization of «Trostinka» collection. Scientific Statements of Belgorod State University, Series: Medicine. Pharmacy 33(5), 226 pp. [in Russian].

Kuznetsov B.N., Kuznetsova S.A. \& TarabańkoB.E., 2004, New methods of production of chemical products from biomass of Siberian trees. Russian Chemical Journal 48(3): 4-19 [in Russian].

Ladygina E.A., 1983, Chemical analysis of medicinal plants. High School Publishing House, Moscow, 152 pp. [in Russian].

Ladygina E.Ya., Safronich L.N. \& Otryashenkova V.E., 1983, Chemical analysis of medicinal plants: textbook for pharmaceutical universities. High School Publishing House, Moscow, 225 pp. [in Russian].

Panossian A, Wikman G., 2008, Pharmacology of Schisandra chinensis Bail.: an overview of Russian research and uses in medicine. J. Ethnopharmacol. 118(2): 183212. DOI: 10.1016/j.jep.2008.04.020. E-pub 2008 April 24, PMID: 18515024.

Perry E.K., Ashton H. \& Young A.H. (eds.), 2002, Neurochemistry of consciousness: neurotransmitters in the brain. John Benjamins Publishing Company, Amsterdam. e-Book ISBN: 9789027297891.

Petrov K.P., 1978, Methods of biochemistry of plant products. Higher School Publishing House, Kiev, 154 pp. [in Russian]. 
Rehinger K.H. \& Hedzh I.K., 1982, Flora of Iran, Labiatae. Academic Reference Book, Grac [in Russian].

State Pharmacopoeia of USSR, 1968, General methods of analysis. Medicine Publishing House, Series 10, Health Ministry of USSR, Moscow, 818pp. [in Russian].

State Pharmacopoeia of USSR, 1989, General methods of analysis. Medicine Publishing House, Series 11, Health Ministry of USSR, Moscow, 400 pp. [in Russian].

Sumina E.G., Shtykov S.H.\&Turina N.V., 2006, Thin-layer chromatography. Theoretical bases and practical appli- cation. Manual. N.G. Chernyshevsky Saratov National Research University, Saratov, 110 pp.

Syvkin A.I., Selemenev V.F. \& Suhoverhova E.A., 1999, Physico-chemical and biological methods of drug evaluation: textbook.Publishing House of Voronezh University, Voronezh, 368 pp. [in Russian].

Zainutdinov U.N., 1993, Diterpenes of Lagochilus genus plants. Dissertation for the degree of Doctor of Chemistry, 02.00.10, Tashkent State University, Tashkent, 339 pp. [in Russian]. 


\title{
Microbiological and genetic characteristics of Bacillus velezensis bacillibactin-producing strains and their effect on the sulfate-reducing bacteria biofilms on the poly(ethylene terephthalate) surface
}

\author{
Nataliia Tkachuk ${ }^{1, *}$, Liubov Zelena ${ }^{2}$, Oleksandr Lukash ${ }^{1}$, Pavlo Mazur $^{1}$ \\ ${ }^{1}$ T.H. Shevchenko National University “Chernihiv Colehium”, 53, Getman Polubotok Str., Chernihiv, Ukraine 14013 \\ ${ }^{2}$ Danylo Zabolotny Insitute of Microbiology and Virology, NAS of Ukraine 154, \\ Acad. Zabolotny Str., Kyiv, Ukraine, 03143 \\ *corresponding author e-mail: nataliia.smykun@gmail.com
}

Received: 9 March 2021 / Accepted: 2 April 2021

\begin{abstract}
It was evaluated the antibiofilm-forming properties of NUChC C1 and NUChC C2b isolates (from the collection of the Department of Biology of the T.H. Shevchenko National University "Chernihiv Colehium") against the sulfate-reducing bacteria biofilms on the poly(ethylene terephthalate) surface. NUChC $\mathrm{C} 1$ and $\mathrm{NUChC} \mathrm{C} 2 \mathrm{~b}$ isolates were isolated by classical microbiology methods on Postgate's "B" medium and their cultural-morphological, some physiological-biochemical properties and molecular-genetic characteristics were investigated. To identify bacteria the sequencing and analysis of the 16S rRNA gene were carried out. The bacteria were identified as Bacillus velezensis. Based on PCR-ISSR analysis, it was found that the studied bacteria belong to different strains. The 16S rRNA gene sequences were submitted in GenBank as MN508954.1 (NUChC C1), MN749356.1 and MN749357.1 (NUChC $\mathrm{C} 2 \mathrm{~b})$. In the genome of $B$. velezensis the presence and transcriptional activity of the genes for the synthesis of bacillibactin ( $d h b C$, $d h b F)$, fengycin $(f e n A)$ and polyglutamic acid (epsK) were studied. Among these only genes belonging to bacillibactin synthesis operon were detected and only they demonstrated activity. The observed mode of $d h b C$ and $d h b F$ genes expression during 144 hours of cultivation differed between two B. velezensis strains: gradually increasing in NUChC C1 and sharply increased after 24 hours with decreasing on 144th hour in NUChC C2b. Antagonistic properties of the studied strains of $B$. velezensis against sulfate-reducing bacteria Desulfovibrio oryzae NUChC SRB1 and NUChC SRB2 were not observed. Siderophore-producing strains of Bacillus velezensis inhibit the formation of bacterial biofilms on the polymeric material poly(ethylene terephthalate) during its long-term exposure (50 days) in a culture of sulfate-reducing bacteria under conditions of sufficient iron supply. Bacillibactin-producing strains prevent the development of bacterial biofilms on the poly(ethylene terephthalate) surface. This is one of the reasons for the prolongation of the process of poly(ethylene terephthalate) biodegradation in natural ecosystems.
\end{abstract}

Keywords: Bacillus velezensis; biofilm; Desulfovibrio oryzae; bacillibactin; gene expression; poly(ethylene terephthalate).

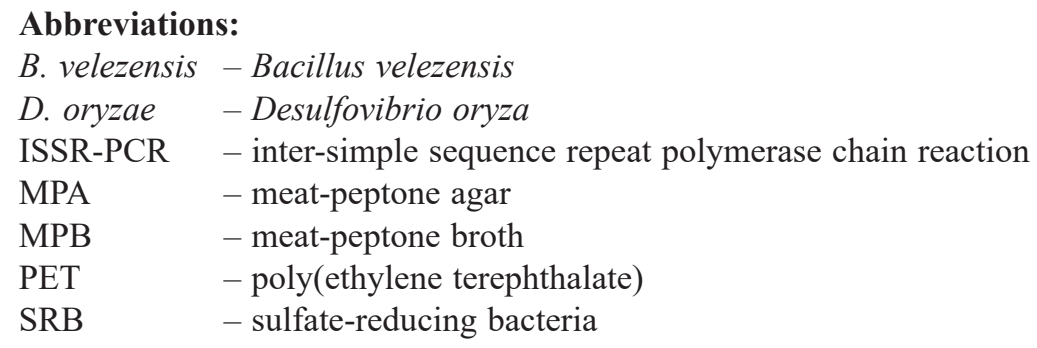




\section{Introduction}

Bacteria on surfaces grow in the form of a biofilm (Bhinu, 2005). Due to the high biochemical activity and the ability to form biofilms, bacteria are actively involved in the degradation of polymeric materials (Saveliev et al., 2011; Rogers et al., 2020). A significant amount of polymeric materials is represented by poly(ethylene terephthalate) (PET), the production of which is growing every year: 2 million tons/year in 2007 and 10 million tons/year in 2012 (Andrushkiv et al., 2012).

Plastic PET bottles are the most common type for packaging soft drinks and water (Filella, 2020). In Ukraine in 2018, out of 203.7 thousand tons of PET bottles that became waste, only 50 thousand tons ended up in waste processing plants (about 25\%), the other 75\% were buried in landfills (Burak \& Kyrychenko, 2020). In addition, due to the low level of environmental awareness and education of the population, a significant part of the used PET-bottles does not end up in landfills, but in natural ecosystems (Lukash, 2015).

The linear structure of PET and the high proportion of aromatic components are chemically inert and increase the strength of the polymer, making it very resistant to degradation by microorganisms (Yoshida et al., 2016). The ability to biodegrade PET is inherent in a small number of species of microorganisms (Yoshida et al., 2016; Vague et al., 2019; Chen et al., 2020; Shulga et al., 2020). The accumulation of PET in the environment creates a global environmental problem (Chen et al., 2020). Among the microorganisms isolated from the plastic surface, there are representatives of sulfate-reducing bacteria (Rogers et al., 2020). Previously, sulfate-reducing bacteria (SRB) Desulfovibrio oryzae were identified as participants in the damage of the metal construction in the soil (Tkachuk et al., 2020).

A number of researchers point out that $\mathrm{Fe}^{3+}$ plays an important role in the formation of microbial biofilms, and the depletion of iron in the environment can slow its formation (Pelchovich et al., 2013; Ali \& Wakte, 2016). Siderophores are low molecular weight compounds that chelate $\mathrm{Fe}^{3+}$ ions, converting iron bound to proteins or water-insoluble compounds into the ionic form of $\mathrm{Fe}^{3+}$ available to microorganisms (Leonov et al., 2016). Many aerobic and facultative anaerobic microorganisms are able to synthesize siderophores, the presence of which changes the structure of the microbial community (Saha et al., 2016).

However, at the moment there are no studies of the processes of SRB biofilms formation on the poly(ethylene terephthalate) surface under the influence of siderophoreproducing strains, therefore, that was an aim of this investigation.

\section{Material and methods}

\subsection{Microorganisms and growing conditions}

Five-day pure cultures of SRB Desulfovibrio oryzae strains NUChC SRB1 and NUChC SRB2, previously isolated from the sulfidogenic community isolated from the soil ferrosphere were used (Tkachuk et al., 2020). The nucleotide sequences were deposited in the GenBank with accession numbers MT102713.1 and MT102714.1 respectively.

To prepare the initial amount of bacteria, they were grown in Postgate's " $C$ " liquid medium (without adding Fe (II) salt) under anaerobic conditions, which were created by pouring the medium to the edges of the tubes and closing them with rubber stoppers. Suspensions with an optical density of $0.5 \mathrm{McF}$ arland were prepared from cultures of the studied strains in sterile isotonic sodium chloride solution. Further we used Postgate's "C" agar or liquid medium with adding Fe (II) salt.

Also in the study NUChC $\mathrm{C} 1$ and NUChC C2b isolates from the collection of the Department of Biology of the T.H. Shevchenko National University "Chernihiv Colehium" were used. Isolation of pure cultures of NUChC C1 and NUChC C2b was performed by the depleting stroke method on Postgate's "B" agar medium. Incubation was carried out under aerobic conditions and a temperature of $29 \pm 2{ }^{\circ} \mathrm{C}$ for 48 hours. The material of the two isolated colonies (NUChC $\mathrm{C} 1$ and NUChC $\mathrm{C} 2 \mathrm{~b}$ isolates) was reseeded into Postgate's "B" liquid medium and incubated under aerobic conditions. After five passages on Postgate's "B" medium, NUChC C1 and NUChC C2b isolates were obtained and used in further studies. The purity of the cultures was checked by microscopy. Bacteria were cultured on meat-peptone agar or meat-peptone broth for 24 hours, 120 hours and 144 hours (specified in each study respectively) aerobically at $29 \pm 2{ }^{\circ} \mathrm{C}$.

\subsection{Detection of bacillibactin ( $d h b C, d h b F)$, fengycin $(f e n A)$ and polyglutamic acid (epsK) synthesis genes in the genome of NUChC $\mathrm{C1}$ and NUChC $\mathrm{C} 2 \mathrm{~b}$ isolates}

Genomic DNA from 24-hour cell cultures of NUChC C1 and NUChC C2b was isolated with GeneJet Genomic DNA Purification Kit (ThermoScientific) according to manufacturer's protocol. The $20 \mu \mathrm{l}$ of PCR reaction mixture contained $10 \mu \mathrm{l}$ of $2 \mathrm{x}$ DreamTaq PCR Master Mix (ThermoScientific), $30 \mathrm{pmol}$ of each primer, and $50 \mathrm{ng}$ of DNA. Amplification was performed at the following temperature: initial denaturation $-5 \mathrm{~min}, 95{ }^{\circ} \mathrm{C} ; 30$ cycles $-10 \mathrm{sec}$, $95{ }^{\circ} \mathrm{C}$; $20 \mathrm{sec}, 57{ }^{\circ} \mathrm{C}$; $35 \mathrm{sec}, 72{ }^{\circ} \mathrm{C}$; final elongation $7 \mathrm{~min}, 72^{\circ} \mathrm{C}$. PCR was performed on Mastercycler Personal 5332 (Eppendorf, Germany). PCR products were checked by separating in $1.7 \%$ agarose gel with ethidium bromide. 
Nucleotide sequences of primers for amplification of $d h b C, d h b F$, eps $K$ and $f e n A$ genes fragments were selected using MEGA6 (Tamura et al., 2013) and Primer3 programs based on known sequences of these genes in representatives of Bacillus subtilis group (Table 1).

Table 1. The oligonucleotides used in the study

\begin{tabular}{|c|c|c|}
\hline Primer & Sequence, 5' - 3' & Reference \\
\hline $\begin{array}{l}d h b C 1 \\
d h b C 2\end{array}$ & $\begin{array}{l}\text { GGAACACCGACTGATCTTGC } \\
\text { CACAACGGATGGTCACGATC }\end{array}$ & This study \\
\hline $\begin{array}{l}d h b F 1 \\
d h b F 2\end{array}$ & $\begin{array}{c}\text { ACCCAGCTGCAAAATCAAGG } \\
\text { TCGCCGCTTCAAAATCTAGC }\end{array}$ & This study \\
\hline $\begin{array}{l}\text { fenA1 } \\
\text { fenA2 }\end{array}$ & $\begin{array}{l}\text { GACAGGGGCTGTCTCTGAAG } \\
\text { TGCATCCCTGATAAAAAGGC }\end{array}$ & $\begin{array}{l}\text { (Grabova et al., } \\
\text { 2016) }\end{array}$ \\
\hline $\begin{array}{l}\text { eps } K 1 \\
\text { epsK2 }\end{array}$ & $\begin{array}{l}\text { CATGGTTTACGTTCCGGGTG } \\
\text { AGCGGAAACTGAATGATCGC }\end{array}$ & This study \\
\hline
\end{tabular}

\subsection{Analysis of $d h b C$ and $d h b F$ genes expression and determining the number of catecholate-type siderophores in supernatant from MPB cultures of NUChC C1 and NUChC C2b}

To analyze gene expression bacterial cells of two strains were cultivated for 144 hours in MPB at $29 \pm 2{ }^{\circ} \mathrm{C}$. Samples for the analysis were taken after 24 hours and 144 hours of cultivation. RNA was isolated using TRIzol Reagent (Invitrogen) according to the manufacturer' protocol and followed by DNaseI treatment. cDNA was synthesized from $1 \mu \mathrm{g}$ of RNA using random hexanucleotide primers and M-MLV reverse transcriptase. The total volume of qPCR reaction mix was $10 \mu \mathrm{l}$ and contained $5 \mu \mathrm{l}$ of PowerUp ${ }^{\mathrm{TM}}$ SYBR $^{\mathrm{TM}}$ Green Master Mix (Applied Biosystems ${ }^{\mathrm{TM}}$ ), 20 pmol of each primer and $2 \mu \mathrm{l}$ of cDNA template. qPCR was performed with QuantStudio ${ }^{\text {TM }} 3$ Real-Time PCR System (Applied Biosystems) under temperature conditions recommended by the manufacturer. 16S rRNA gene was considered as endogenous reference (Zelena et al., 2014). No template control and duplicate samples for each gene (16S rRNA, $d h b C$ and $d h b F$ ) were included in the run. Relative genes expression level was calculated with $2^{-\Delta \Delta \mathrm{Ct}}$ method (Livak \& Schmittgen, 2001) with QuantStudio ${ }^{\mathrm{TM}}$ Real-Time PCR software program (Applied Biosystems). The statistical significance of gene expression between samples was calculated using t-test. The primer specificity and dimer formation were checked with melting curve analysis.

Neilands spectrophotometric testing was used to determine the content of siderophores of the catecholate type (which includes bacillibactin) (Sujatha \& Ammani, 2013). We measured the absorbance at $490 \mathrm{~nm}$, consistent with the data from Sujatha \& Ammani (2013), that at this wavelength the absorption maximum indicates the presence of catecholate siderophores.

\subsection{Determination of antagonistic properties of $\mathrm{NUChC} \mathrm{C} 1$ and $\mathrm{NUChC} \mathrm{C} 2 \mathrm{~b}$ isolates against sulfate-reducing bacteria}

The method of filling bacterial colonies of NUChC $\mathrm{C} 1$ and NUChC $\mathrm{C} 2 \mathrm{~b}$ isolates with agar medium containing the test organisms (D. oryzae NUChC SRB1 and NUChC SRB2) was used (Egorov, 1965). For this purpose, daily cultures of NUChC C1 and NUChC C2b isolates were sown with a Drygalski spatula on the surface of meat-peptone agar in Petri dishes to obtain separate colonies. After the colonies of microorganisms were well developed (growing in a thermostat for 120 hours at a temperature of $29 \pm 2$ ${ }^{\circ} \mathrm{C}$ ), around the colonies that were grown, Postgate's " $\mathrm{C}$ " agar medium was poured with added test-organisms - SRB D. oryzae strains NUChC SRB1 and NUChC SRB2 $\left(10^{6}\right.$ cells/ml medium).

After solidification of the medium with test-cultures anaerobic conditions were created by the method of Shturm L.D. in the modification of Duda V.I. (Zvyagintsev et al., 2005). Petri dishes were placed at $29 \pm 2{ }^{\circ} \mathrm{C}$ for 5 days. The development of bacterial test-cultures was visually observed.

\subsection{A biofilm assay}

To study the intensity of biofilm formation on the PET surface, $10 \times 10 \mathrm{~mm}$ samples of PET were cultured in Postgate's " $C$ " liquid medium ( $76 \%$ of the volume) with the addition of meat-peptone broth (MPB) or a supernatant from MPB cultures of NUChC C1 isolate (or NUChC C2b isolate) obtained after centrifugation for $10 \mathrm{~min}$ at 10,000 rpm ( $22 \%$ of the volume) and a culture of D. oryzae NUChC SRB1 (2\% of the volume) during 50 days.

A biofilm assay (indirect measurement of bacterial biofilm biomass by crystal violet adsorption/desorption) was used (Stepanović et al., 2000). The strains were classified into adhesion categories as was described by Stepanović et al. (2000). Statistical analysis of the obtained results was performed using the statistical module of Microsoft Office Excel 2010.

\subsection{Identification of $\mathrm{NUChC} \mathrm{C} 1$ and $\mathrm{NUChC} \mathbf{C 2 b}$ isolates}

Investigation of cultural-morphological and some physiological-biochemical properties of isolates. Light microscopy (Delta Optical Genetic Pro microscope) at magnification $(\times 400$ and $\times 1000)$ and electron microscopy (BS-540 electron microscope) (Tesla, Czechoslovakia) at $\times 16000$ magnification were used to study the morphology of NU- 
ChC C1 and NUChC C2b bacteria. Preparations of microbial cells were Gram-stained in the Kalina's modification to determine gram affiliation by Hansen's method for staining spores (Dikiy et al., 2002). The strains were grown on Postgate's "B" medium, meat-peptone broth (MPB) and meat-peptone agar (MPA). Morphological analysis of colonies was performed according to the conventional scheme. Studies of the presence of catalase and oxidase were performed by conventional methods (Dikiy et al., 2002).

Molecular-genetic analysis of isolated strains. To identify bacteria the sequencing and analysis of 16S rRNA gene were carried out. DNA isolation, amplification with $27 \mathrm{~F}$ and $1492 \mathrm{r}$ primers, sequencing of $16 \mathrm{~S}$ rDNA in both directions, phylogenetic analysis procedures were performed as described in (Tkachuk et al., 2017). The nucleotide sequences were deposited in GenBank as Bacillus velezensis with accession numbers MN508954.1 (NUChC C1), MN749356.1 and MN749357.1 (NUChC C2b). The basic sequence statistics of $16 \mathrm{~S}$ rDNA, including conserved sites, variable sites, parsimony informative sites, singleton sites and calculation of pairwise distances were analyzed with MEGA6 software (Tamura et al., 2013).

Genome variability and strain differentiation were analyzed by ISSR-PCR (Inter-simple sequence repeat polymerase chain reaction) (Tkachuk et al., 2020).

\section{Results and discussion}

\subsection{Microbiological characteristics of NUChC C1 and NUChC C2b isolates}

Colonies of NUChC $\mathrm{C} 1$ isolate when cultured on Postgate's "B" agar medium under aerobic conditions were superficial, of grayish-beige color, irregular shape, solid consistency, size 3-4 $\mathrm{mm}$. The edges of the colonies were wavy, the structure is fine-grained, the center of the colonies was darker than the edges.

On the MPA, the colonies of NUChC C1 and NU$\mathrm{ChC} \mathrm{C} 2 \mathrm{~b}$ isolates had a diameter of 3 and $1 \mathrm{~mm}$, respectively, were of beige color, round ( $\mathrm{NUChC} \mathrm{C1)} \mathrm{or} \mathrm{irregular}$ shape (NUChC C2b) (Fig. 1). The profile of the colonies is flattened, the surface is shiny, smooth, the structure is fine-grained. The edges of the colonies are uneven, wavy. The consistency is soft. Bacteria are gram-positive motile rods with rounded ends, peritrichous, $8.0 \pm 0.9 \mu \mathrm{m}$ long (NUChC C1) and $7.0 \pm 0.5 \mu \mathrm{m}$ (NUChC C2b), single, in pairs or chains (4 or more cells), form endospores (Fig. 1).

Both isolates are catalase-positive and oxidase-negative.

Therefore, microbiological characteristics according to Bergey's Manual of Systematic Bacteriology (De Vos et al., 2009) prove that the isolated bacteria can belong to the Bacillus genus.

\subsection{Genome variability of the new isolates}

The results of PCR-ISSR analysis are presented in Figure 2. The comparison of the sets of amplification fragments obtained (in number and size) between isolates showed the presence of common and unique for each sample amplicons. The size of PCR products ranged from 600 to 3000 bp $\left((\mathrm{GA})_{9} \mathrm{C}\right)$ and from 300 to $2000 \mathrm{bp}\left((\mathrm{GA})_{8} \mathrm{~T}\right)$. The total spectrum of amplification products with primer $\left((\mathrm{GA})_{9} \mathrm{C}\right)$ consisted of 7 fragments, 3 of which were polymorphic. The percentage of polymorphic loci using primer $(\mathrm{GA})_{8} \mathrm{~T}$ was $62.5 \%, 5$ of 8 amplicons. Thus, the bacteria NUChC $\mathrm{C} 1$ and NUChC $\mathrm{C} 2 \mathrm{~b}$ do belong to different strains.
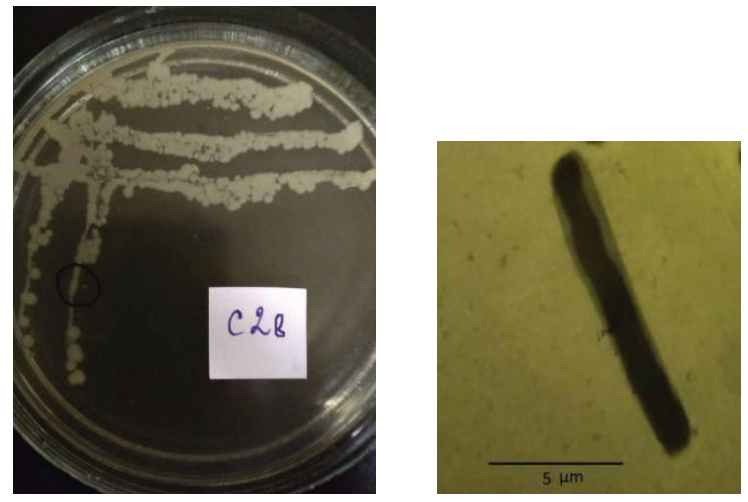

b

Figure 1. Test isolates (colonies on MPA (24 hours) and microphotographs of the cells (electron microscopy, $\times 16000)$ : a $-\mathrm{NUChC}$ $\mathrm{C} 1 ; \mathrm{b}-\mathrm{NUChC} \mathrm{C} 2 \mathrm{~b}$ (scale bar: $5 \mu \mathrm{m}$ ) 
3.3. The presence and activity of bacillibactin, fengycin and polyglutamic acid synthesis genes in the genome of NUChC $\mathrm{C} 1$ and NUChC $\mathrm{C2b}$ strains

Bacillus bacteria are known to be widespread in the environment, including soil, and are able to produce a variety of important natural substances (Saxena et al., 2020). They are used to improve plant growth and development and as biocontrol agents, due to their ability to synthesize substances with antifungal, antibacterial and nematocidal activity (Mongkolthanaruk, 2012; Ramlucken et al., 2020; Saxena et al., 2020). Such substances include cyclic lipopeptide fengycin, siderophore bacillibactin (Mongkolthanaruk, 2012) and polyglutamic acid (Hsueh et al., 2017).

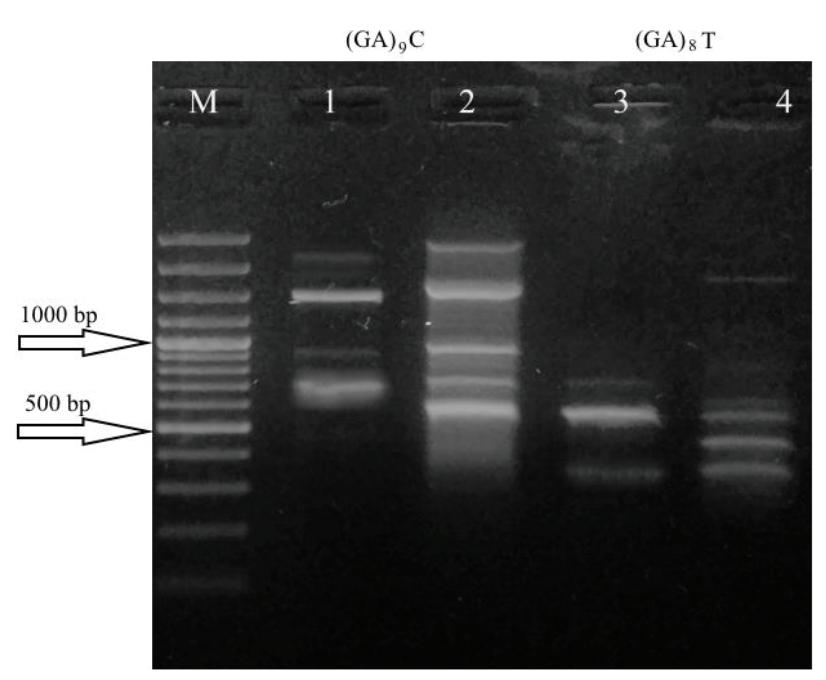

Figure 2. The electrophoregram of amplification products with primers to short nucleotide repeats: $\mathrm{M}-\mathrm{DNA}$ ladder (ThermoScientific); 1, 3 - NUChC C1; 2, 4-NUChC $\mathrm{C} 2 \mathrm{~b}$
The study of the presence of genes for the synthesis of bacillibactin $(d h b C, d h b F)$, fengycin $(f e n A)$ and polyglutamic acid (epsK) in the genome of isolates showed that the studied strains have only the gene for the synthesis of bacillibactin (Fig. 3). Bacillibactin biosynthesis relies on the $d h b A-F$ operon encoding enzymes that carry out four sequential reactions converting 3-chorismate to bacillibactin (Abe et al., 2019; Qin et al., 2019). Comparative analysis of $d h b C$ and $d h b F$ genes expression revealed differences in mRNA abundance between two strains. NUChC $\mathrm{C} 2 \mathrm{~b}$ strain demonstrated the higher transcriptional activity after 24 hours of cultivation compared to NUChC C1 strain but the level of $d h b C$ and $d h b F$ expression was decreasing on $144^{\text {th }}$ hour in NUChC C2b strain while it was still increasing in NUChC C1 strain (Fig. 4).

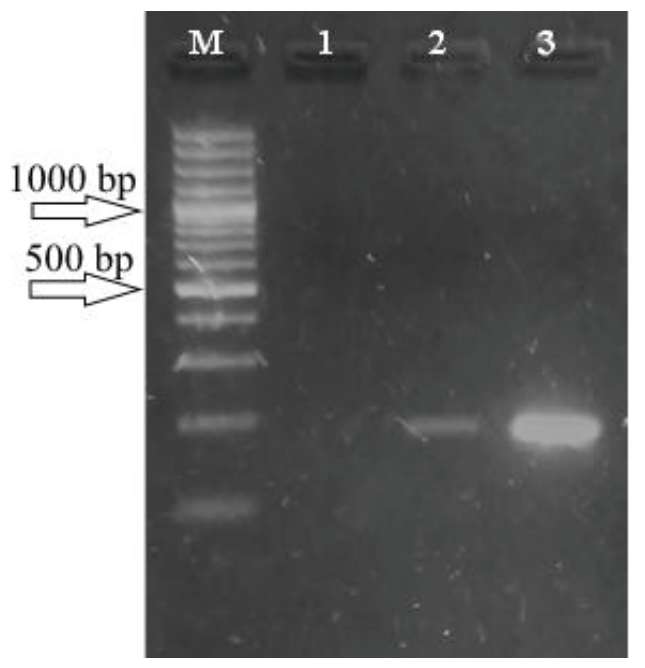

Figure 3. The electrophoregram of amplification products of the $d h b F$ gene fragment. $\mathrm{M}-$ a molecular weight marker; 1 - the negative control; 2 - NUChC C1; 3 - NUChC $\mathrm{C} 2 \mathrm{~b}$

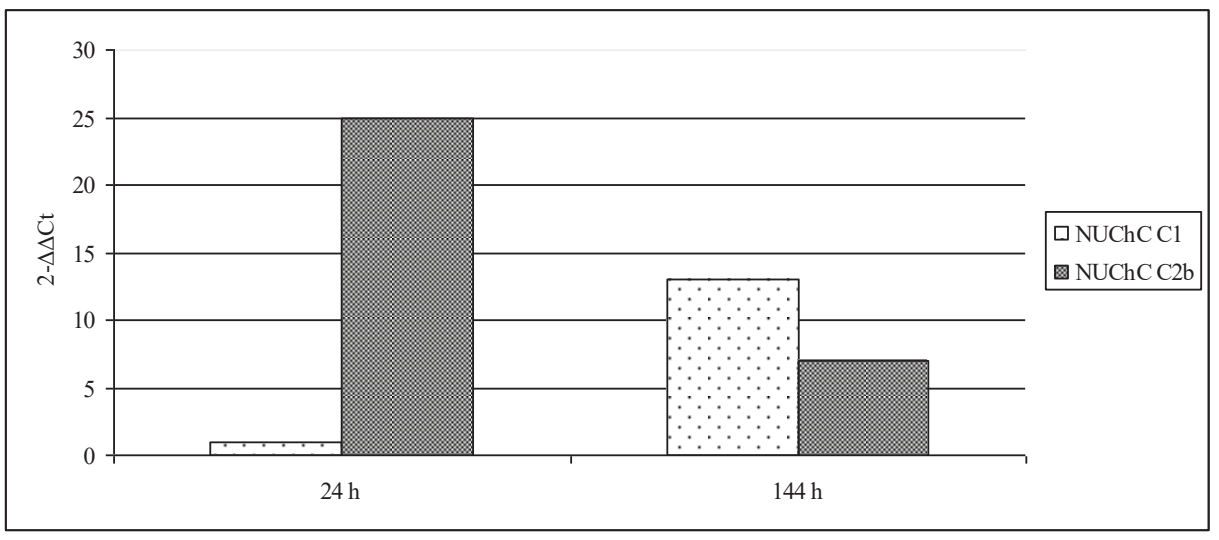

Figure 4. Relative total $d h b C$ and $d h b F$ genes expression level in test strains. The least total gene expression level was taken as 1 (NUChC $\mathrm{C} 1)$. The differences between strains are statistically significant at $\mathrm{p} \leq 0.05$ 
The results of the investigation of the number of siderophores of the catecholate type in the culture fluid of the studied strains are shown in Table 2.

Table 2. Optical density $\left(\mathrm{OD}_{490}\right)$ of the supernatant of the studied NUChC $\mathrm{C} 1$ and $\mathrm{NUChC} \mathrm{C} 2 \mathrm{~b}$ strains by spectrophotometric testing of Neilands

\begin{tabular}{|l|c|c|}
\hline \multirow{2}{*}{ A variant of the experiment } & \multicolumn{2}{|c|}{ OD } \\
\cline { 2 - 3 } & $\mathbf{2 4}$ hours & $\mathbf{1 4 4}$ hours \\
\hline MPB (without bacteria) & 0.045 & 0.050 \\
\hline $\begin{array}{l}\text { Supernatant from MPB culture } \\
\text { of NUChC C1 }\end{array}$ & 0.050 & 0.055 \\
\hline $\begin{array}{l}\text { Supernatant from MPB culture } \\
\text { of NUChC C2b }\end{array}$ & 0.064 & 0.063 \\
\hline
\end{tabular}

It was found that optical density of the supernatant from MPB culture of NUChC C2b strain is $15-28 \%$ higher than NUChC C1 strain (Table 2). This indicates a higher number of catecholate-type siderophores in NUChC C2b strain culture at both the 24th and 144th hours of cultivation.

\subsection{The intensity of biofilm-formation and growth of $D$. oryzae under the influence of NUChC C1 and NUChC C2b strains}

A number of researchers point to the fact that bacteria of the genus Bacillus are able to inhibit the development of microorganisms that actively biodegrade materials and their formation of biofilms (Jayaraman et al., 1999a; Jayaraman et al., 1999b; Ornek et al., 2002; Korenblum et al., 2008; Bano \& Qazi, 2011; Korenblum et al., 2012; Du et al., 2014; Aïmeur et al., 2015; Wadood et al., 2015).

Therefore, we investigated the intensity of SRB biofilm formation on the surface of PET samples in the presence of a supernatant from MPB cultures of NUChC $\mathrm{C} 1$ and

NUChC C2b, which contained siderophore bacillibactin. The results are presented in Figure 5 and 6.

It was found that the supernatant of the studied NUChC $\mathrm{C} 1$ and NUChC C2b strains significantly inhibits (2 times) the formation of a biofilm on the surface of PET bacteria D. oryzae NUChC SRB1 (Fig. 6). It should be noted that the inhibition of SRB biofilm formation on PET by the supernatant of both strains was the same, despite the observed different level of expression of bacillibactin siderophore synthesis genes and the difference in the number of catecholate-type siderophores (Fig. 4, Table 2). Thus, a supernatant from MPB cultures of NUChC $\mathrm{C} 1$ and NUChC $\mathrm{C} 2 \mathrm{~b}$ strains inhibits the formation of SRB biofilm on the poly(ethylene terephthalate) surface.

Therefore, we further investigated the antagonistic properties of our isolates against SRB D. oryzae. The experiment was performed by filling the antagonist colonies with Postgate's " $\mathrm{C}$ " agar medium containing test-organisms. It was found that SRB D. oryzae strains NUChC SRB1 and NUChC SRB2 develop around colonies of isolates - sterile areas are absent. Therefore, the antagonistic properties of the studied isolates against SRB were not observed.

\subsection{Identification of isolates by $16 \mathrm{~S}$ rRNA gene sequence analysis}

As a result of molecular-genetic analysis of isolates, fragments of the 16S rRNA gene with a size of $567 \mathrm{bp}$ (NUChC C1), 665 and 179 bp (NUChC C2b) were sequenced. The initial comparison of the obtained sequences using the BLAST program showed $99 \%$ similarity with different members of the genus Bacillus: B. methylotrophicus, B. amyloliquefaciens subsp. plantarum, B. velezensis. Based on the nucleotide sequences of the 16S rRNA gene of type strains of the most similar species and studied isolates using the Neighbor-Joining algorithm and the two-parameter Kimura's model, a dendrogram of genetic similarity was constructed (Fig. 7).

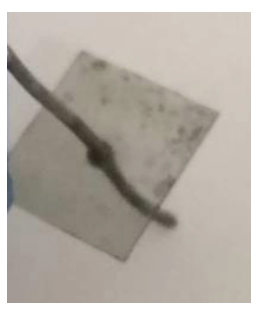

c



d

Figure 5. Samples of PET with the formed biofilm of sulfate-reducing bacteria: $a-$ control; $b-\mathrm{SRB} 1 ; \mathrm{c}-\mathrm{SRB} 1+\mathrm{C} 1 ; \mathrm{d}-\mathrm{SRB} 1+\mathrm{C} 2 \mathrm{~b}$ 


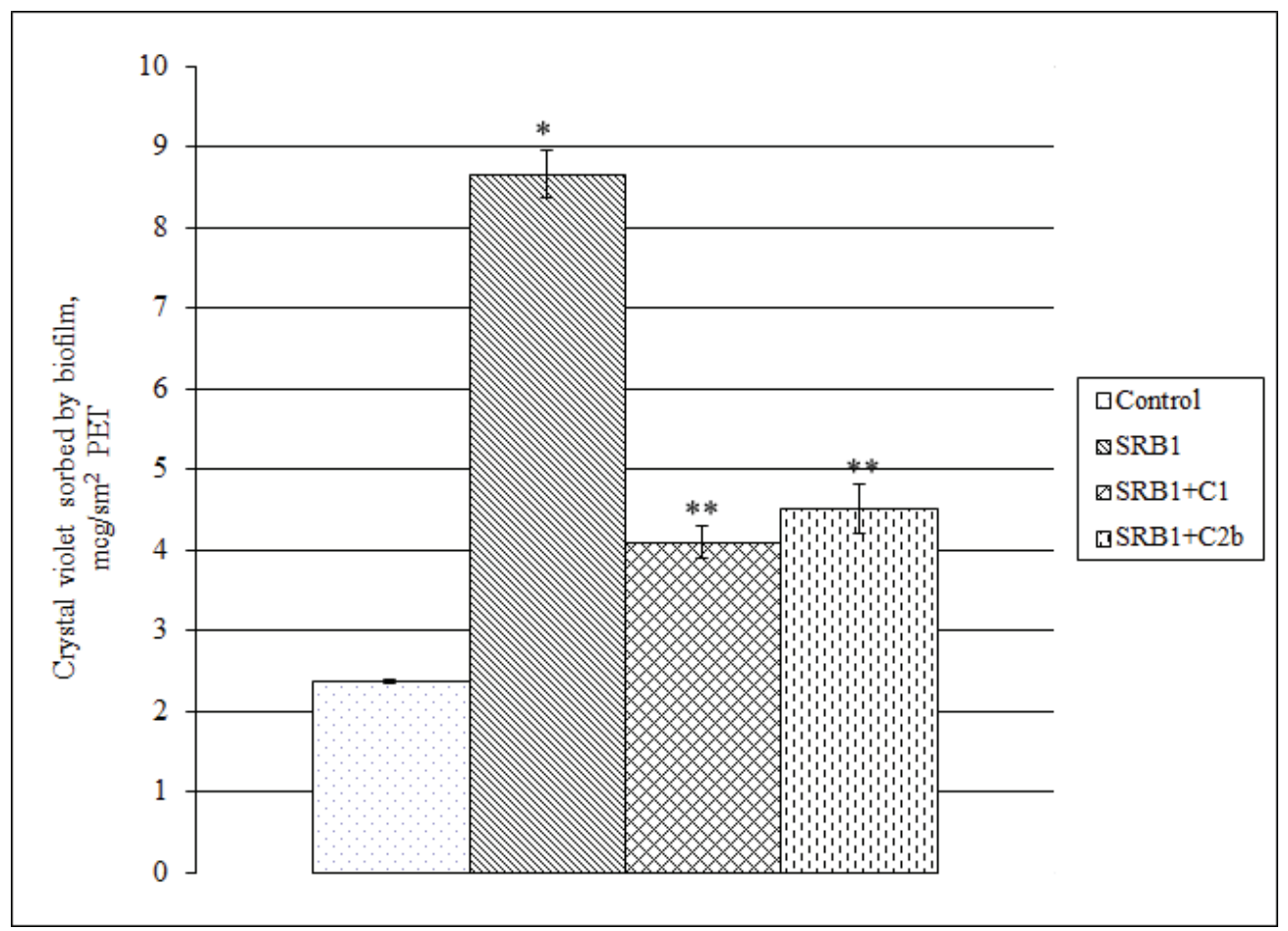

Figure 6. Biofilm-forming ability of sulfate-reducing bacteria of strain D. oryzae NUChC SRB1 on the poly(ethylene terephthalate) in the presence of supernatant from MPB cultures of NUChC C1 and NUChC C2b (50 days of cultivation). Note: the differences are significant * compared to the control, ** compared to the control and SRB1 at $\mathrm{p} \leq 0.05$



Figure 7. Results of phylogenetic analysis of isolates of NUChC C1 and NUChC C2b and other members of the genus Bacillus 
All these species of the genus Bacillus combined into one cluster. As can be seen from Figure 7, isolates of NUChC $\mathrm{C} 1$ and NUChC C2b were included in one subcluster with the species Bacillus velezensis, which confirms their belonging to this species. It should be noted that today the species names of $B$. amyloliquefaciens subsp. plantarum, B. methylotrophicus, "B. oryzicola", $B$. methylotrophicus subsp. plantarum are accepted as heterotypic synonyms of $B$. velezensis (Dunlap et al., 2016; NCBI, 2019).

Therefore, NUChC $\mathrm{C} 1$ and NUChC C2b isolates have been identified as Bacillus velezensis for a number of microbiological and genetic characteristics.

Antibiofilming and antifouling properties of $B$. velezensis bacteria have been noted in the works of a number of researchers (Khan et al., 2016; Wang et al., 2019; Yoo et al., 2019). In particular, B. velezensis WY has the ability to quench the quorum sensing due to the significant activity of degradation of acylhomoserinlactone - a kind of signaling molecule required for the development of biofilm (Khan et al., 2016). It is possible that our B. velezensis NUChC C1 and NUChC C2b strains also have the ability to quench the quorum sensing, because, despite the antibiofilm-forming properties of SRB biofilms, their antagonistic properties against these bacteria have not been noted.

In addition, representatives of $B$. velezensis are producers of bacillibactin (Rabbee et al., 2019) - a siderophore of the catecholate type (Hertlein et al., 2014). The ability to form bacillibactin is also the characteristic of our studied strains of $B$. velezensis NUChC C1 and NUChC C2b. Siderophores are low molecular weight compounds that chelate $\mathrm{Fe}^{3+}$ ions, convert iron bound to proteins or waterinsoluble compounds into an ionic form of $\mathrm{Fe}^{3+}$ available to microorganisms (Leonov et al., 2016).

A number of researchers point to the fact that iron (III) plays an important role in the formation of microbial biofilms, and the depletion of iron in the environment can slow down the formation of biofilms (Harrison \& Buckling, 2009; Cai et al., 2010; Glick et al., 2010; Pelchovich et al., 2013; Ali \& Wakte, 2016). Analyzing recent publications, Rizzi et al. (Rizzi et al., 2019) conclude that biofilm formation and Fe uptake are closely related, and that biofilm formation may play an important mechanistic role in Fe uptake by siderophore in biofilm-forming bacteria. Harrison and Buckling showed (Harrison \& Buckling, 2009) that clones of Pseudomonas aeruginosa which were defected from cooperative production of iron-scavenging siderophores were deficient in biofilm formation. The presence of such clones in mixed biofilms with a wild-type clone led to reduced biofilm mass (Harrison \& Buckling, 2009). Researchers noted (Ali \& Wakte, 2016) that the supply of sufficient iron by siderophore insists the strain to form strong biofilm.
While the strain produce low to moderate amount of siderophore shown weak biofilm formation. This reveals that low amount of siderophore insufficient to transport optimum iron for growth and biofilm development under iron restricted condition (Ali \& Wakte, 2016). Along with this it is noted that the biofilm formation and development are strongly dependent on iron availability, and, for this reason, iron chelation may be an encouraging and novel approach to control biofilm (Ribeiro \& Simões, 2019). The antibacterial activity may be achieved by the ability of non-metabolizable iron chelators to diminish iron that could otherwise be used for bacterial replication. Very effective chelators may deprive pathogenic microorganisms of the iron essential for growth. Thus, iron chelators can be used as therapeutic compounds (Ribeiro \& Simões, 2019).

\section{Conclusions}

NUChC $\mathrm{C} 1$ and NUChC C2b isolates from the collection of the Department of Biology of the T.H. Shevchenko National University "Chernihiv Colehium" belong to different strains, have the presence and different transcriptional activity of genes of bacillibactin synthesis operon, and, accordingly, different production of siderophore bacillibactin. According to the complex of microbiological and genetic traits, the studied bacteria were identified as Bacillus velezensis. The siderophore-producing Bacillus velesensis strains inhibit the formation of sulfate-reducing bacteria biofilms on the polymeric material poly(ethylene terephthalate) with its long-term exposure (50 days) in a culture of bacteria under conditions of sufficient iron supply. Antagonistic properties of the studied strains against sulfate-reducing bacteria $D$. oryzae NUChC SRB1 and D. oryzae NUChC SRB2 were not observed.

Bacillibactin-producing strains prevent the development of bacterial biofilms on the poly(ethylene terephthalate) surface. This is one of the reasons for the prolongation of the process of poly(ethylene terephthalate) biodegradation in natural ecosystems.

\section{Acknowledgements}

We are sincerely grateful to the leading engineer Volodymyr Strekalov (Institute of agricultural microbiology and agroindustrial production of National Academy of agricultural sciences of Ukraine) for carrying out of electronic microscopy, the students Vladyslava Kikhtenko and Anastasiya Samkova (T.H. Shevchenko National University "Chernihiv Colehium") for excellent technical assistance. 


\section{References}

Abe T., Kobayashi K., Kawamura Sh., Sakaguchi T., Shiiba K. \& Kobayashi M., 2019, Dipeptide synthesis by internal adenylation domains of a multidomain enzyme involved in nonribosomal peptide synthesis. The Journal of General and Applied Microbiology 65(1): 1-10. doi: 10.2323/jgam.2018.03.001

Aïmeur N., Houali K., Hamadou L., Benbrahim N. \& Kadri A., 2015, Influence of strain Bacillus cereus bacterium on corrosion behaviour of carbon steel in natural sea water. The International Journal of Corrosion Processes and Corrosion Control, 50(8): 579-588. doi:10.1179/17 43278215Y.0000000022

Ali S.S. \& Wakte P.S., 2016, Biofilm formation and siderophore production by Pseudomonas Aeruginosa isolated from wounds infection. International Journal of New Technology and Research 2(9): 20-23.

Andrushkiv B., Vovk I. \& Pohaidak O., 2012, Udoskonalennia ekonomichnoho instrumentariiu poshuku novykh resursiv $\mathrm{v}$ umovakh postradianskoho suspilstva [Improving the economic tools for finding new resources in post-Soviet society]. Halytskyi Ekonomichnyi Visnyk 3(36). (in Ukrainian)

Bano A.Sh. \& Qazi J.I., 2011, Soil Buried Mild Steel Corrosion by Bacillus cereus-SNB4 and its Inhibition by Bacillus thuringiensis-SN8. Pakistan Journal of Zoology 43(3): 555-562.

Bhinu V.S., 2005, Insight into biofilm-associated microbial life. Journal of Molecular Microbiology and Biotechnology 10: 15-21. doi: 10.1159/000090344

Burak O.M. \& Kyrychenko A.Iu., 2020, Stvorennia punktiv pryiomu PET-pliashok dlia udoskonalennia protsesu upravlinnia vidkhodamy $\mathrm{v}$ Ukraini [A creative point for receiving PET bottles to improve the waste management process in Ukraine]. Materialy Mizhnarodnoi naukovo-praktychnoi internet-konferentsii "Pidpryiemnytstvo ta biznes-administruvannia”, m. Kharkiv, 2020. (in Ukrainian)

Cai Y., Wang R., An M.-M. \& Liang B.-B., 2010, Irondepletion prevents biofilm formation in Pseudomonas aeruginosa through twitching mobility and quorum sensing. Brazilian Journal of Microbiology 41(1): 3741. doi: $10.1590 / \mathrm{S} 1517-83822010000100008$

Chen Zh., Wang Y., Cheng Y., Wang X., Tong S., Yang H. \& Wang Z., 2020, Efficient biodegradation of highly crystallized polyethylene terephthalate through cell surface display of bacterial PETase. Science of The Total Environment 709: 136138. doi: 10.1016/j.scitotenv.2019.136138

De Vos P., Garrity G.M., Jones D., Krieg N.R., Ludwig W., Rainey F.A., Schleifer K.-H. \& Whitman W.B. (eds.), 2009, The Firmicutes, 2nd ed., Vol. 3. Bergey's Manual of Systematic Bacteriology. Springer, New York, NY, USA.

Dikiy I.L., Holupyak I.Y. \& Sidorchuk I.I., 2002, Mikrobiologiya. Rukovodstvo k laboratornyim zanyatiyam [Microbiology. A guide to laboratory exercises]. Izdatel'stvo Nacional'nogo farmacevticheskogo universiteta “Zolotye stranicy", Har'kov, 444 pp. (in Russian)

Du J., Li S., Liu J. \& Yu M., 2014, Corrosion behavior of steel Q235 co-influenced by Thiobacillus thiooxidans and Bacillus. Journal of Beijing University of Aeronautics and Astronautics 40(1): 31-38.

Dunlap Ch.A., Kim S.-J., Kwon S.-W. \& Rooney A.P., 2016, Bacillus velezensis is not a later heterotypic synonym of Bacillus amyloliquefaciens; Bacillus methylotrophicus, Bacillus amyloliquefaciens subsp. plantarum and 'Bacillus oryzicola' are later heterotypic synonyms of Bacillus velezensis based on phylogenomics. International Journal of Systematic and Evolutionary Microbiology 66: 1212-1217. doi: 10.1099/ijsem.0.000858

Egorov N.S., 1965, Mikrobyi antagonistyi i biologicheskie metodyi opredeleniya antibioticheskoy aktivnosti [Microbes antagonists and biological methods for determining antibiotic activity]. Vysshaya Shkola, Moskva, 211 pp. (in Russian)

Filella M., 2020, Antimony and PET bottles: Checking facts. Chemosphere 261: 127732. doi: 10.1016/j.chemosphere.2020.127732

Glick R., Gilmour C., Tremblay J., Satanower S., Avidan O, Déziel E., Greenberg E.P., Poole K. \& Banin E., 2010, Increase in rhamnolipid synthesis under iron-limiting conditions influences surface motility and biofilm formation in Pseudomonas aeruginosa. Journal of Bacteriology 192(12): 2973-80. doi: 10.1128/JB.01601-09

Grabova A.Yu., Dragovoz I.V., Zelena L.B., Tkachuk D.M. \& Avdeeva L.V., 2016, Antifungal activity and gene expression of lipopeptide antibiotics in strains of $\mathrm{Ba}$ cillus genus. Biopolymers and Cell 32(1): 41-48. doi: 10.7124/bc.00090B

Harrison F. \& Buckling A., 2009, Siderophore production and biofilm formation as linked social traits. The ISME Journal 3:632-634. doi: 10.1038/ismej.2009.9

Hertlein G., Müller S., Garcia-Gonzalez E., Poppinga L., Süssmuth R. D. \& Genersch E., 2014, Production of the catechol type siderophore bacillibactin by the honey bee pathogen Paenibacillus larvae. PloS One 9(9): e108272. doi:10.1371/journal.pone.0108272

Hsueh Y.-H., Huang K.-Y., Kunene S.Ch. \& Lee T.-Y., 2017, Poly- $\gamma$-glutamic acid synthesis, gene regulation, phylogenetic relationships, and role in fermentation, International Journal of Molecular Sciences 18: 2644. doi: 10.3390/ijms18122644

Jayaraman A., Hallock P.J., Carson R.M., Lee C.C., Mansfeld F.B. \& Wood T.K., 1999a, Inhibiting 
sulfate-reducing bacteria in biofilms on steel with antimicrobial peptides generated in situ. Applied Microbiology and Biotechnology 52: 267-275. doi: 10.1007/s002530051520

Jayaraman A., Mansfeld F.B. \& Wood T.K., 1999b, Inhibiting sulfate-reducing bacteria in biofilms by expressing the antimicrobial peptides indolicidin and bactenecin. Journal of Industrial Microbiology and Biotechnology 22: 167-175. doi: 10.1038/sj.jim.2900627

Khan R., Shen F., Khan K., Liu L.X., Wu H.H., Luo J.Q. \& Wan Y.H., 2016, Biofouling control in membrane filtration system by newly isolated novel quorum quenching bacterium, Bacillus methylotrophicus sp. WY. RSC Advances 6: 28895-28903. doi: 10.1039/C6RA01663D

Korenblum E., Sebastián G.V., Paiva M.M., Coutinho C.M.L.M., Magalhães F.C.M., Peyton B.M. \& Seldin L., 2008, Action of antimicrobial substances produced by different oil reservoir Bacillus strains against biofilm formation. Applied Microbiology and Biotechnology 79: 97-103. doi: 10.1007/s00253-008-1401-x

Korenblum E., de Araujo L.V., Guimaraes C.R., de Souza L.M., Sassaki G., Abreu F., Nitschke M., Lins U., Freire D.M.G., Barreto-Bergter E. \& Seldin L., 2012, Purification and characterization of a surfactin-like molecule produced by Bacillus sp. H2O-1 and its antagonistic effect against sulfate reducing bacteria. BMC Microbiology 12: 252-264. doi: 10.1186/1471-2180-12-252

Leonov V.V., Mironov A.Yu., Ananina I.V., Rubalskaya E.E. \& Sentyurova L.G., 2016, Mikrobnye siderofory: struktura, svojstva, funkcii [Siderophores of microbes: structure, properties and functions]. Astrahanskiy Meditsinskiy Zhurnal 11(4): 24-37. (in Russian)

Livak K.J. \& Schmittgen T.D., 2001, Analysis of relative gene expression data using real-time quantitative PCR and the $2^{-\triangle \Delta C T}$ method. Methods 25: 402-408. doi: $10.1006 /$ meth.2001.1262

Lukash O.V., 2015, Stykhiini smittiezvalyshcha v okolytsiakh silskykh naselenykh punktiv Chernihivshchyni: vplyv na pryrodni ekosystemy ta sotsialnyi aspekt problem [Spontaneous landfills in the vicinity of rural settlements in Chernihiv region: impact on natural ecosystems and the social aspect of the problem], Formuvannia stratehii povodzhennia $\mathrm{z}$ vidkhodamy $\mathrm{v}$ umovakh detsentralizatsii vlady: problemy ta perspektyvy realizatsii na rivni mistsevykh hromad: zbirka materialiv natsionalnoho forumu "Povodzhennia z vidkhodamy v Ukraini: zakonodavstvo, ekonomika, tekhnolohii" (10-11 lystopada 2015 r., m. Kyiv). Tsentr ekolohichnoi osvity ta informatsii, Kyiv, p. 66-68. (in Ukrainian)

Mongkolthanaruk W., 2012, Classification of Bacillus Beneficial Substances Related to Plants, Humans and Animals. Journal of Microbiology and Biotechnology 22(12): 1597-1604. doi: 10.4014/jmb.1204.04013
NCBI, 2019, Taxonomy [online]. Website https://www. ncbi.nlm.nih.gov/Taxonomy/ [accessed 15 November 2019]

Ornek D., Jayaraman A., Syrett B.C., Hsu C.H., Mansfeld F.B. \& Wood T.K., 2002, Pitting corrosion inhibition of aluminum 2024 by Bacillus biofilms secreting polyaspartate or g-polyglutamate. Applied Microbiology and Biotechnology 58: 651-657. doi: 10.1007/s00253-002-0942-7

Pelchovich G., Omer-Bendori S. \& Gophna U., 2013, Menaquinone and iron are essential for complex colony development in Bacillus subtilis. PLoS One 8: e79488. doi: 10.1371/journal.pone.0079488

Qin Y., He Y., She Q., Larese-Casanova Ph., Li P., Li P. \& Chai Y., 2019, Heterogeneity in respiratory electron transfer and adaptive iron utilization in a bacterial biofilm. Nature Communications 10: 3702. doi: 10.1038/ s41467-019-11681-0

Rabbee M.F., Ali Md.S., Choi J., Hwang B.S., Jeong S.Ch. \& Baek K.-h., 2019, Bacillus velezensis: A Valuable Member of Bioactive Molecules within Plant Microbiomes. Molecules 24: 1046. doi:10.3390/molecules 24061046

Ramlucken U., Roets Y., Ramchuran S.O., Moonsamy G., van Rensburg Ch.J., Thantsh M.S. \& Lalloo R., 2020, Isolation, selection and evaluation of Bacillus spp. as potential multi-mode probiotics for poultry. The Journal of General and Applied Microbiology, Article ID 2019.11.002. doi: 10.2323/jgam.2019.11.002

Ribeiro M. \& Simões M., 2019, Siderophores: a novel approach to fight antimicrobial resistance, [in:] D. Arora, Ch. Sharma, S. Jaglan, E. Lichtfouse (eds.), Pharmaceutical from microbes: impact on drug discovery. Springer International Publishing, p. 99-120.

Rizzi A., Roy S., Bellenger J.-Ph. \& Beauregard P.B., 2019, Iron Homeostasis in Bacillus subtilis Requires Siderophore Production and Biofilm Formation. Applied and Environmental Microbiology 85(3): e0243918. doi: 10.1128/AEM.02439-18

Rogers K.L., Carreres-Calabuig J.A., Gorokhova E. \& Posth N.R., 2020, Micro-by-micro inretactions: How microorganisms influence the fate of marine microplastics. Limnology and Oceanography Letters 5: 18-36. doi:10.1002/lol2.10136

Saha M., Sarkar S., Sarkar B., Sharma B.K., Bhattacharjee S. \& Tribedi P., 2016, Microbial siderophores and their potential applications: a review. Environmental Science and Pollution Research International 23(5): 3984-99. doi: 10.1007/s11356-015-4294-0.

Saveliev Yu.V., Yanovych I.V., Akhranovych O.R. et al., 2011, Stvorennia ta zastosuvannia dehraduiuchykh za umov navkolyshnoho seredovyshcha poliuretaniv na osnovi vuhlevodiv [Creation and application of polyurethanes, degrading under environmental conditions, 
based on carbohydrates], Polimernyi Zhurnal, 33(3): 205-217. (in Ukrainian)

Saxena A.K., Kumar M., Chakdar H., Anuroopa N. \& Bagyaraj D.J., 2020, Bacillus species in soil as a natural resource for plant health and nutrition. Journal of $A p$ plied Microbiology 128(6): 1583-1594. doi: 10.1111/ jam.14506

Shulga N.V., Tkachuk N.V. \& Zelena L.B., 2020, Biodegradatsiya polietilentereftalatu [Biodegradation of polyethylene terephthalate], Krok u nauku: doslidzhennya u galuzi prirodnicho-matematichnih distsiplin ta metodik yih navchannya: Zbirnik tez dopovidey Vseukrayinskoyi naukovo-praktichnoyi konferentsiyi studentiv, aspirantiv i molodih uchenih (20 listopada 2020 r., m. Chernihiv). NUChK imeni T.H. Shevchenka, Chernihiv, p. 74-75. (in Ukrainian)

Stepanović S., Vuković D., Dakić I., Savić B. \& ŠvabićVlahović M., 2000, A modified microtiter-plate test for quantification of staphylococcal biofilm formation. Journal of Microbiological Methods 40: 175-179. doi:10.1016/s0167-7012(00)00122-6

Sujatha N. \& Ammani K., 2013, Siderophore production by the isolates of fluorescent Pseudomonas. International Journal of Current Research and Review 5(20): $1-7$.

Tamura K., Stecher G., Peterson D., Filipski A. \& Kumar S., 2013, MEGA6: Molecular Evolutionary Genetics Analysis Version 6.0. Molecular Biology and Evolution 30: 2725-2729. doi: 10.1093/molbev/mst197.

Tkachuk N., Zelena L., Mazur P. \& Lukash O., 2020, Genotypic, physiological and biochemical features of Desulfovibrio strains in a sulfidogenic microbial community isolated from the soil of ferrosphere. Ecological Questions 31(2): 79-88. doi:10.12775/EQ.2020.016

Tkachuk N.V., Zelena L.B., Parminska V.S., Yanchenko V.O. \& Demchenko A.M., 2017, Identyfikatsiia heterotrofnykh bakterii ferosfery gruntu ta yikh chutlyvist do pestytsydu linuron [Identification of heterotrophic bacteria isolated from soil ferrosphere and their sensitivity to the pesticide linuron]. Mikrobiolohichnyi Zhurnal 79(4): 75-87. doi: 10.15407/microbiolj79.04.075 (in Ukrainian)

Vague M., Chan G., Roberts C., Swartz N.A., \& Mellies J.L., 2019, Pseudomonas isolates degrade and form biofilms on polyethylene terephthalate (PET) plastic. bioRxiv, 647321. doi: 10.1101/647321.

Wadood H.Z., Rajasekar A., Ting Y.-P. \& Sabari A.N., 2015, Role of Bacillus subtilis and Pseudomonas aeruginosa on Corrosion Behaviour of Stainless Steel. Arabian Journal for Science and Engineering 40: 18251836. doi: 10.1007/s13369-015-1590-4

Wang L., Yu L. \& Lin C., 2019, Extraction of Protease Produced by Sea Mud Bacteria and Evaluation of Antifouling Performance. Journal of Ocean University of China (Oceanic and Coastal Sea Research) 18: 11391146. doi: 10.1007/s11802-019-3843-4

Yoo Y., Seo D.-H., Lee H., Cho E.-S., Song N.-E., Nam T.G., Nam Y.-D. \& Seo M.-J., 2019, Inhibitory effect of Bacillus velezensis on biofilm formation by Streptococcus mutans. Journal of Biotechnology 298: 57-63. doi: 10.1016/j.jbiotec.2019.04.009

Yoshida S., Hiraga K., Takehana T., Taniguchi I., Yamaji H., Maeda Y., Toyohara K., Miyamoto K., Kimura Y. \& Oda K., 2016, A bacterium that degrades and assimilates poly(ethylene terephthalate). Science 351(6278): 1196-1199. doi: 10.1126/science.aad6359

Zelena L., Gretsky I. \& Gromozova E., 2014, Influence of ultrahigh frequency irradiation on Photobacterium phosphoreum luxb gene expression. Central European Journal of Biology 9: 1004-1010. doi: 10.2478/s11535014-0347-5

Zvyagintsev G.D., Babieva I.P. \& Zenova G.M., 2005, Biologiya pochv [Biology of soils]. Izdatel'stvo Moskovskogo universiteta, Moskva, 445 pp. (in Russian) 